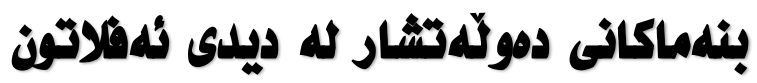

مسلم حسن محمدل

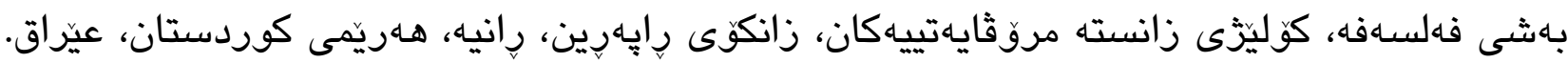

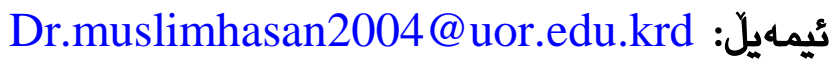

\section{زريان همزه عزيز}

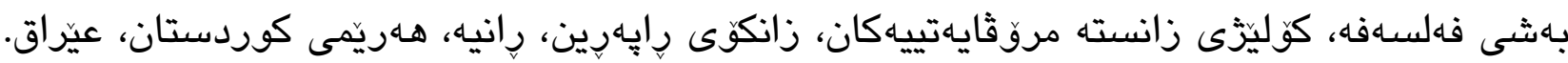
ئيميل: Zryan.hamzaaziz@uor.edu.krd

هوخته

هزرى سياسى ئهفلاتون و بنهماكانى يهكيكن لهو دهستكهوته كرنكانهى فهلسهفه شانازييان بيّوددهات، ئهو بنهما فهلسهفيانهى ئهفلاتون لهبوارى سياسيدا دايناون نمونهيهكى بالا له دهسهلاتى سياسى بيشاندهدهن و له له

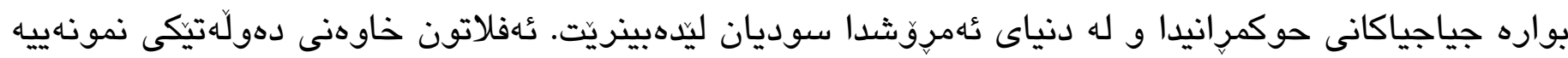

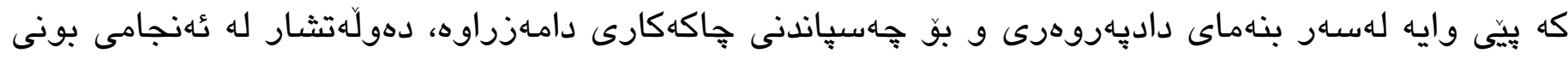

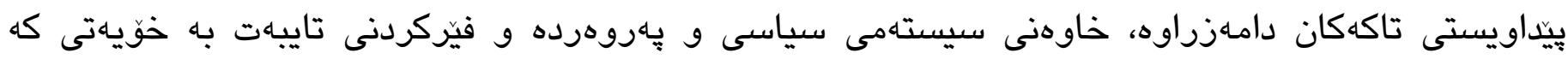
شافهيلهوف بهريّوهى دهبات. ئهفلاتون كَنكى زورى بهابوارى سياسى داوه به دارشتنى نهخشهيهكى كاريكهر و دروستكردنى شاره

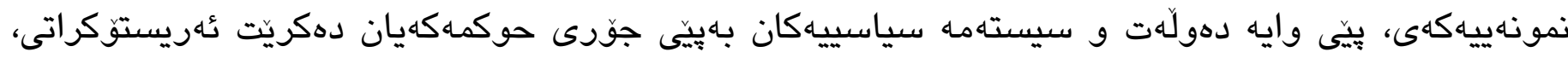

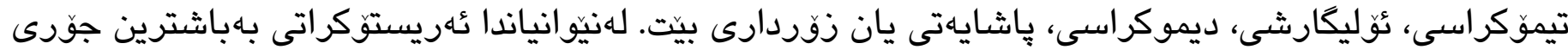

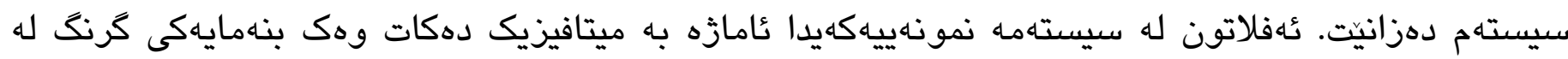

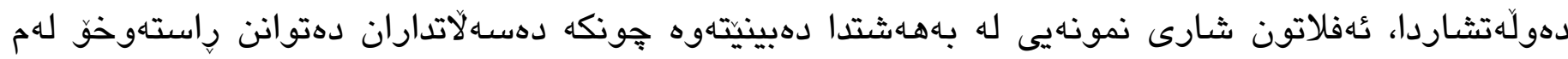

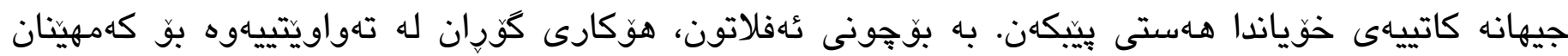

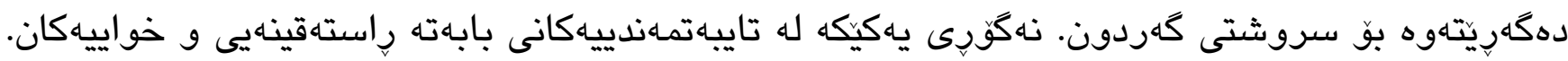

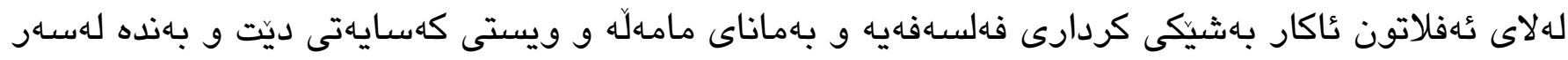

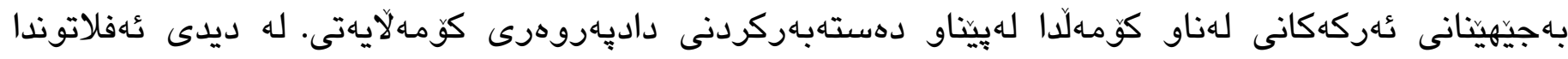

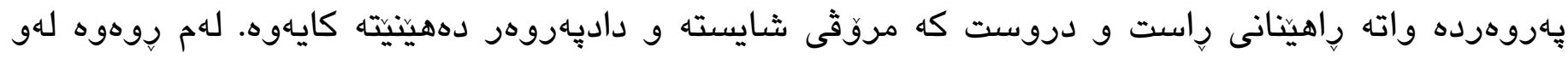

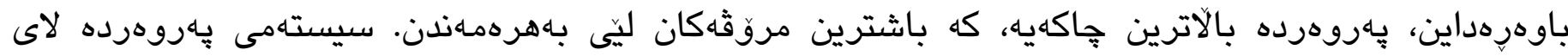

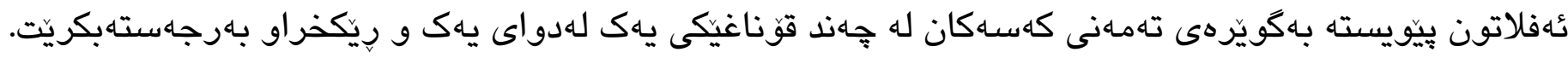

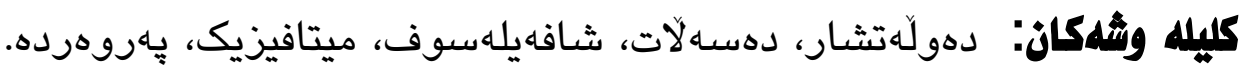




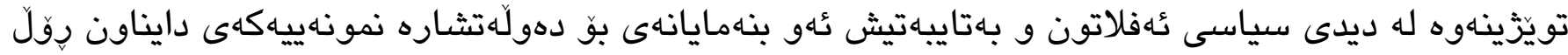

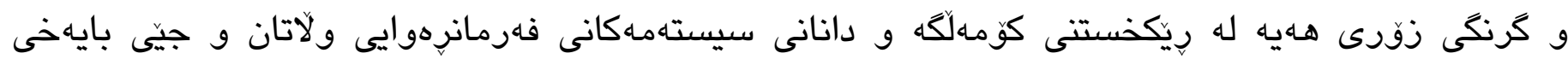

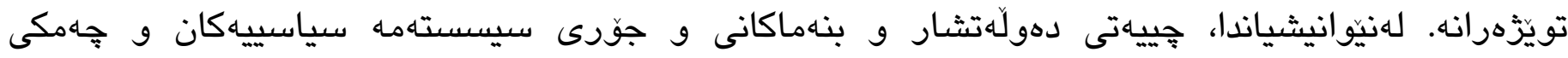
ميتافيزيك، هـروهها بِايوهندى نيّوان ئاكار و سياسهات لهلايهك و سيستهمى پِهروهرده و فيرّكردن لهلايهكى تر،

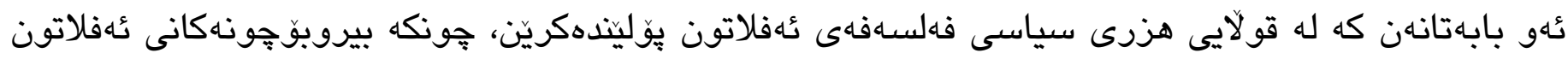

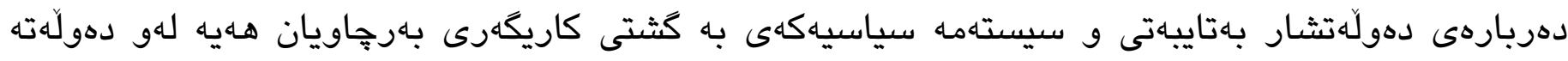

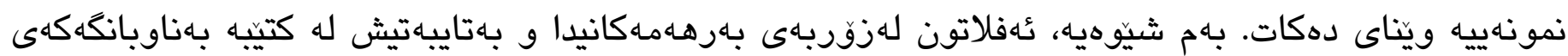

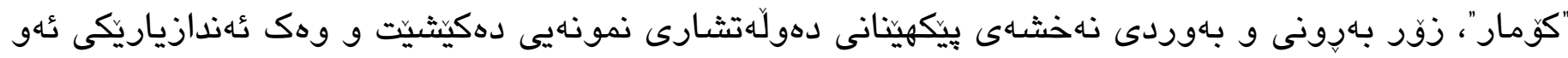

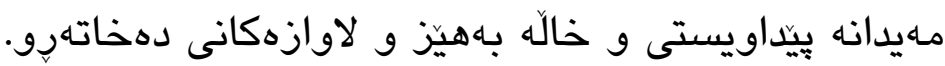

\section{كَرنكى تويَّرينهوه:}

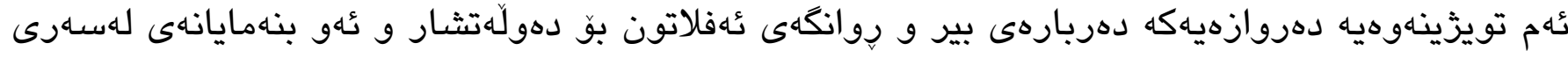

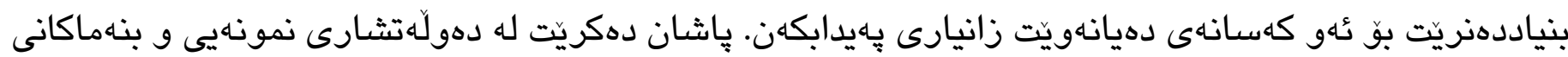

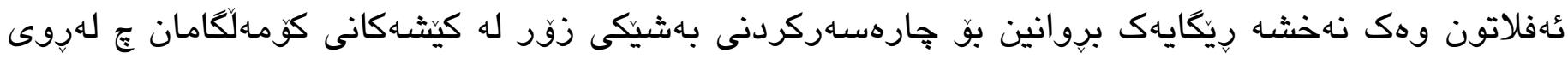

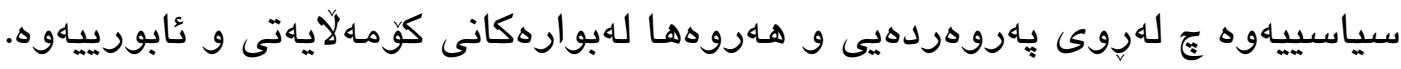

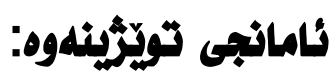

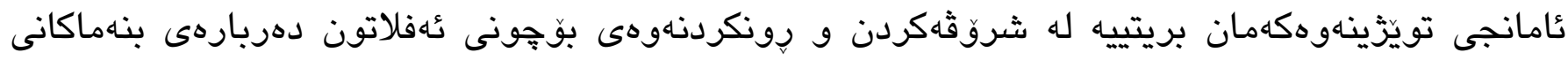

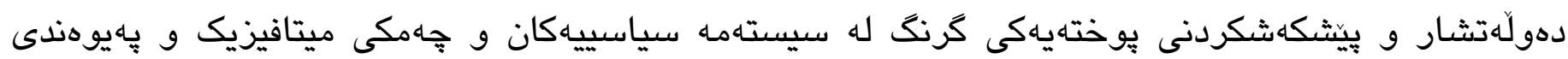

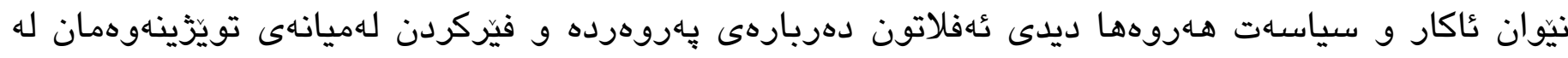
هزره فهلسهفييهكانى ئهفلاتون. ئامانجمانه خوينّهى كورد بهكثتى و بهتايبهتيش شهايدايانى فهلسهفهى ئهفلاتون،

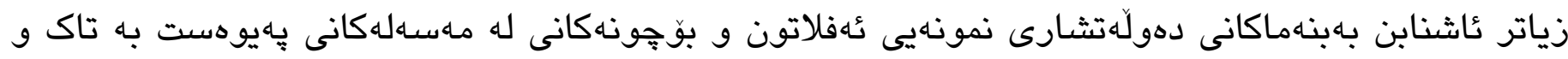

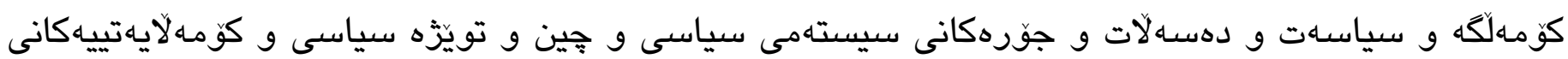
كومهالكه.

\section{يربيارمكانى تويَّينهوه:}

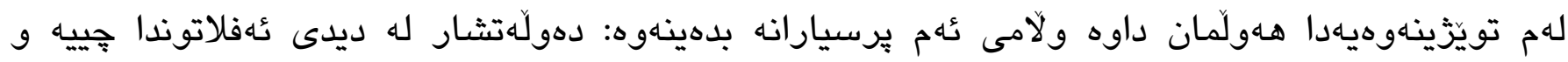

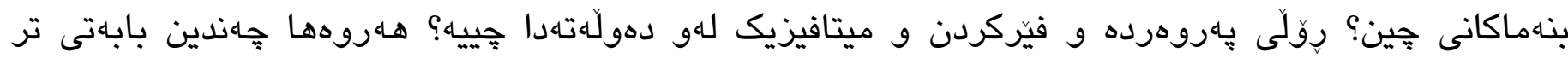
شروّثه و رِاثهكراوه له ميانى تويَزينهوهكهدا. 
لهبهرئهوهى ليكولَينهوه كراوه له بابهتى فهلسهفهى ئهفلاتون و لهبهر وردى و عاسان تينهكَهيشتن له بابهته

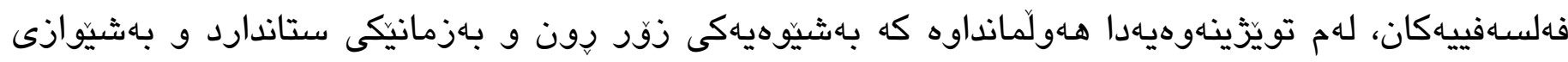

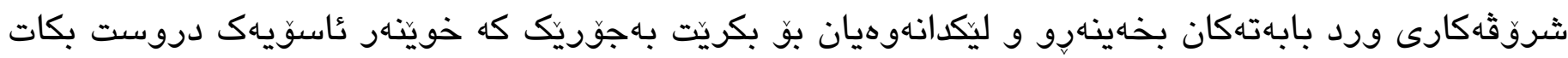
له فهلسهافهى ثٔهلاتون و ديده سياسيككهى.

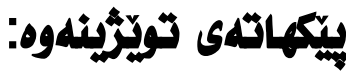

ناونيشانى تويَّزينهوهكه بريتييه له بنهماكانى دهولَهتشار له ديدى ئهفلاتون كه يِيكديّت له سيى باس. له باسى

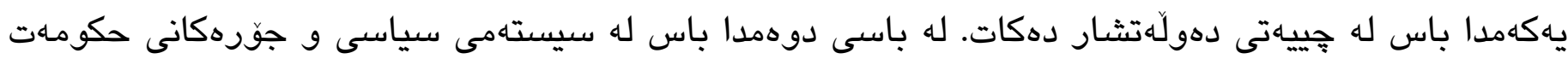

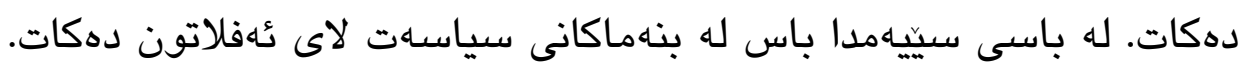

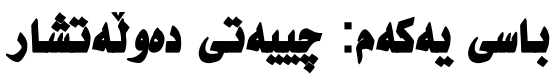

له سهردهمى ئهفلاتوندا دهولّهتشارهكان سنوريكى دياريكراويان هابو كه لهيهك شار و كوندهكانى

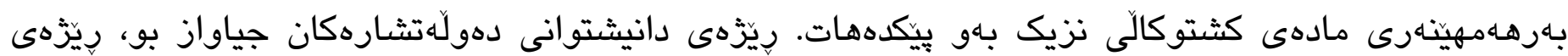

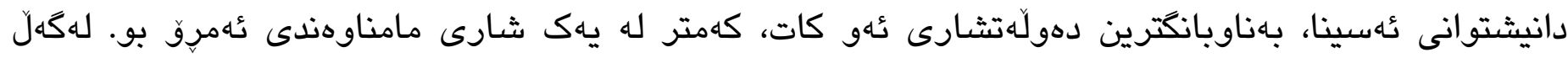

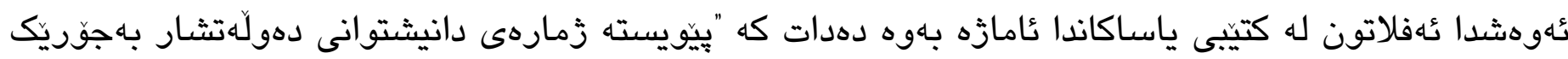

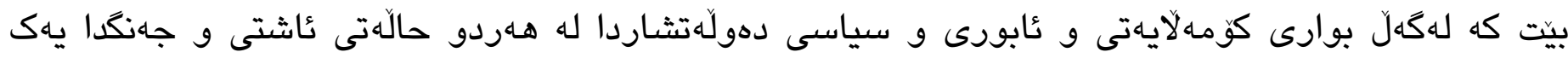

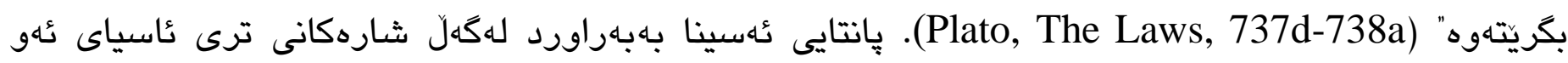

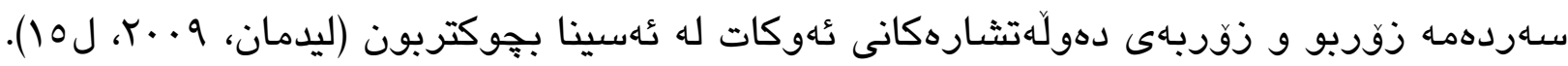

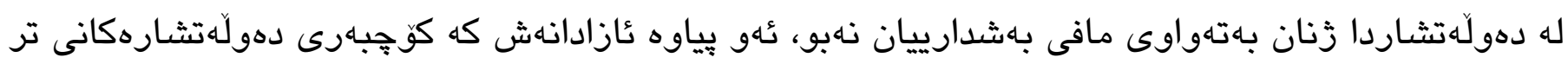

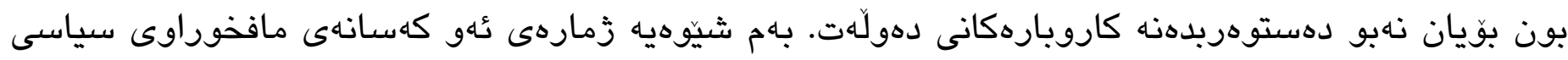

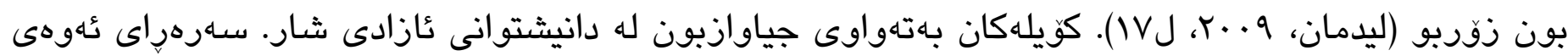

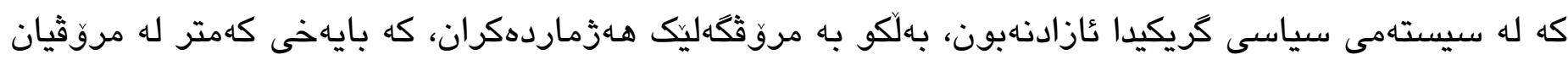

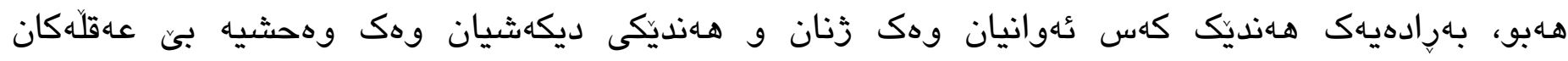
دهزانى(باربييه،

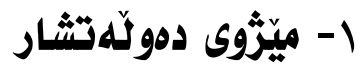

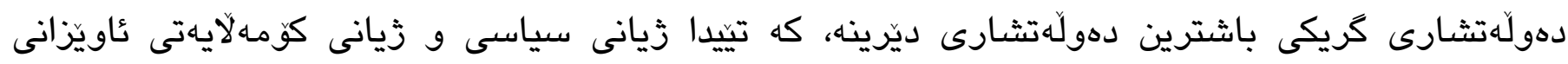

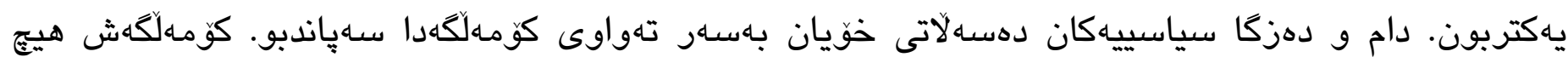




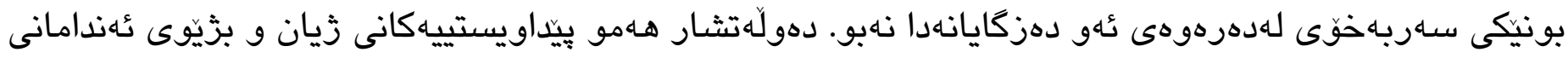

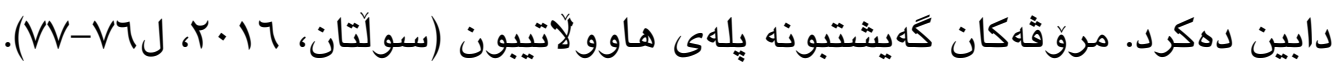

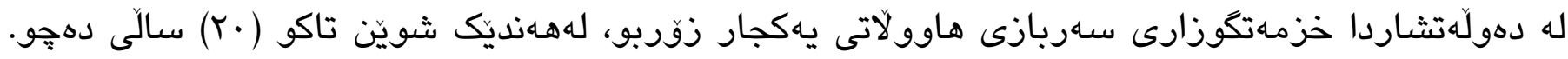

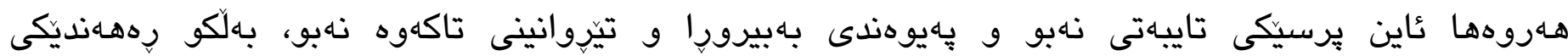

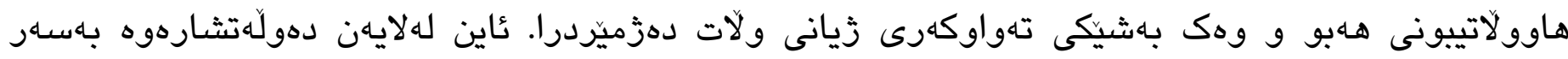

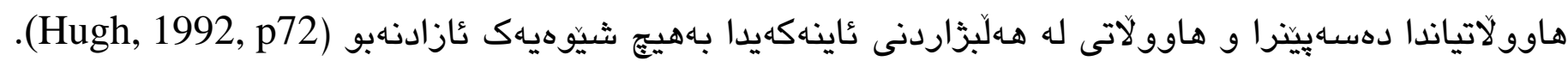

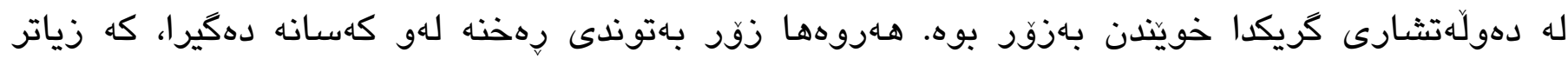
بايهخيان به زيانى تايبهتى خَّيان دهدا نهك كاروبارى كثتى. هاوولاتى لهبهر يهيوهستبونى به دهولَتشار،

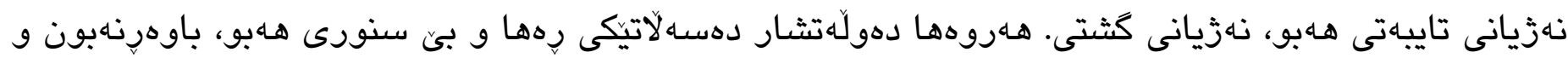

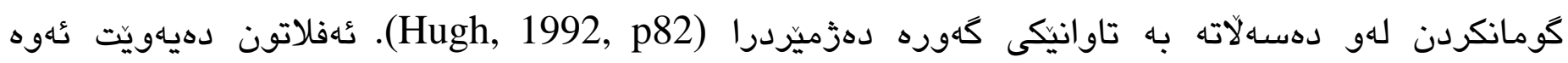

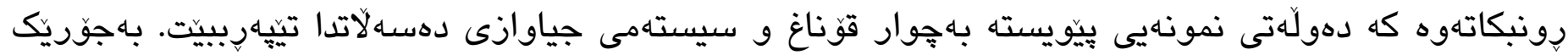

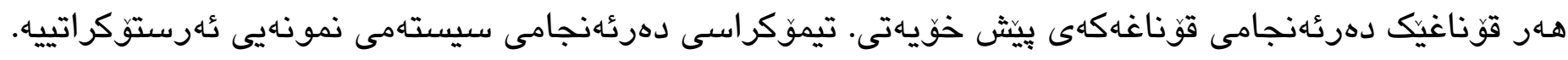
ئوليكارشى دهرهاويشتاهى سيستهمى تيموكراسى و ديموكراسى دهرئهنجامى سيستهى ئوليكارشى و زوردارى

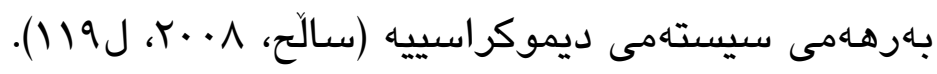

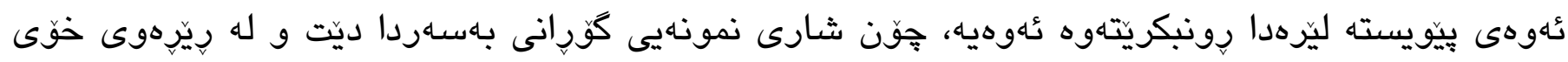

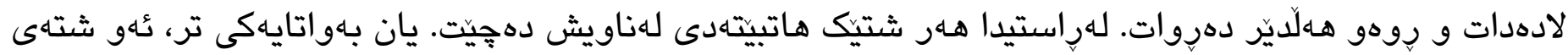

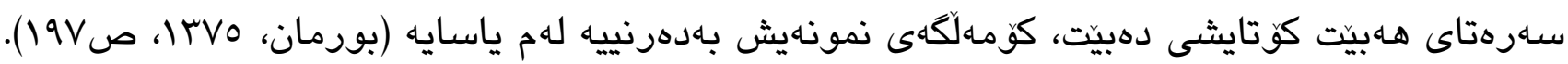

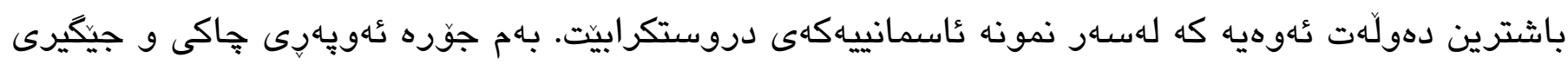

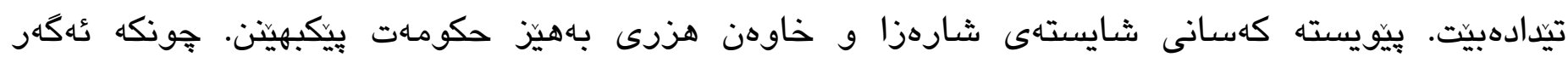

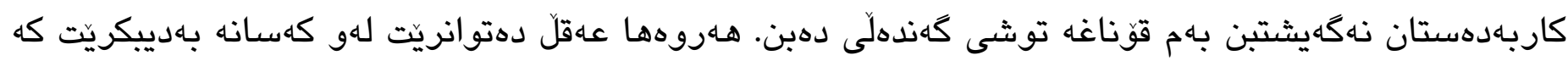

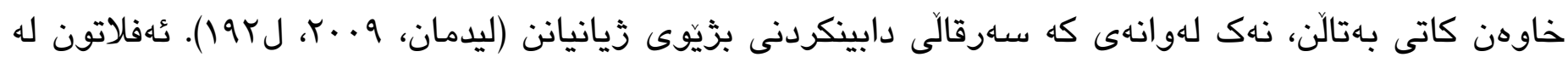

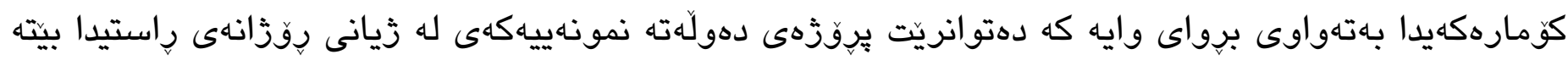

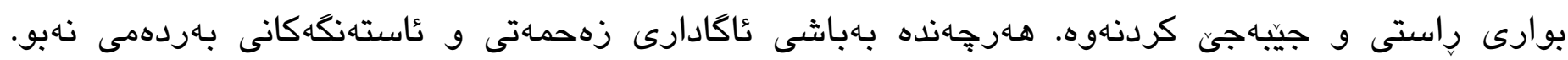

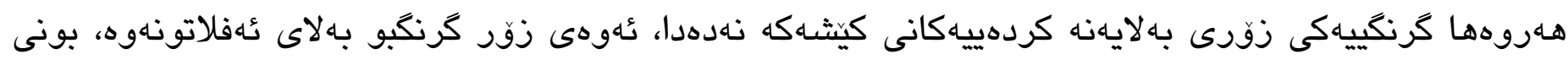

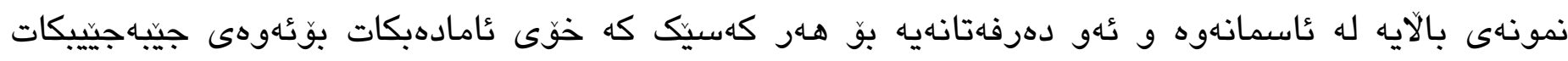

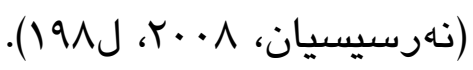

ديموكراسى بههـمو شيّوازهكانيهوه للهلايهن ئهلاتوناهوه بهاباشتر له سيستهمهانى زقوردارى دانراوه، كه له كتيّبى 'كومار'دا له سـروى ديموكراسييهوه داينابو. له كتيبيى سياسـاهمهداردا ئهفلاتون هيثتا لهو بروايهدايه كه تاكهكهـاكان كاملنين و ديموكراسى ئهو سيستهمهيه كه دهستبهرداربونى نييه و بهبحّ تُهو ناتوانريّت بهر لهو 


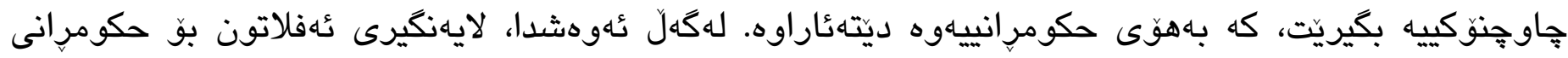
فهيلهسوفه داناكان له كتيبي 'سياسهتمهدار'دا هـستى بيّدهكريّت (Barker, 1960, p337).

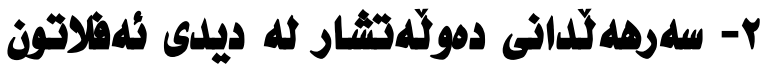

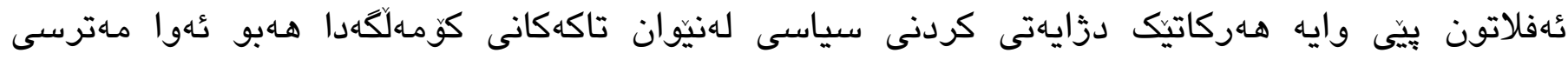

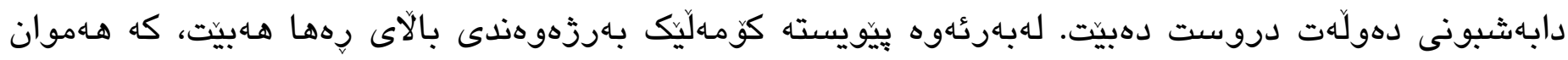

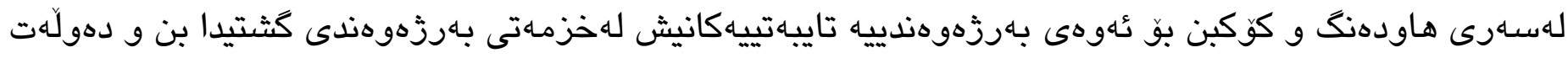

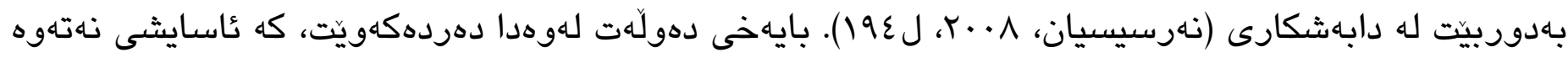

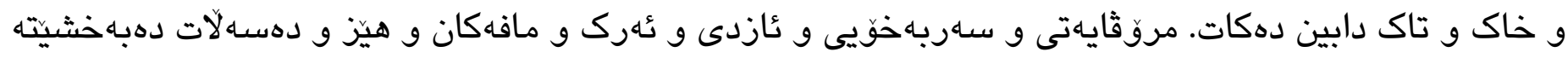

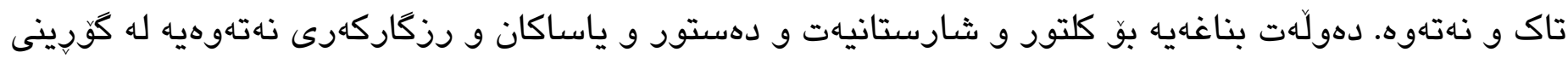

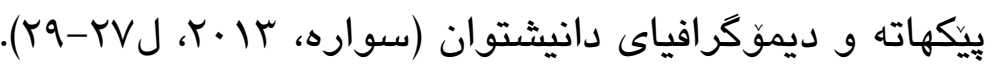

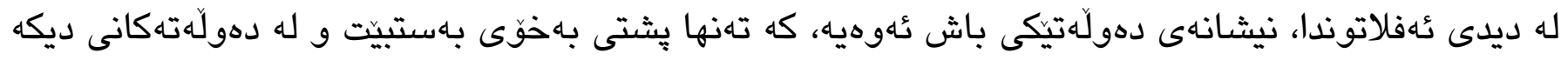

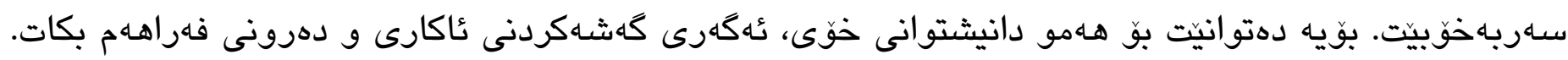

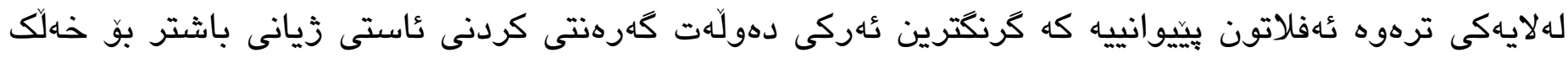

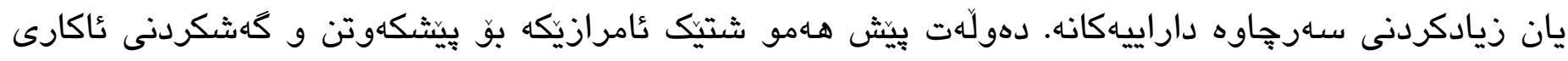

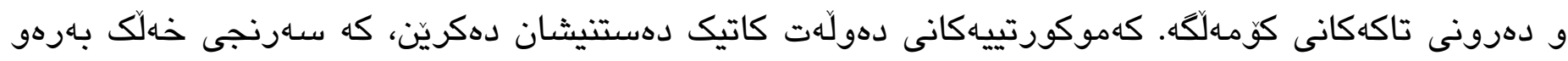

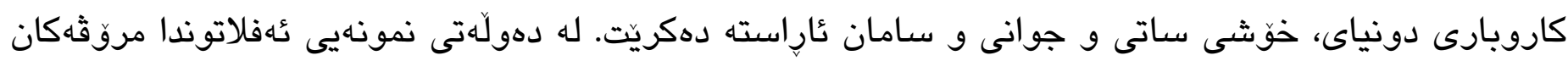

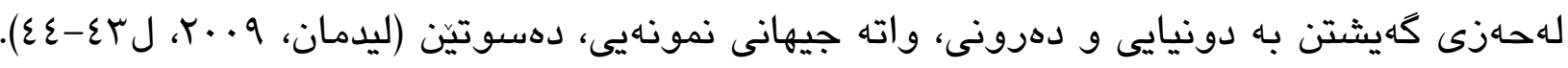

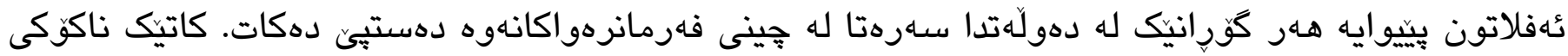

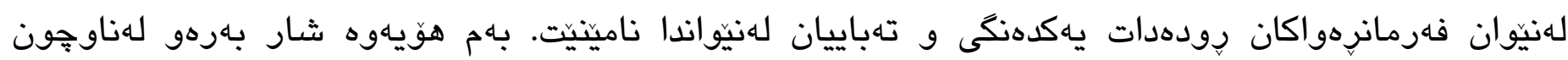

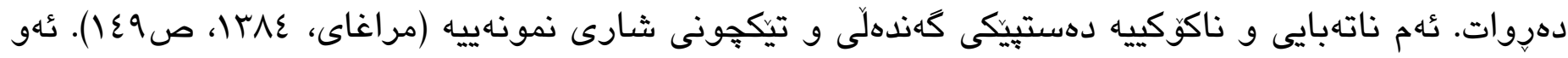

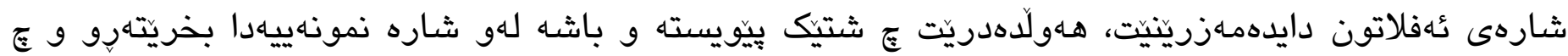

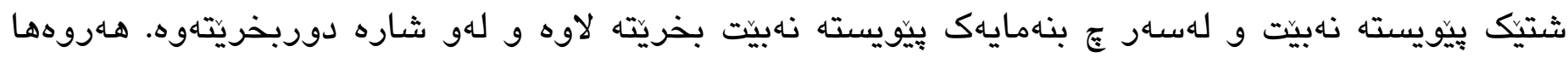

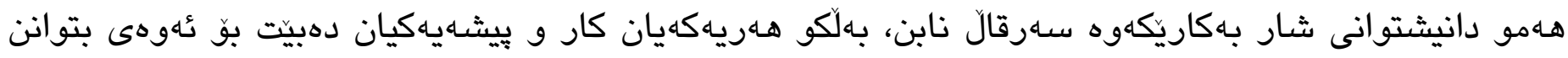

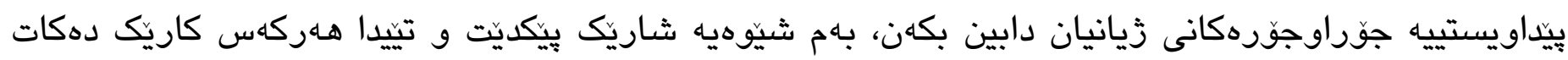

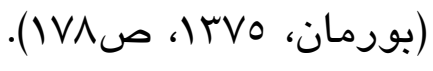

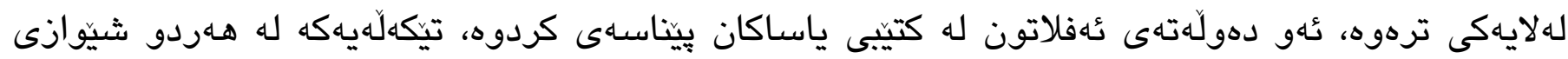

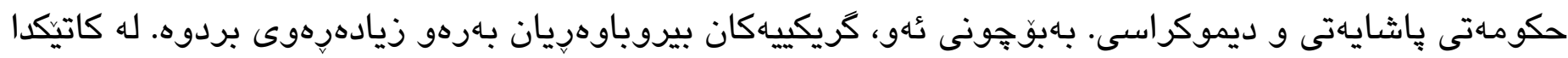

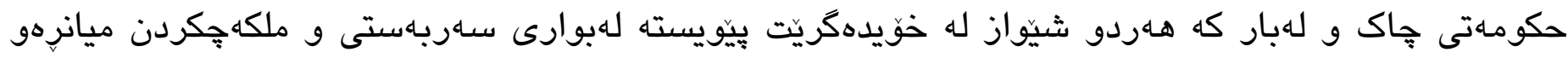


بيتت. هـار دهولَهتيك ياسـا تيّيدا سـهروهر بيتت و له سـرهوه بيّت و دهسهلآتدارهكانى نزمتر بن له ياسـا ئهوا ئهو

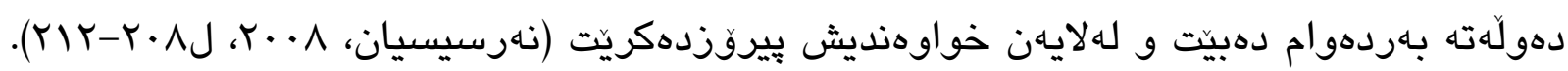

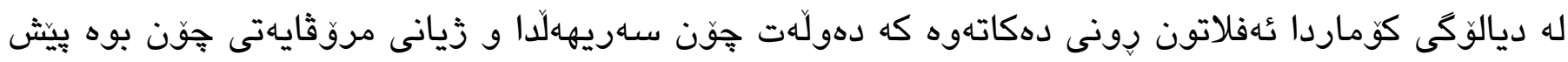

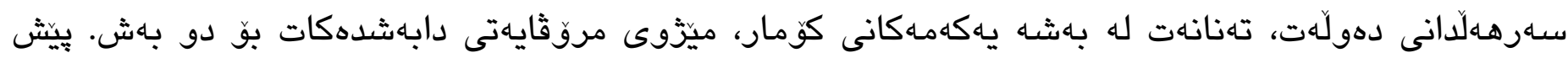

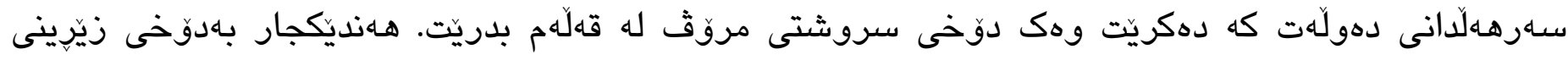

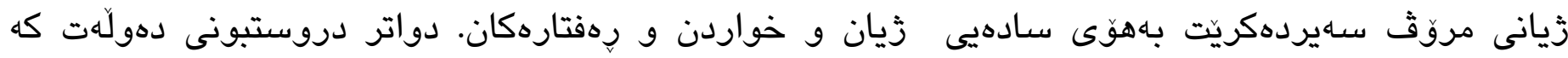

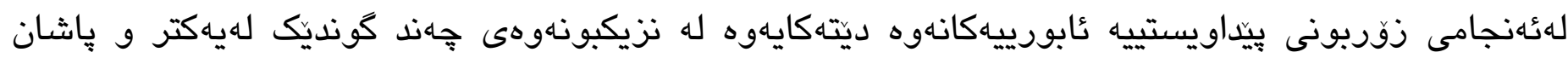

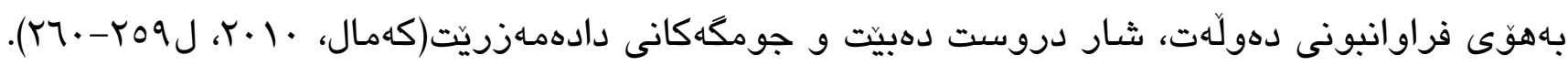

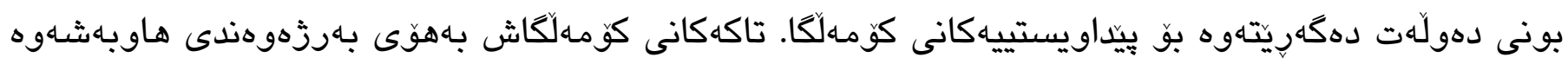

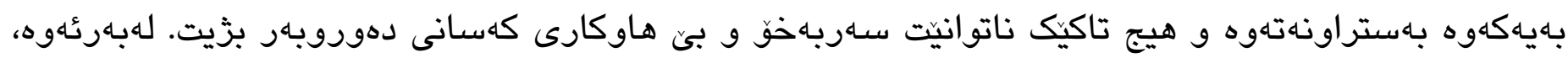

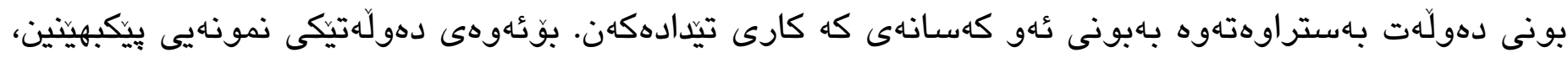

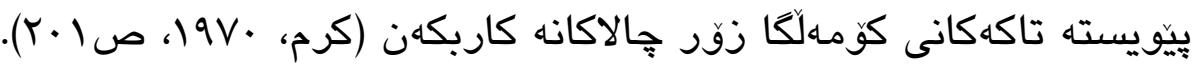

\section{ب- بنهماكانى دهولّهتثار}

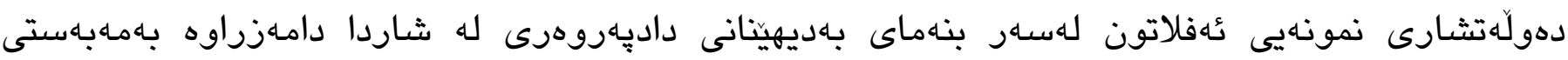
دروستكردنى دهولّتيكى نمونهيى. داديهروهريش له دهولَهى نمونهييدا بهدينايهت بهبئ بونى كارابونى هـرسيّ

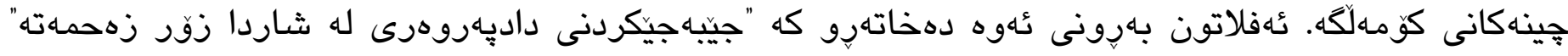

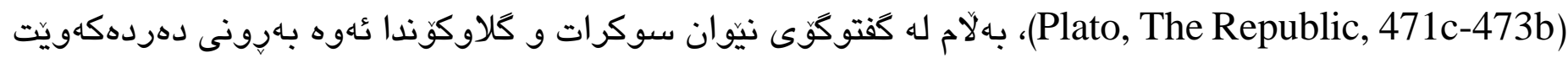

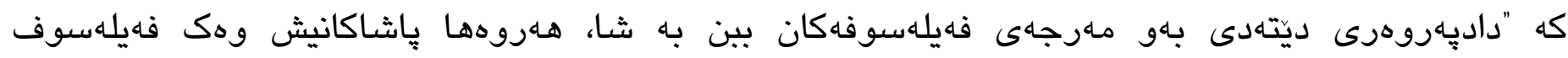
رهفتاربكهن" (Plato, The Republic, 473d). هـروهها ئهفلاتون ئامازّه بهوه دهدات، كه "داديهروهرى بهكَيّرهى Plato, The Republic, 338e- (سيستهمه سياسييهكان جياوازه و هـميشـه لهبهرزهوهندى به هيزهكان كاردهكات

.$(339 \mathrm{a}$

له كوماردا ئهفلاتون لهاسـر زارى سوكرات له سيّ رِوهوه باس لهباشى داديهروهرى دهكات بـسـار ناداديهروهريدا، يـكهم: "كهسى داديهروهر زيرهك و خاوهن جاكهيه، بهلاّم كهسى ناداديهروهر خراب و بيركولّه"

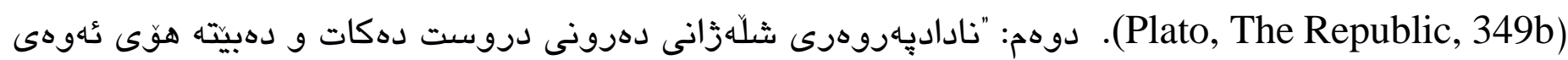

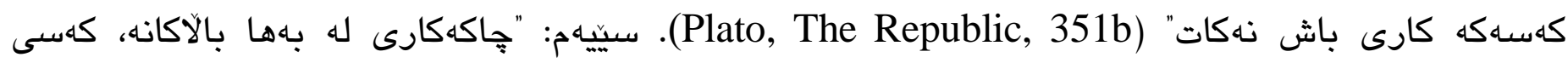
داديهروهر لهزيانيكى كامهراندا دهزيت، بهبهراورد له گلَ كهسى ناداديهروهر" (Plato, The Republic, 352d).

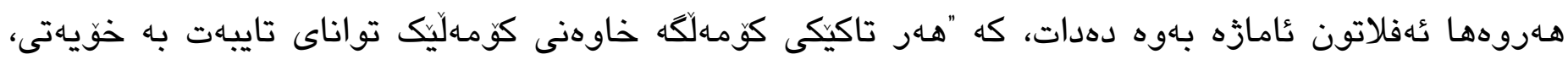

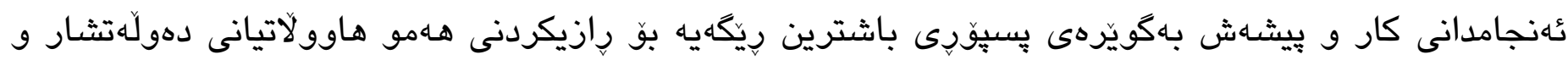

جهـسياندنى داديهروهرى" (Plato, The Republic, 370a-370c). 


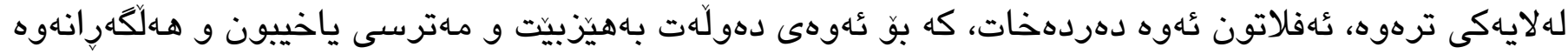

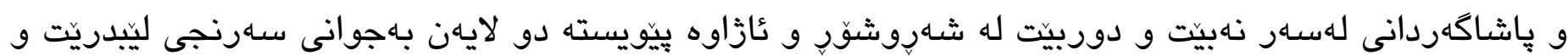

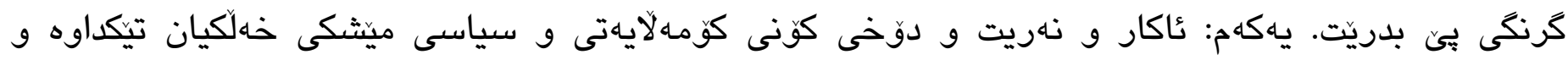

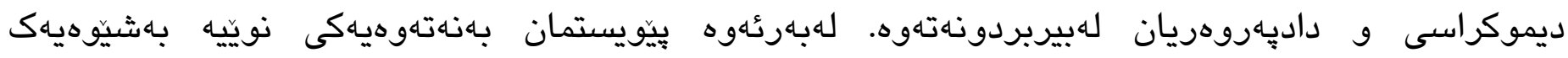

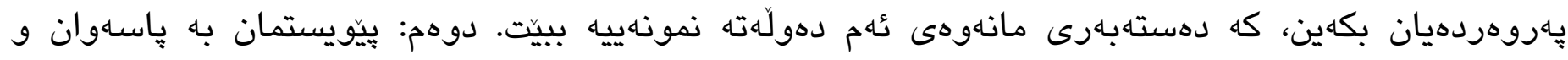

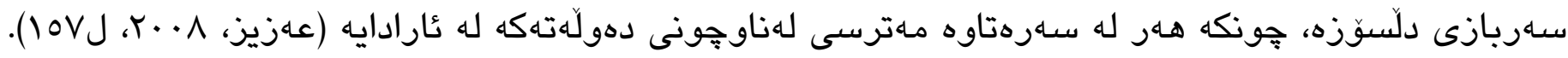

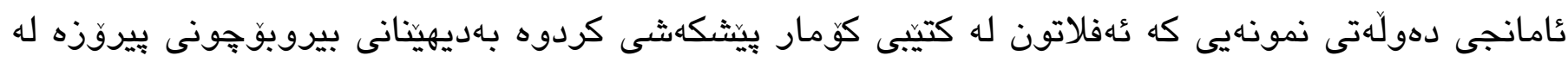

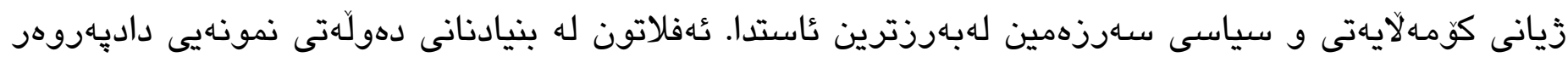
له جهامكى وهك يهكبونى نيّوان كَردون و دهولّت و روح له تاكيكى مروّايهتى دهست يِّدهكات و بيروّكى

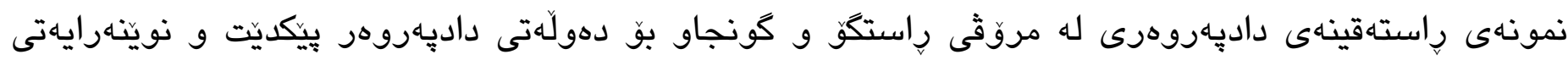

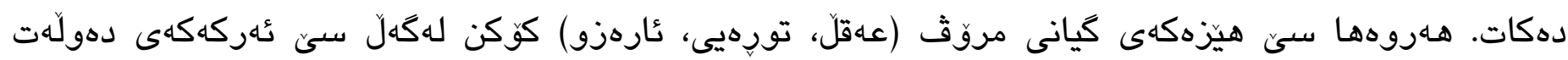

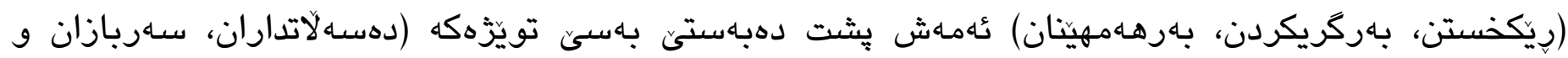

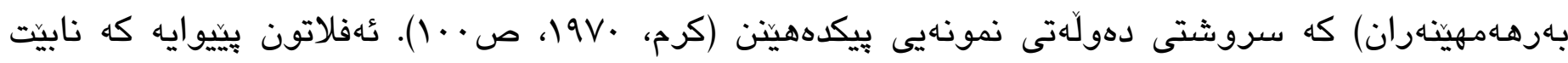

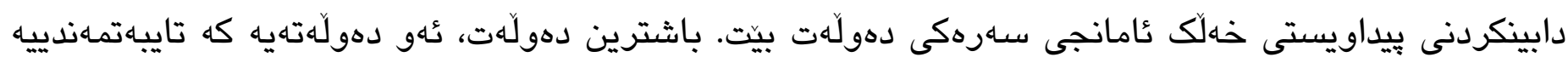

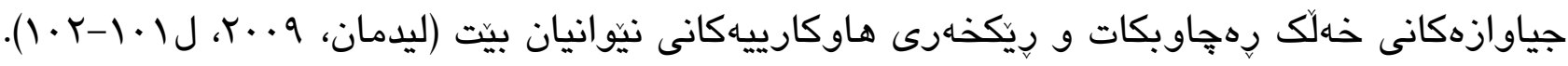

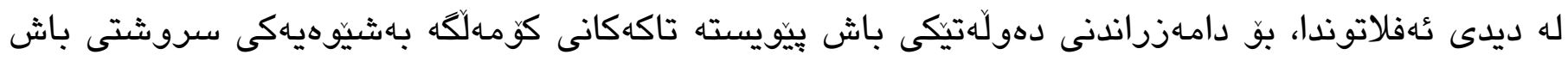

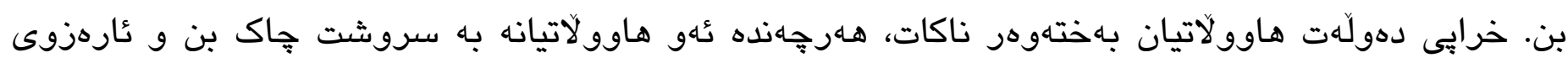

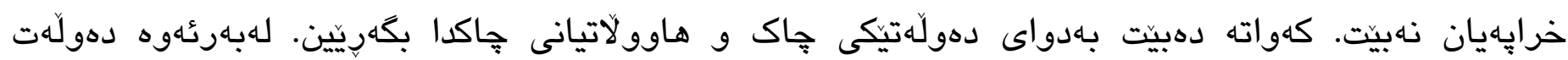

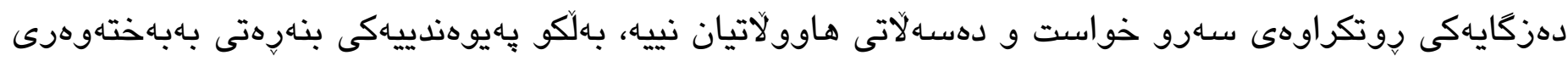

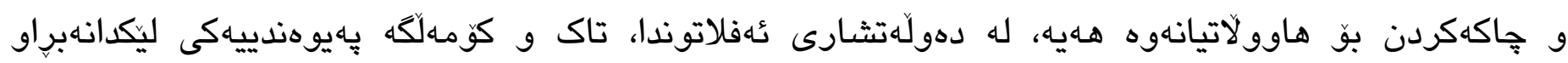

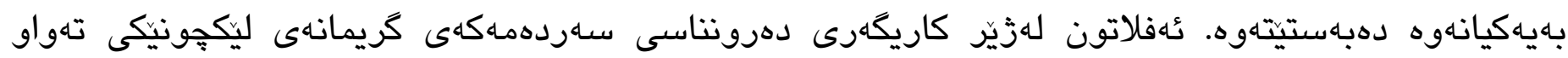

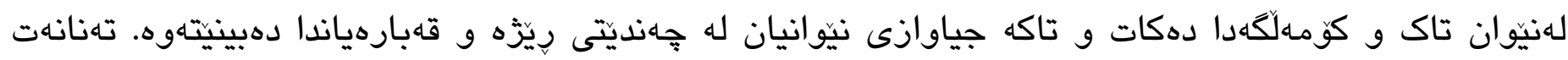

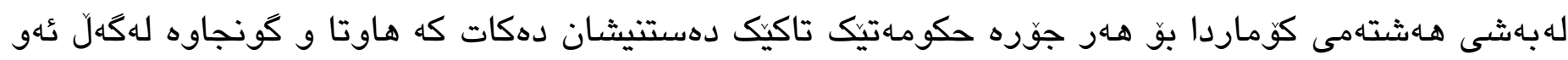

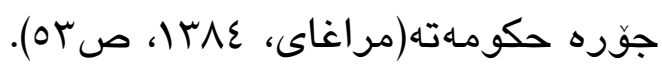

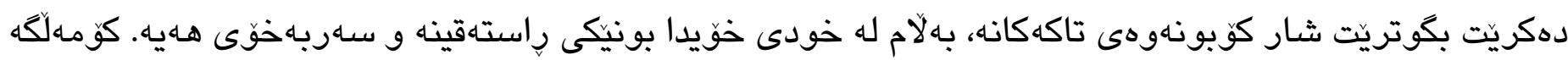

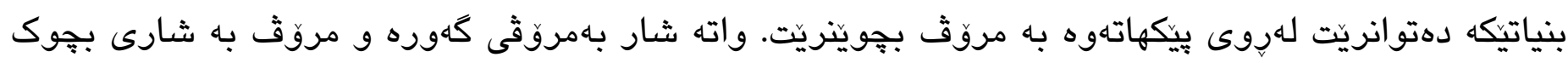

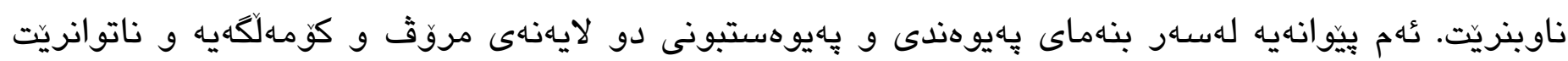

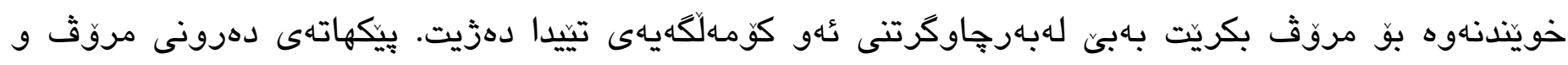

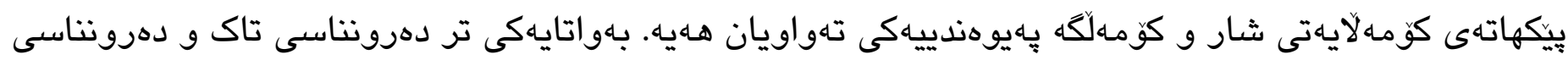

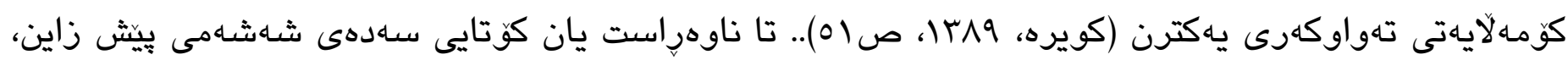




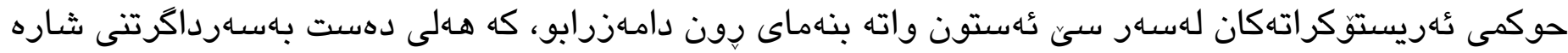

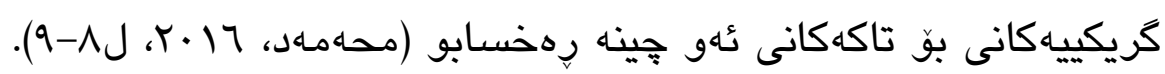

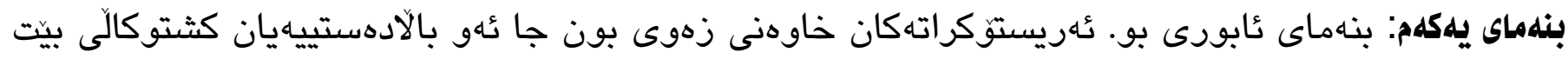

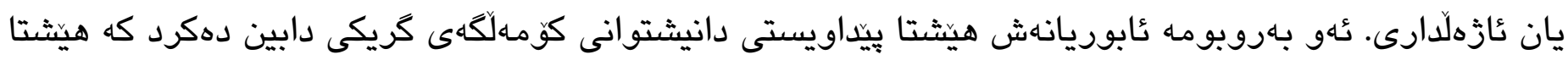
فراوان نهبويو داواكاريهكانيشيان زوّر سادهبون. بهم شيوهيه ئهرستوكراتييهكان بهزالبونيان ئهو تاكه بهروبومه

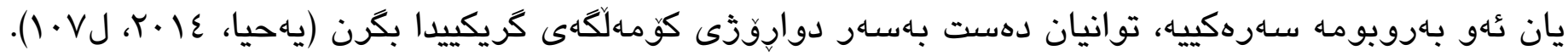
بنهماى دوهم: بريتييه له لايهنى سـاربازى. بارودوخى ولآتى كريك وايكردبو تاكهكانى جينى ئهرستوكراتى دهسهالاتيان بـاهـهر هيزّى سـاربازيدا بشكيت له ولآتدا. شـهر لهنيّان شـاره كريكييهكاندا قهبارهكهى دياريكراو بو. يارسانكى قهبارهى دياريكراوى تُهو بـرزهوهندييه ئابورييه بو، كه ناوجهاهييو و له بناهدتدا له دهورى مال و سامانى ئهرستوكراتييهكان دهسورايهوه لهوهى لهزهوى كثتوكالّى و شوانكارى هـهيانبو. پِاشـان لهو كاتهدا شـهر

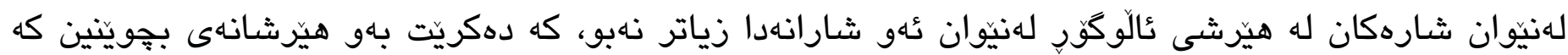

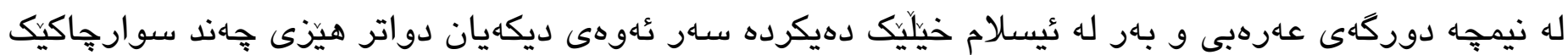
بهسبو بوّ تُوهى بهرهو روىى عُهو هيّرشانه بينهوه (Cary and Haarhoff, 1961, p. 225).

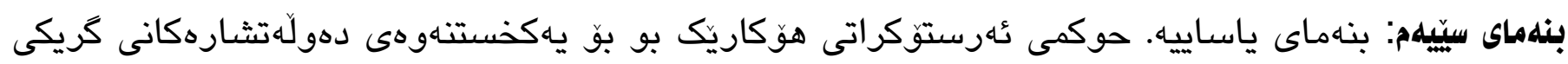

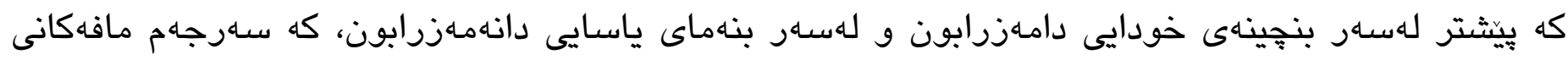

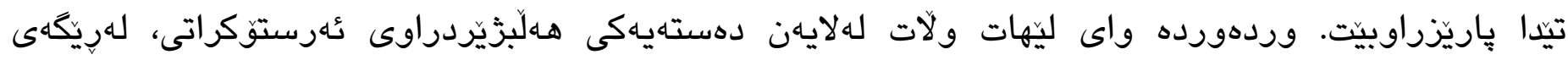

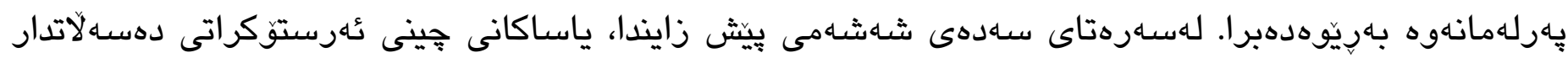

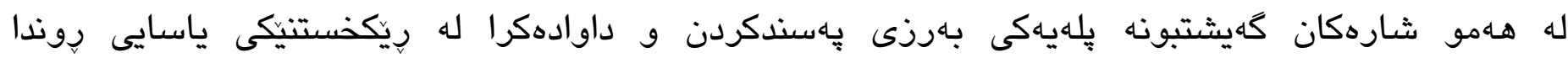

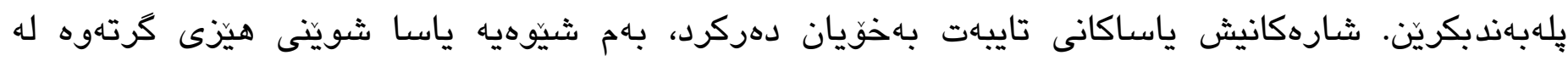
بريارداندا (Finley, 1966, p. 175).

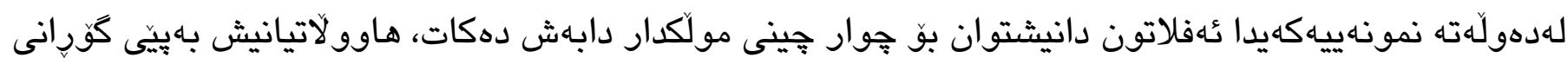

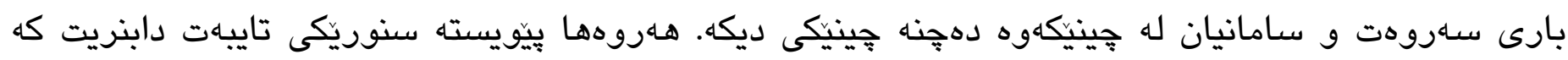

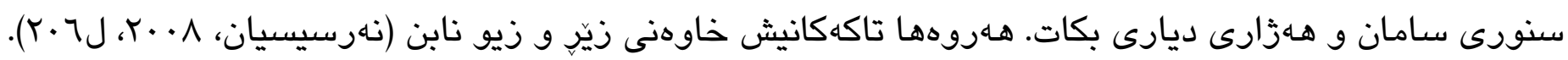

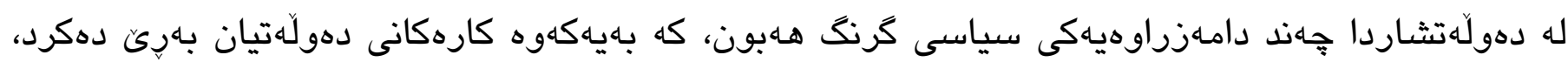
لهوانهاش:

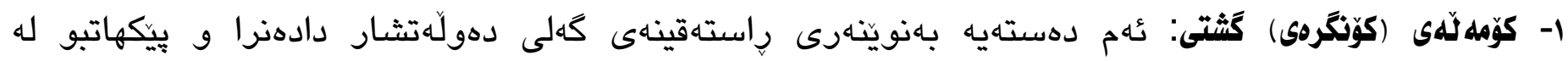
هاوولآتيانى عازادى دهولَهتشار كه تهماهنيان كَيشتبوه بيست سال. بـرزترين دهسهلآتيان هـهبو له شاردا(سالح،

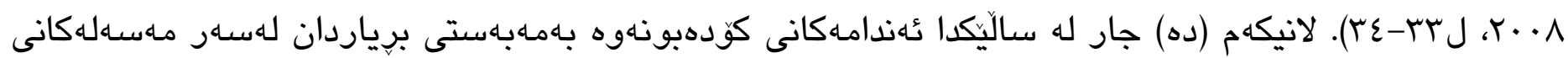

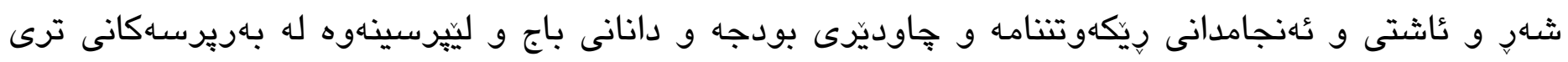

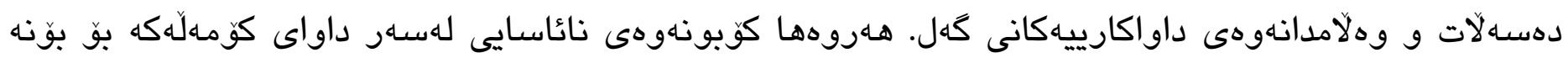




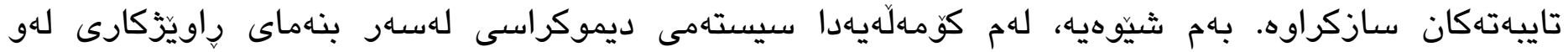

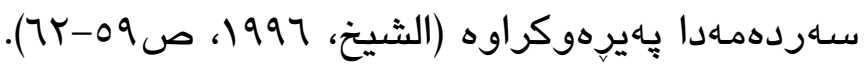

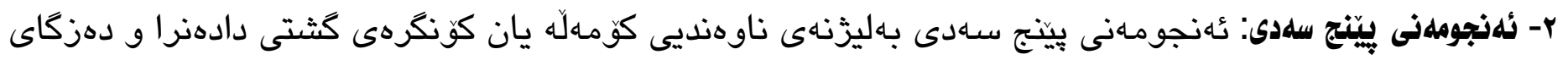

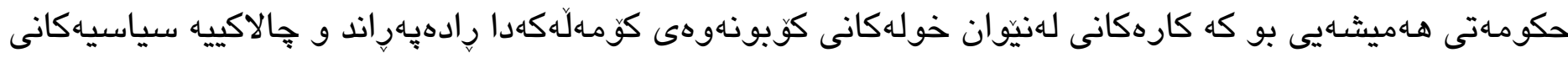

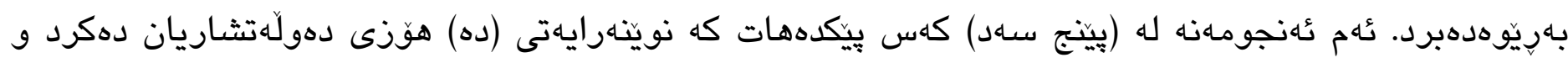

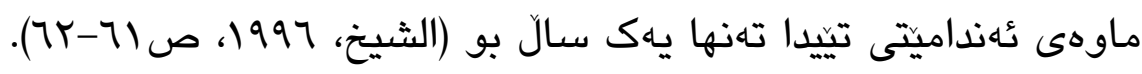

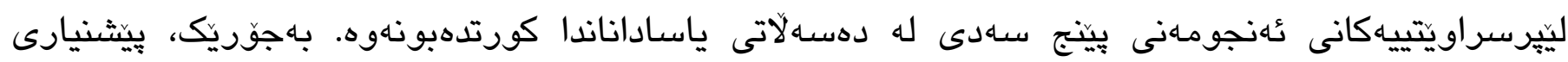

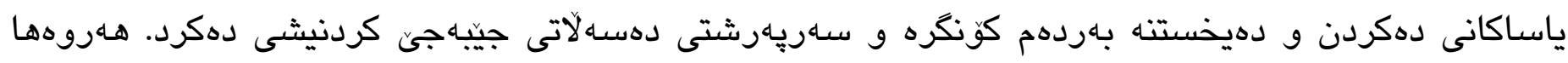

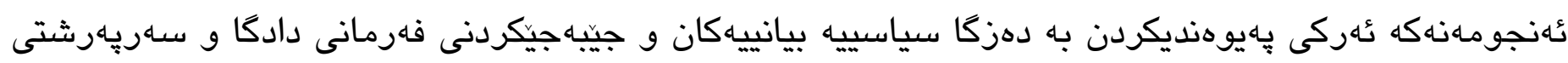

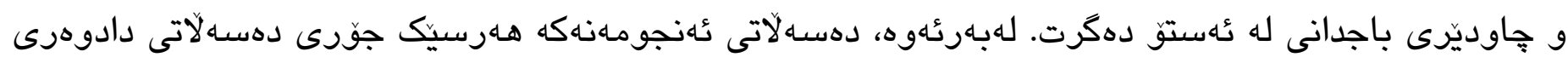

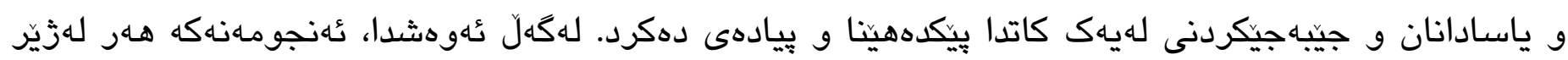

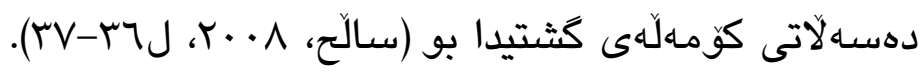

ץ- دادكاكان: دادكاكانى كريك مافى نُهوهيان هـهبوه دهست لهكاروبارى فهرمانبهرانى كاركيِّى وهربدهن و

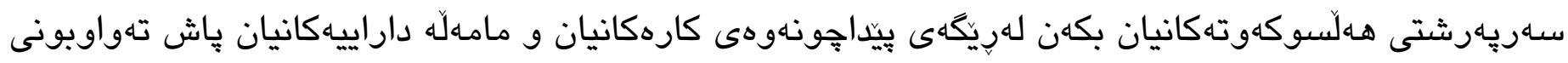
ماوهى خزماهتيان. هـروهها دهيانتوانى هاوكات لهكُلّ دامـزراندنى فهرمانبهراندا برِيار لهسهر ليوهشاوهييان

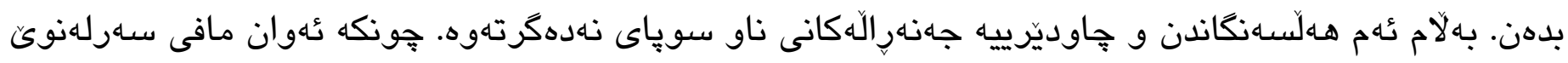

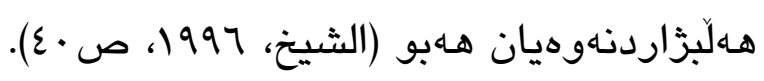

دادكاكان مافى ياسـادانان و كاركردن به ياساكان و راكرتنتيان و هـمواركردنهوهى ياساكانيان هـهبو. ئهماش

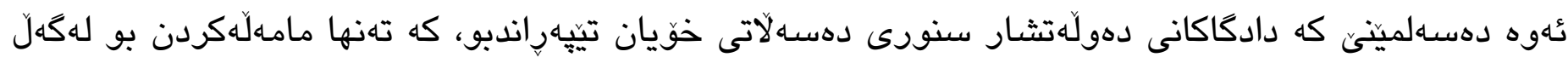

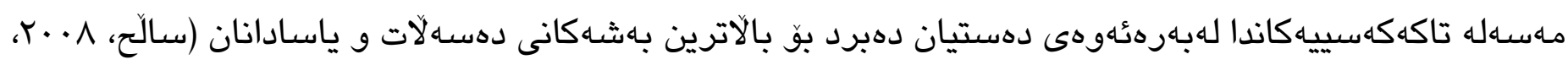

$\cdot(r q-r \Lambda$

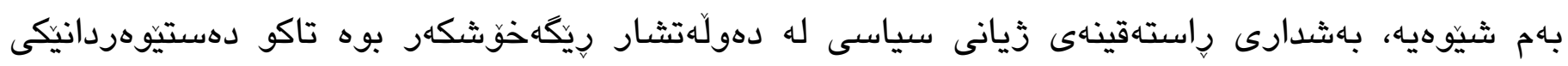

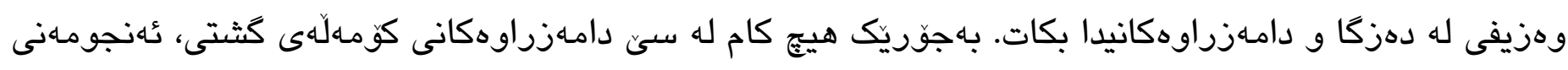

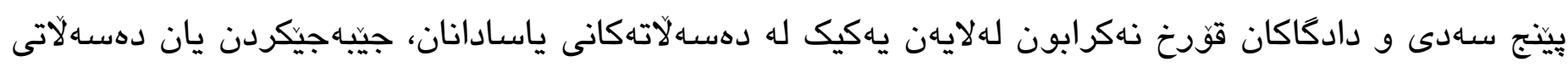
دادوهرييهوه، بهلكو هـهويان بهيهكهوه كاريكُرييان لهسهر يهكتر هـبوه (Pomeroy, 2004, p138).

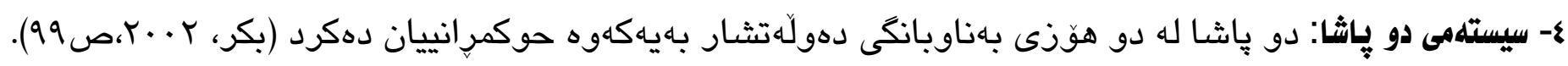
ئهم دو ياشايه هـلّدهتان به سـاءكردايهتيكردنى جهنكهكان و جاوديّرى كارهكانى يهكترييان دهكرد و هـريهكهيان

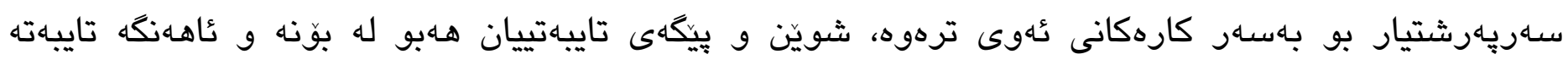

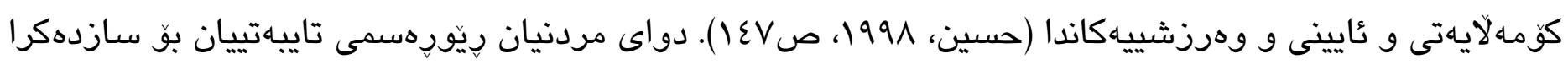

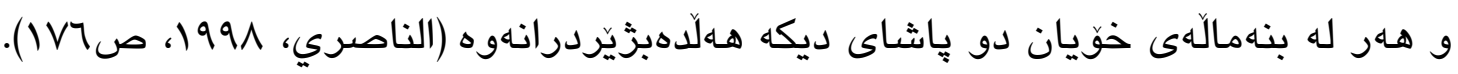




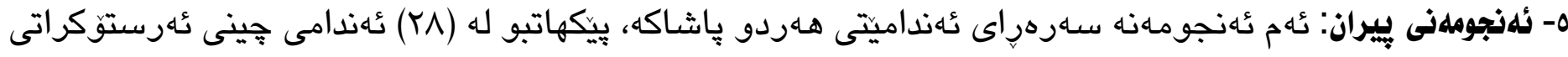

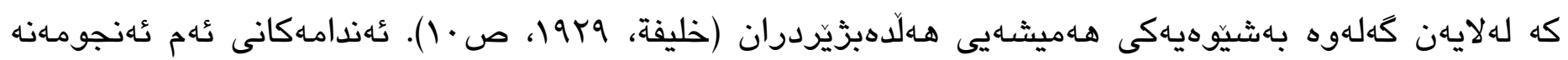

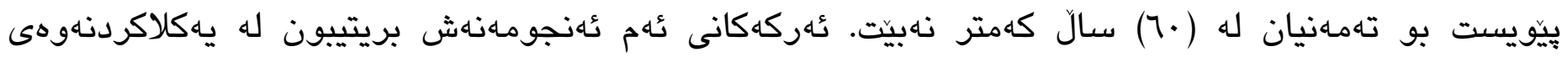

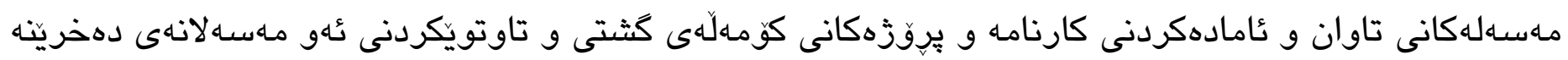

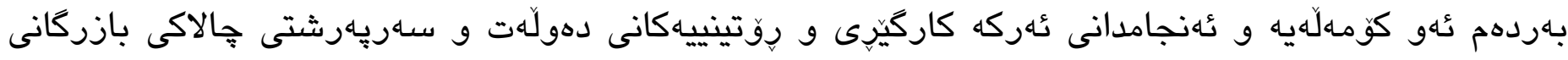

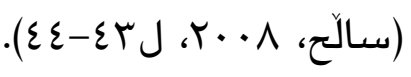

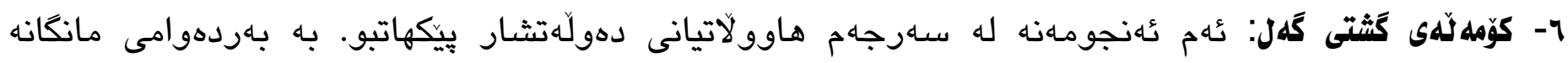

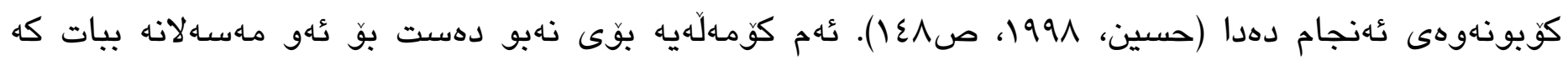

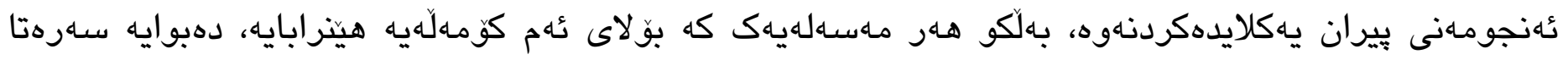

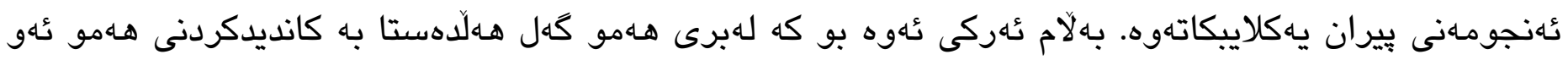

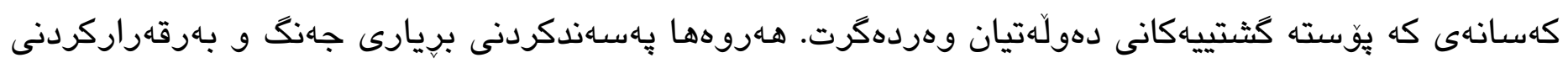

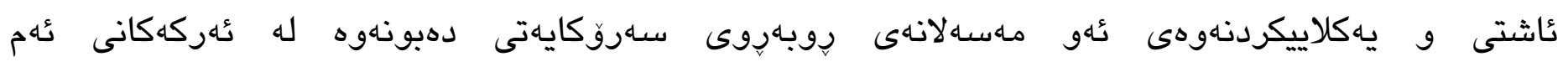

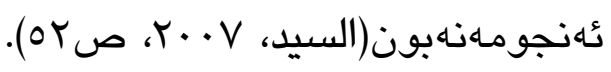

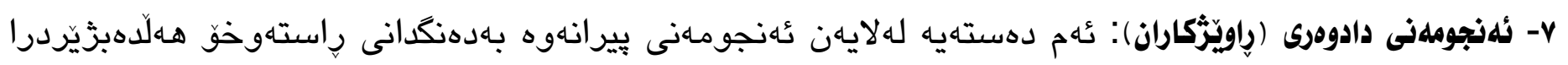

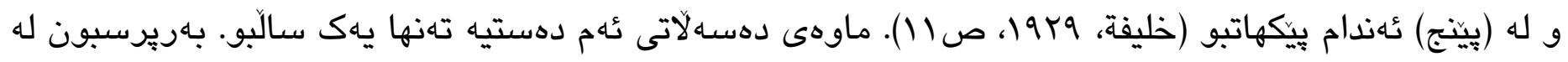

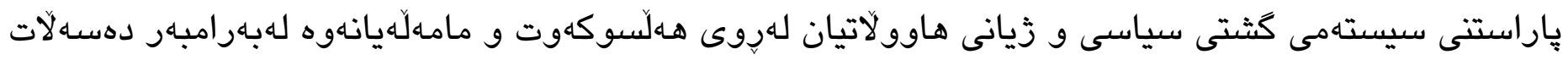

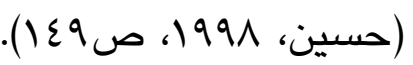

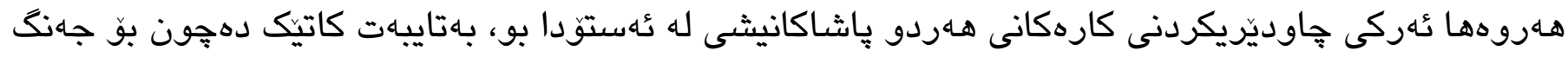

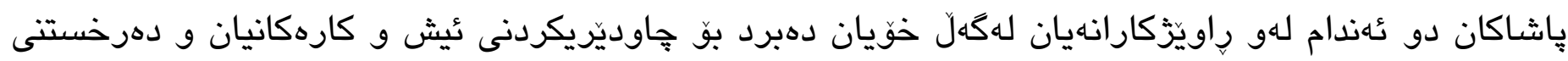

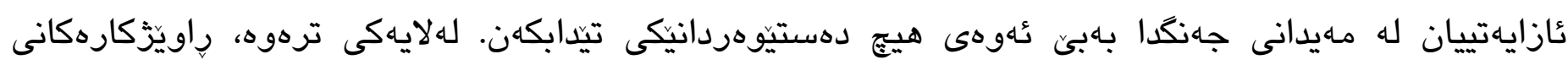

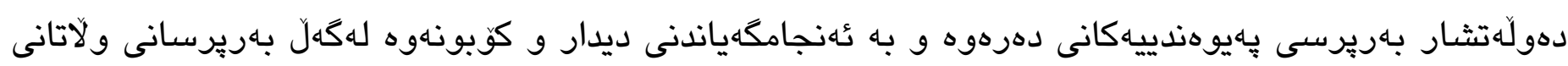

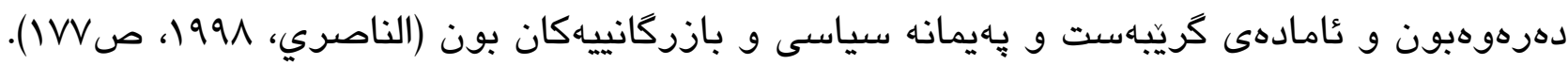

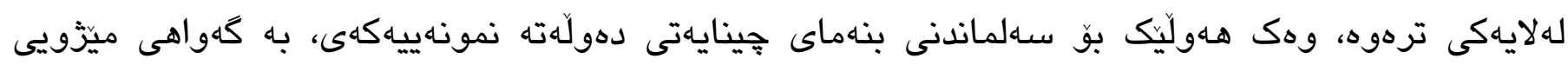

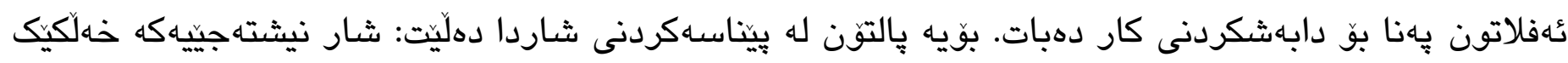

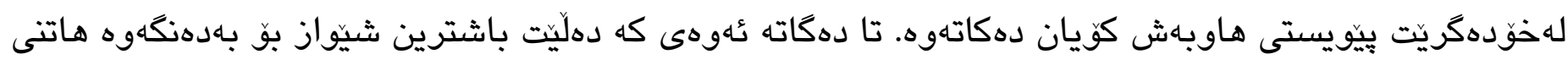

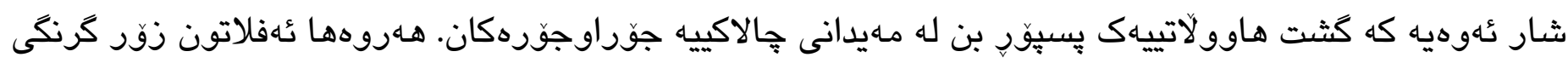

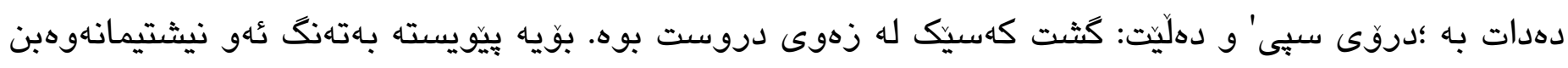

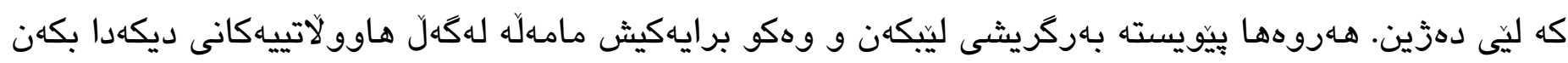

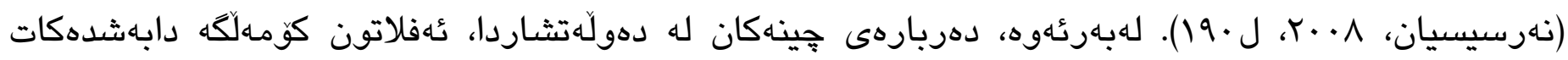

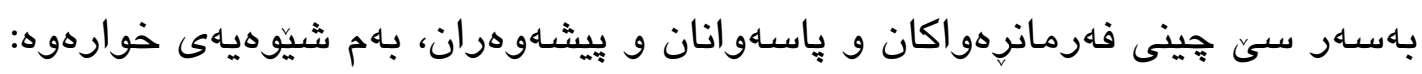


أ- فهرمانرِواكان: يهكهم جِينى شارى نمونهيين، هـروهك له ناوهكهيانهوه دياره، بهرِيّوهبهر و فهرمانرهواى دهولَهتن.

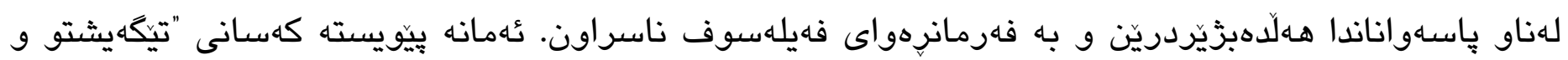

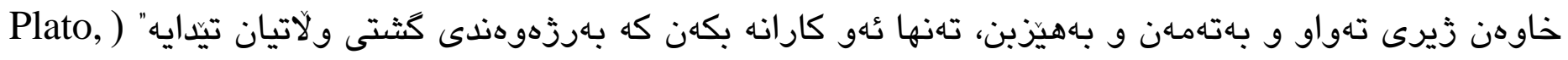
(The Republic, 412b-414b

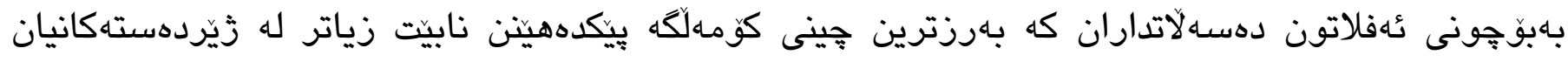

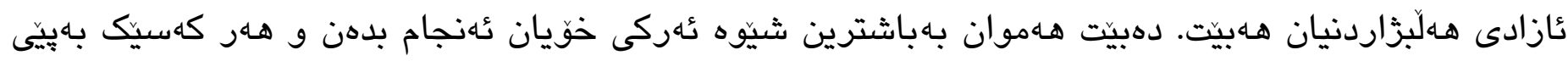

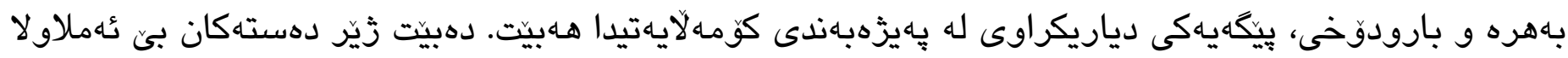

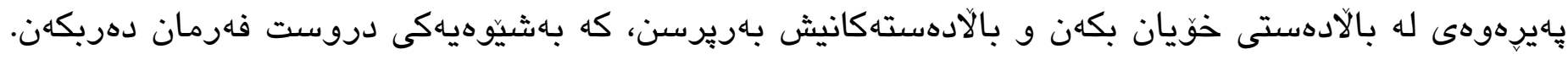

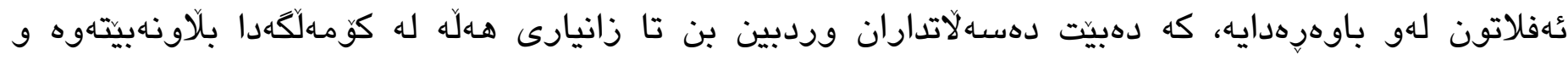

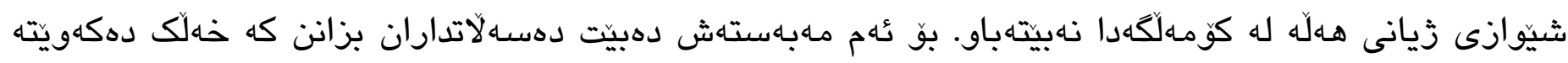

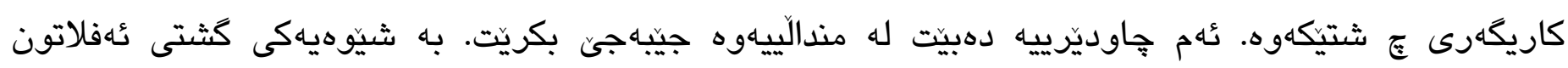

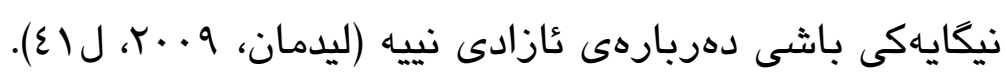

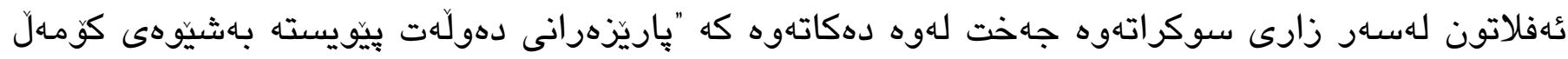

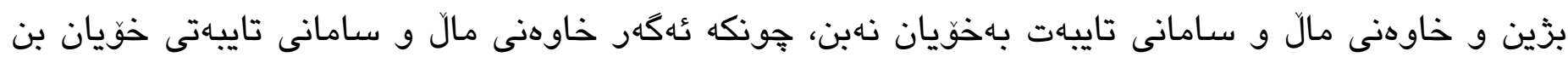

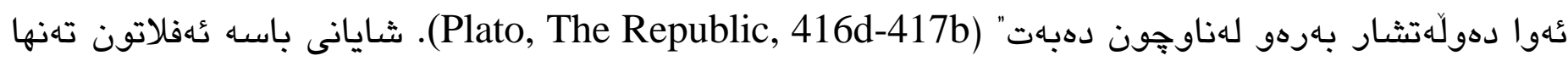

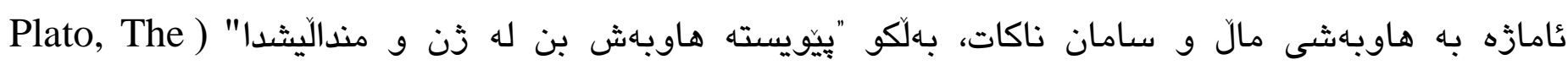
(Republic, 457b-c

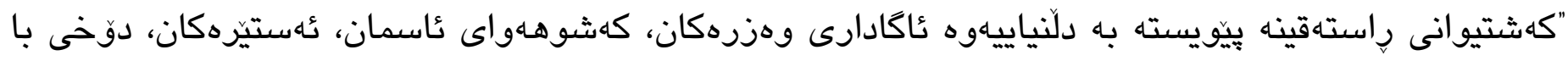
و هـمو شتيكى كونجاو بدات عُكَه بهاراستى بيهويت كهشتيوانى بكات" (Plato, The Republic, 6488d).

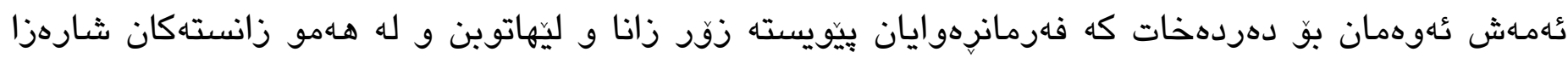
ن.

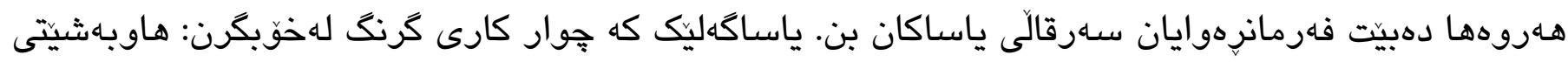

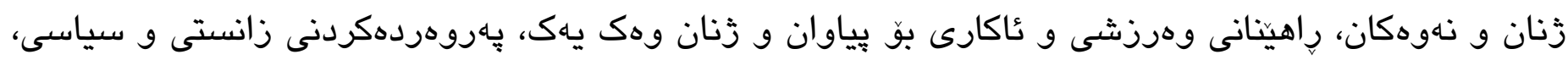

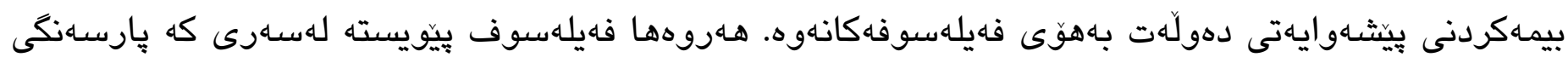

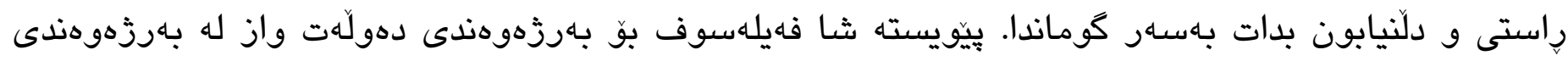

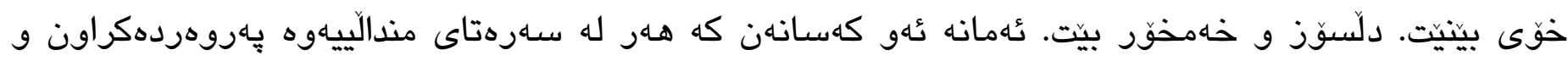

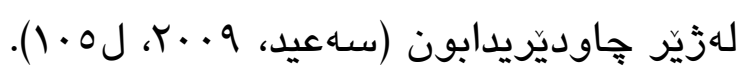

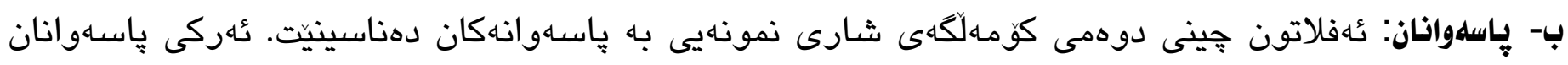

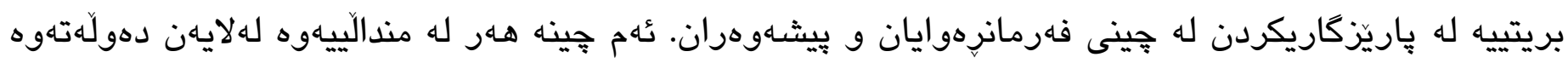

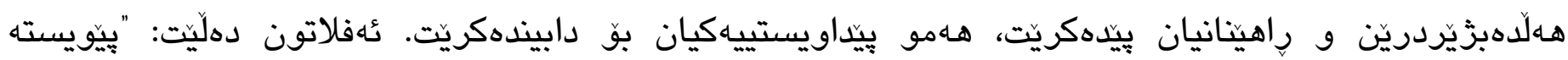




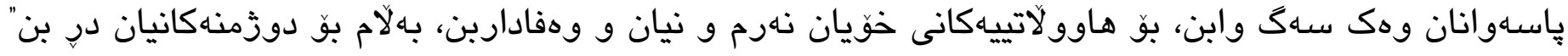

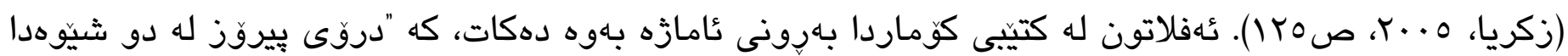

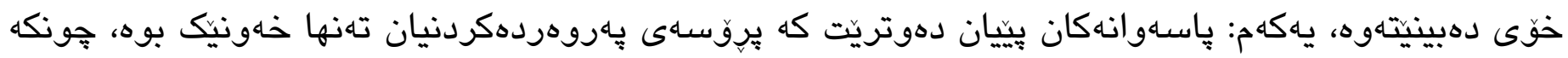

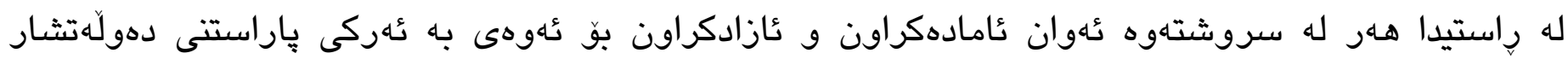

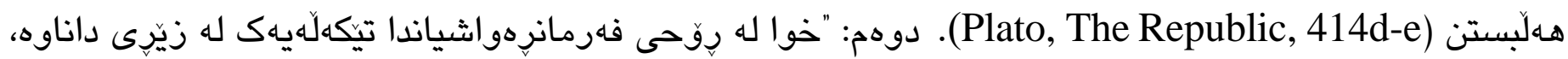

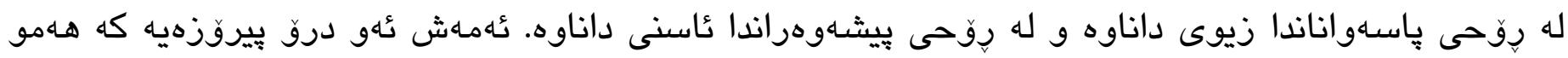
خهلكى دهولّاتثار باوهرى بيّيهيناوه" (Plato, The Republic, 415a-c).

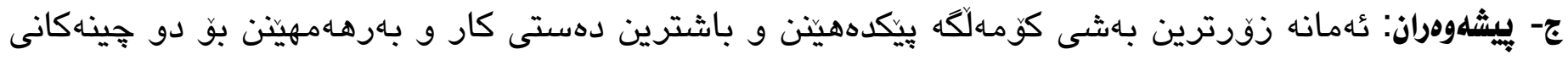

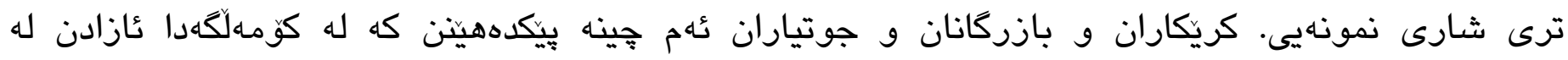
وهجهذخستنهو و خواردن و خواردنهوه و لهبهديهينانى حهز و ويست و ئارهزوهكانيان هيج سنوريكيان نييه.

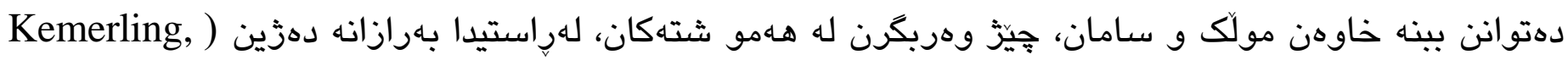

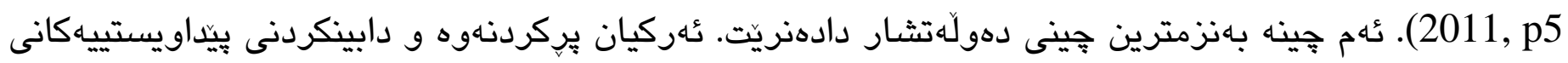

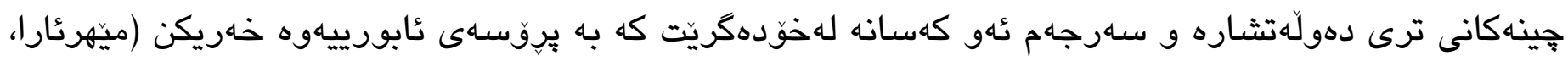

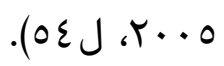

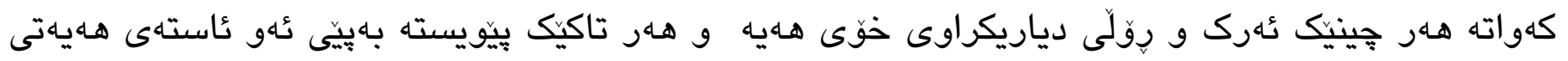

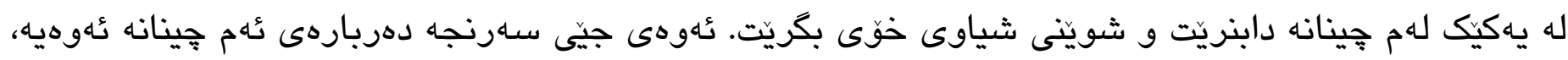

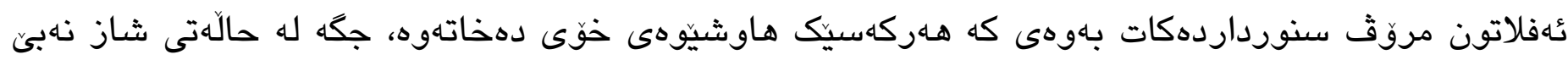
(Burnyeat, 1997, p250)

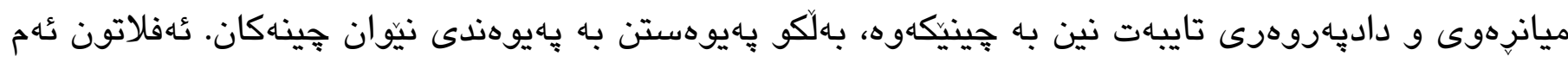

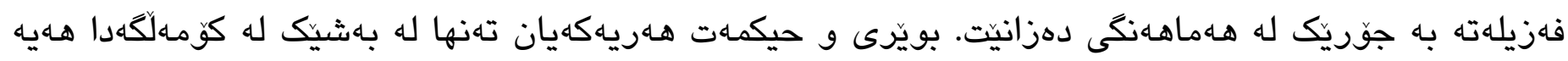

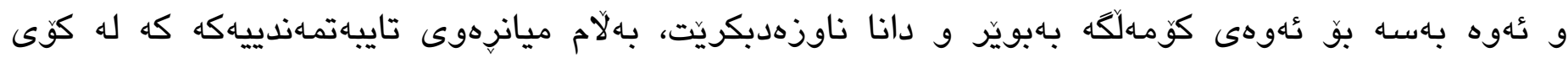

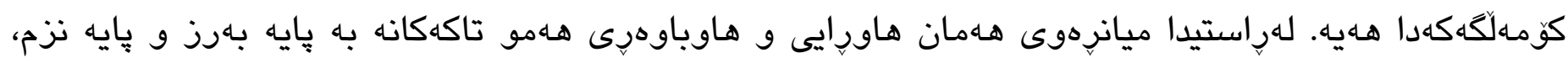

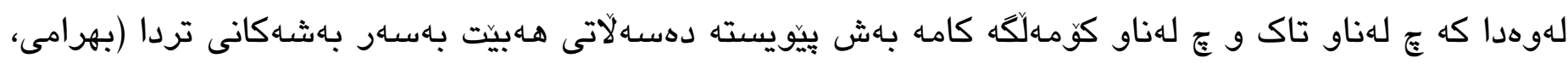

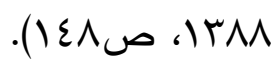

\section{باسى دوهم: سيستهمى سياسى و جوَّركانى حكومهت}

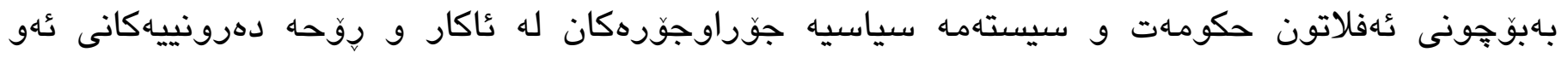

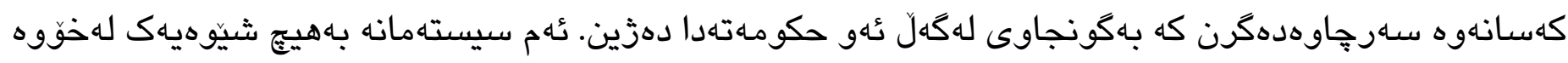

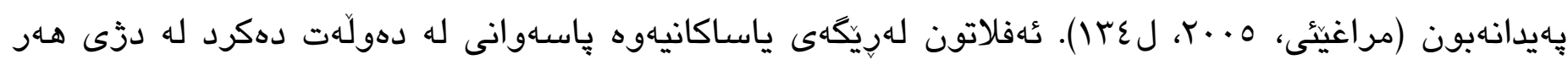

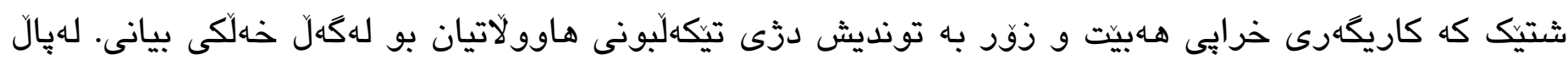




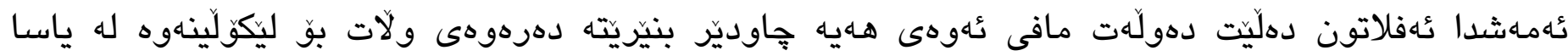

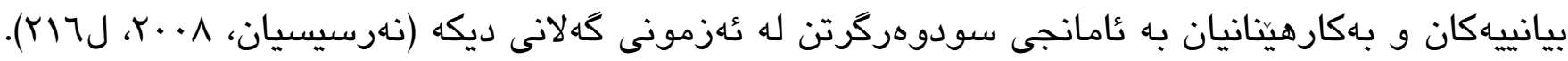

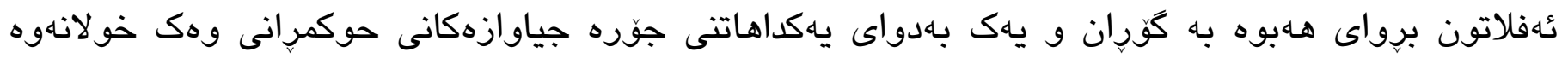

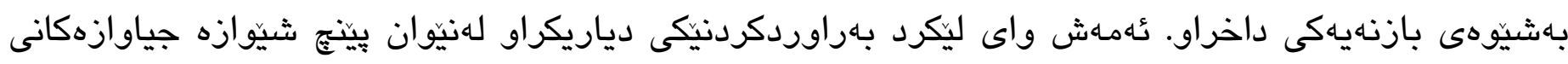

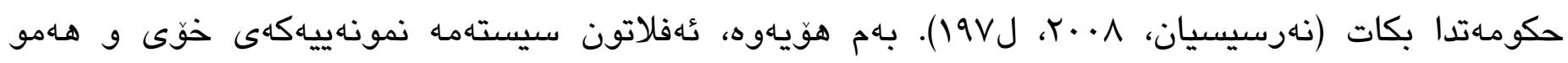
سيستهمه خراب و بهدكارهكان، يان به واتايهى تر، هامو شاره نانمونهييهكان يهك بهدواى يهك بهاييّى ئاستى

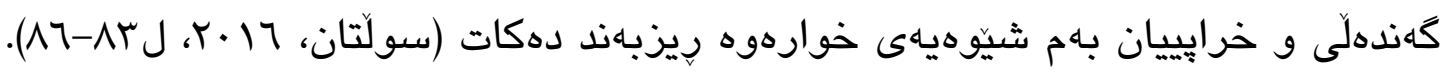

\section{1- ألهربتوكراتى}

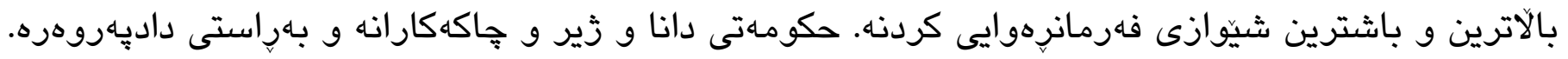

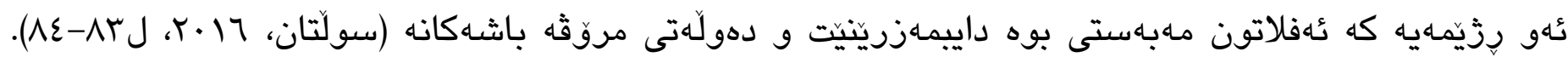

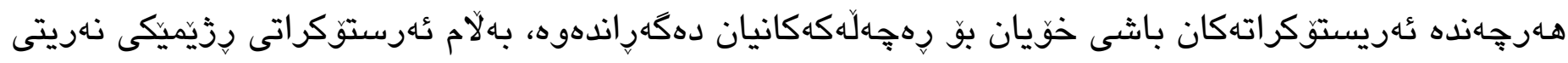

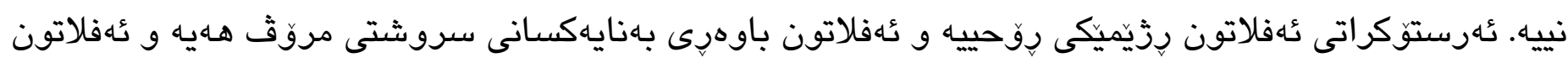

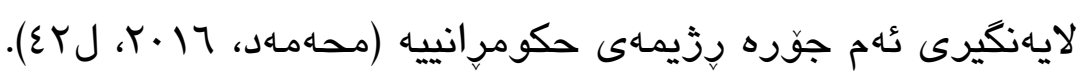

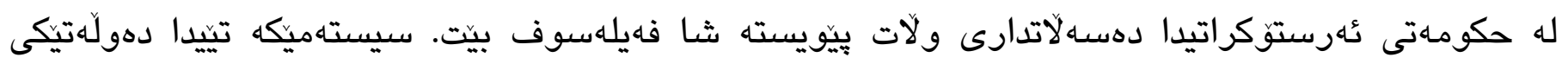

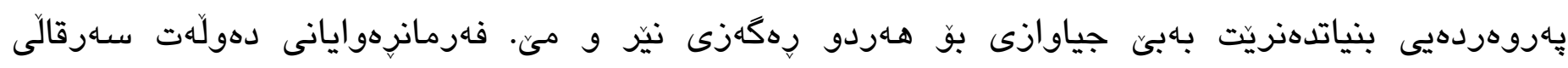

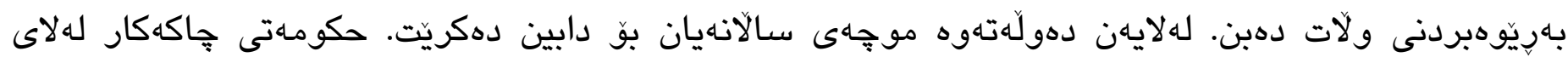

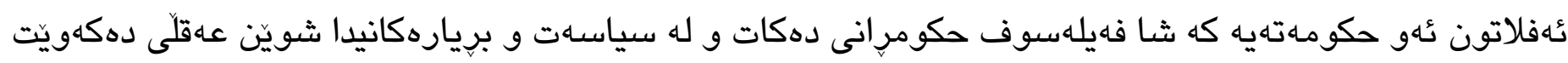

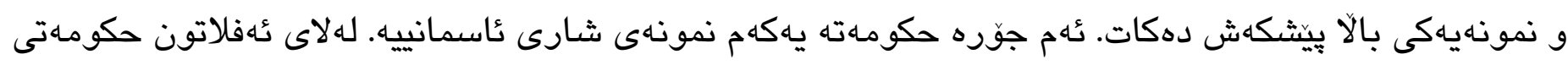

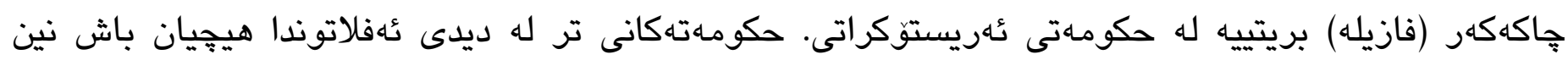

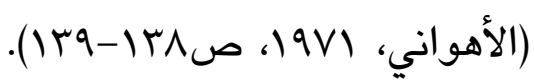

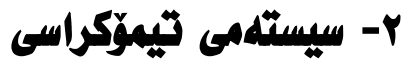

سيستهينكى حكومرانييه كه تييدا شكوماهنى و سهاركهوتنى سهاربازى له هـمو شتيك زياتر بهاداراره. واته لهم شارهدا شكومهندى و بويّرى فهرمانرهوايه لهجياتى دايهروهرى و عاهقل (Plato, The Republic, 547d).

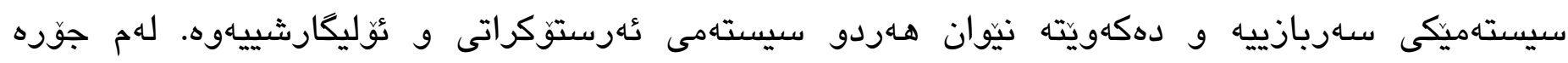

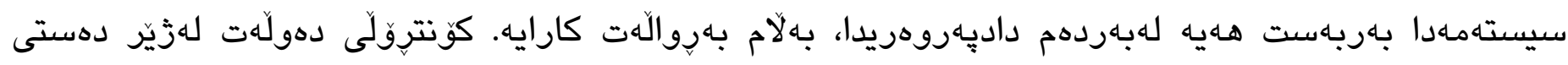

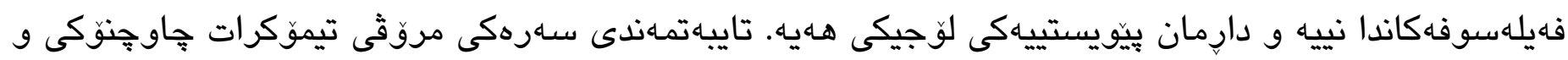

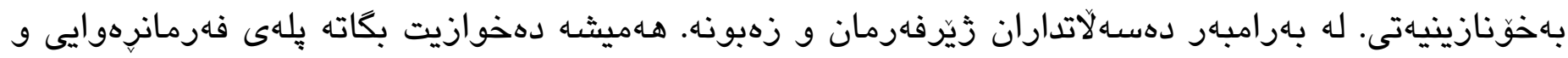

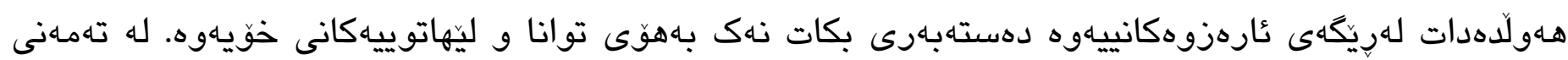


كهنجيدا جاوى زور لهسهر ساهووت و سامان نييه، بهلام تا بهتهمهنتربيت جاوجنوكتر دهبيّت. حهزى له هيزّ و

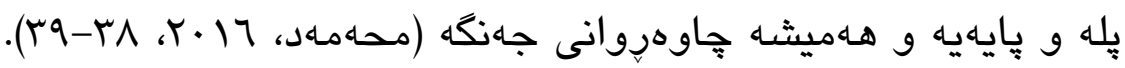

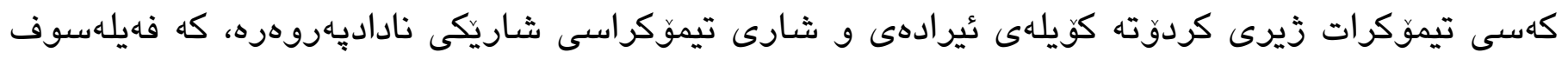

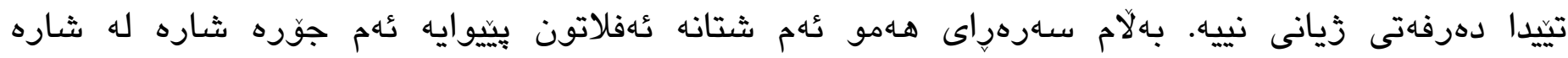

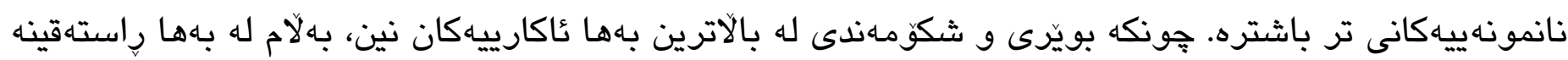

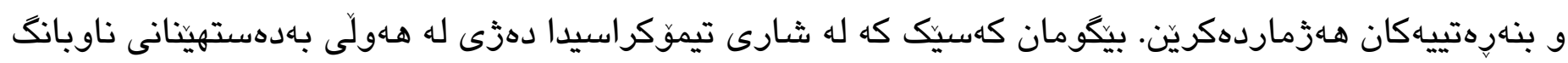

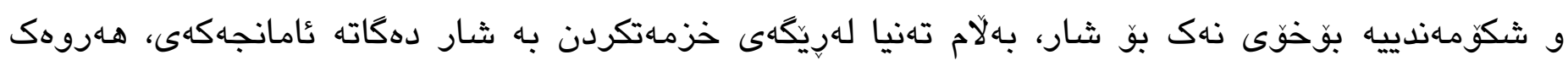

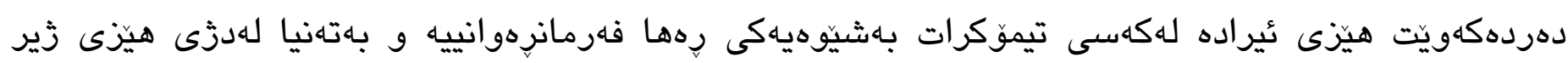

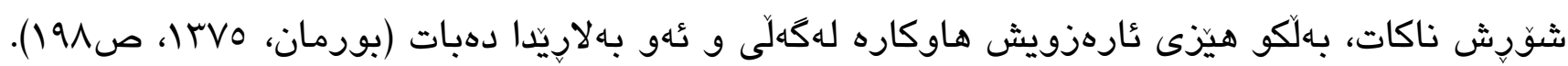

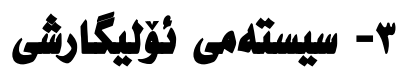

سيستهمى ئوليكارشى سيستهينكى حوكمرانييه، كه تييدا كهمينهيهكى زهنكين جلّهوى دهسهلآتيان له دهستدايه،

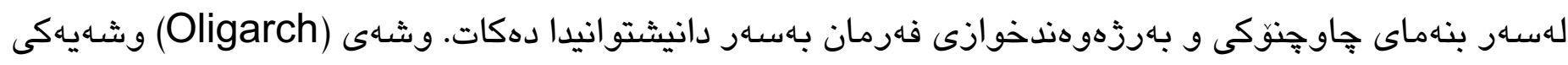

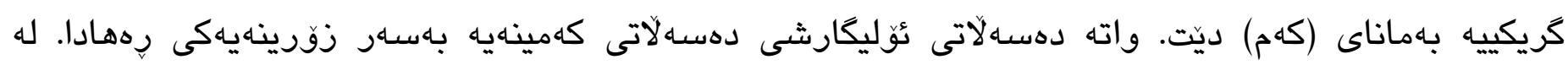

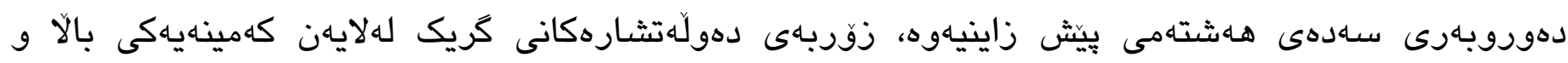

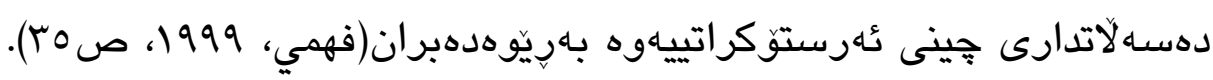

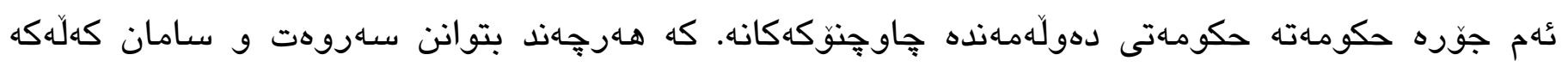

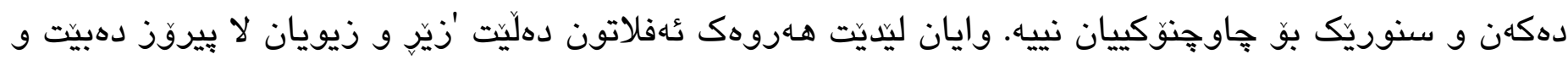

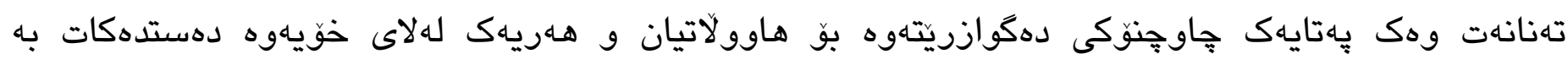

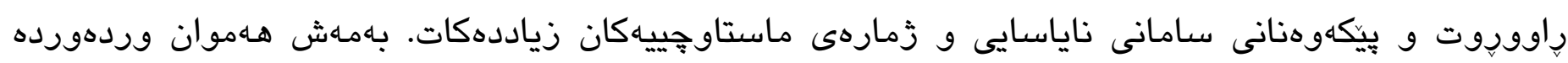

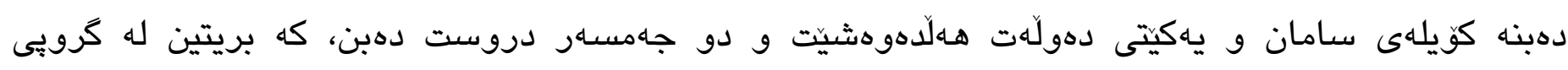

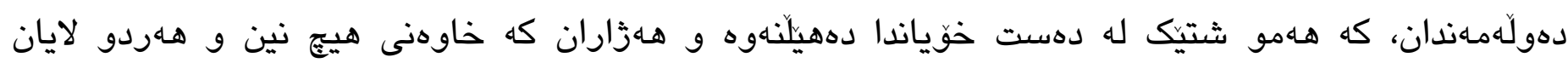

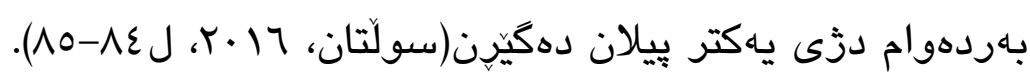

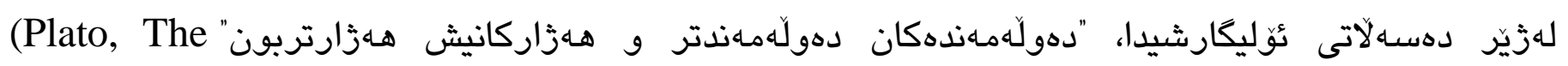
(Republic, 555c-d)

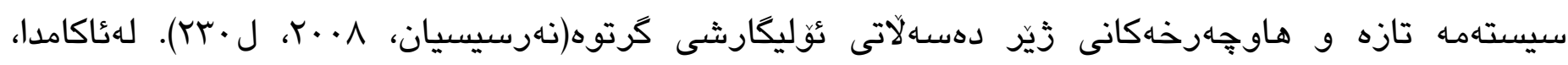

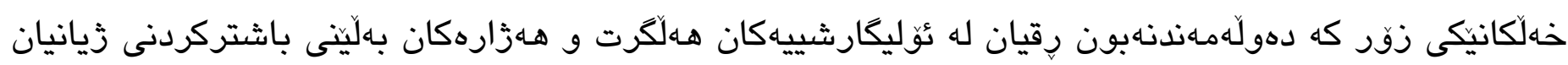

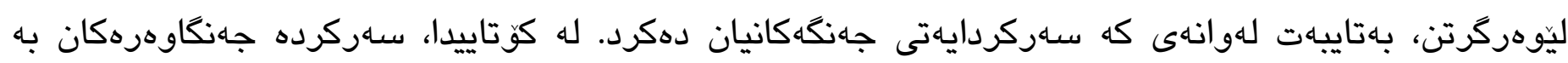

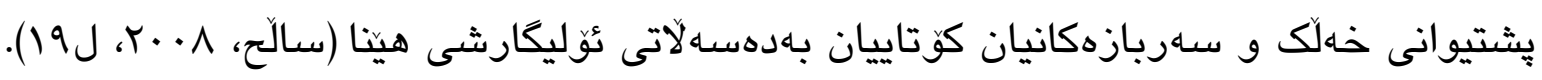


سيستهيكّى حكومرانييه كه تييدا زورينهى خهلكى جلّهويان بهدهتهوهيه، يان ناسراوه به شارى نازادى، واته

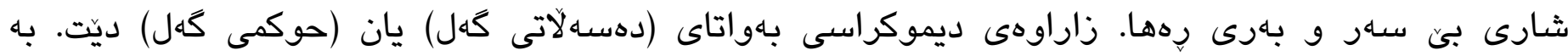

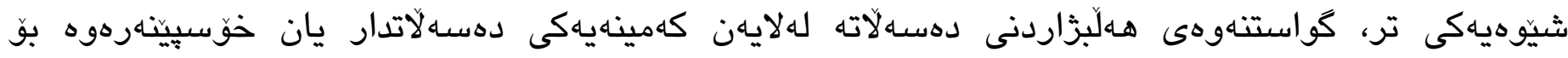

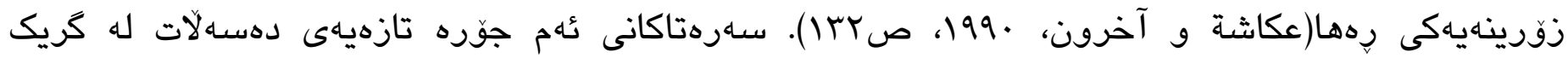

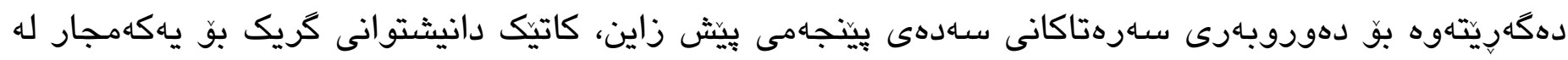

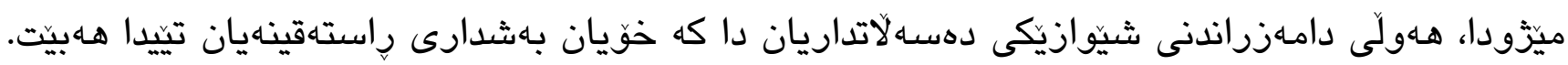

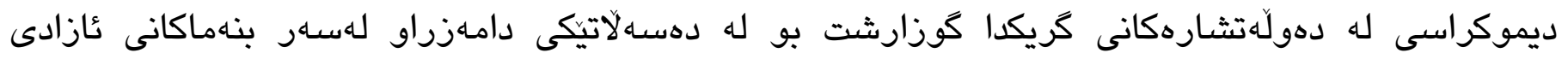

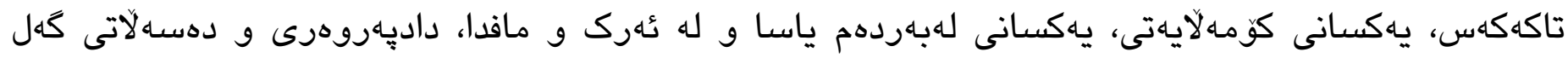

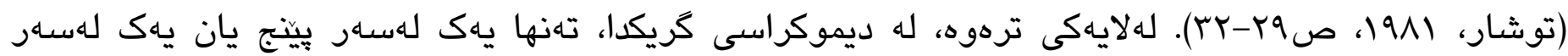

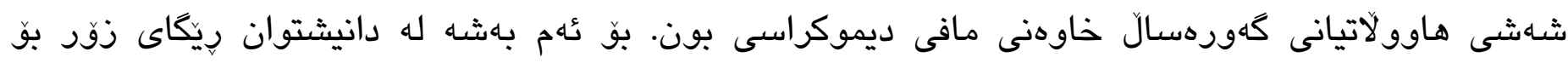

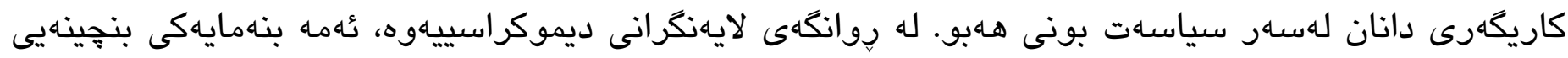

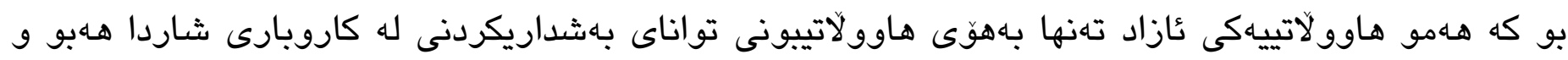

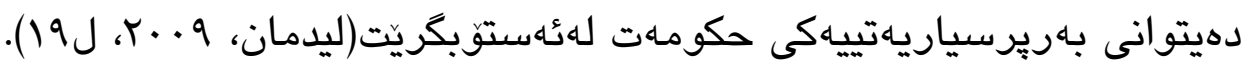

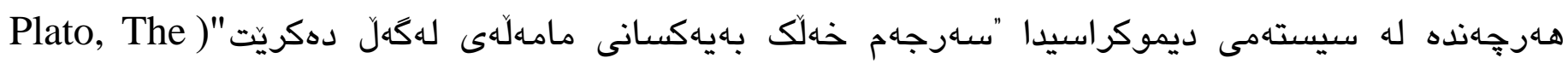
Republic, 558c

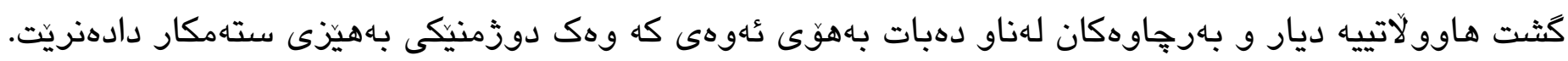

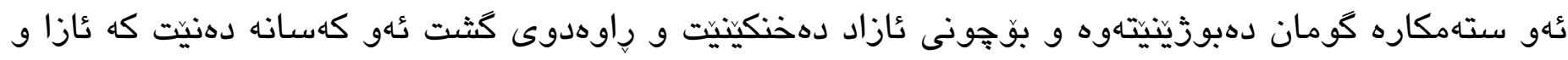

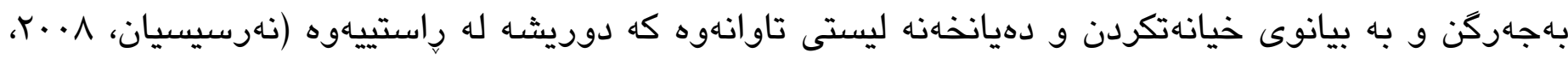

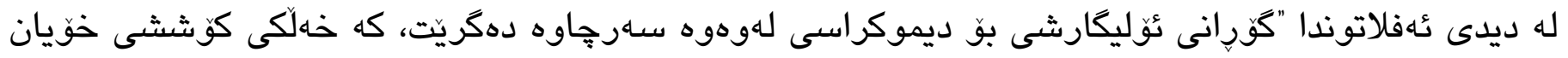

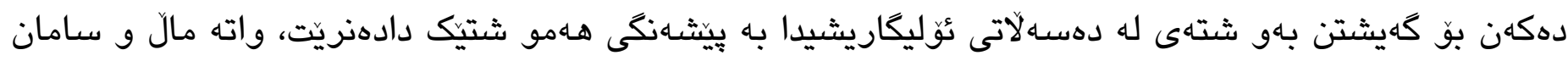

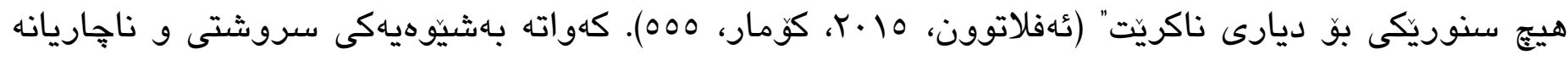

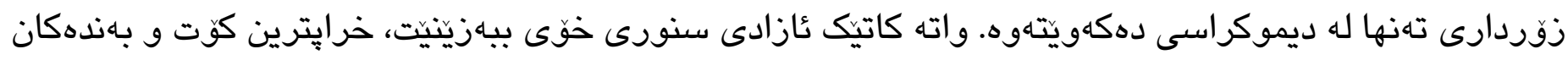

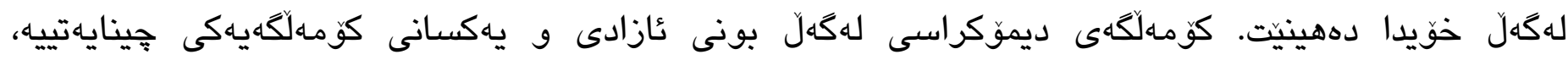

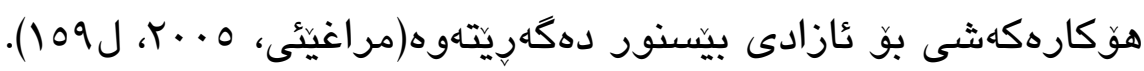

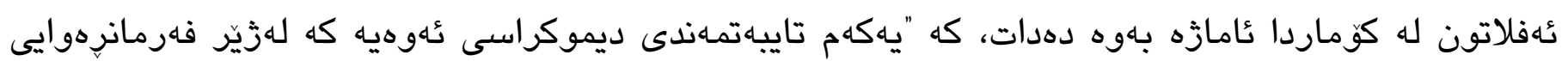

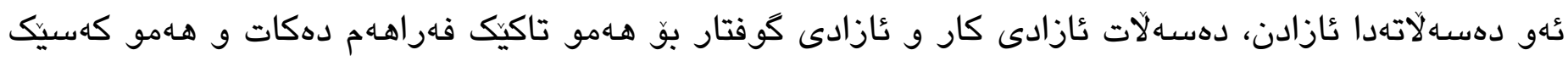

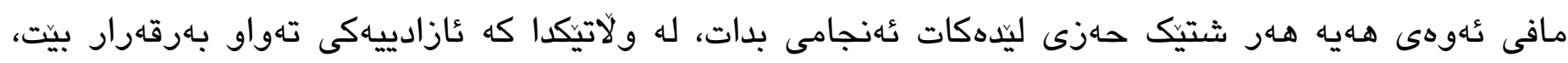

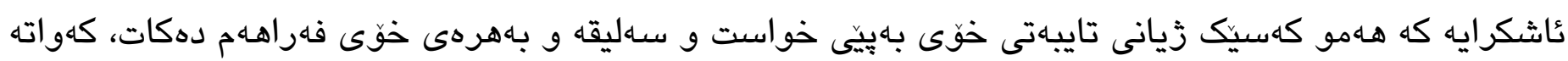




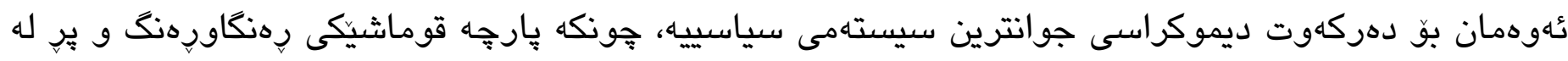

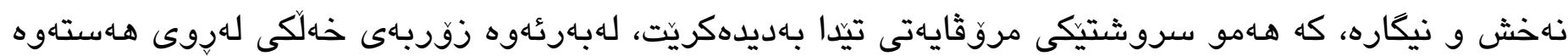

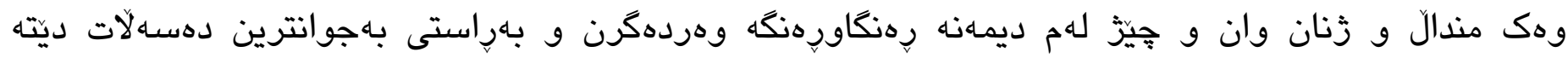

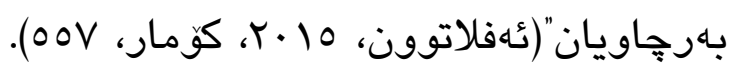

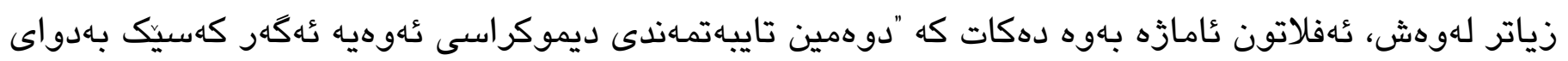

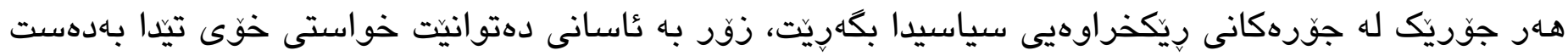

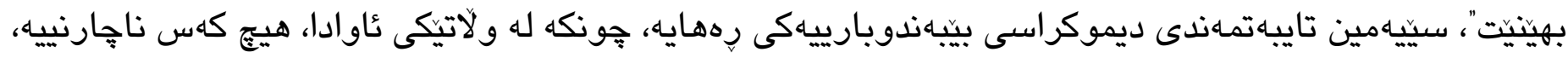

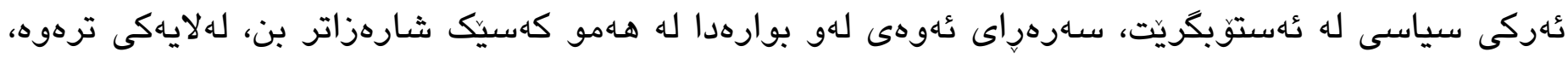

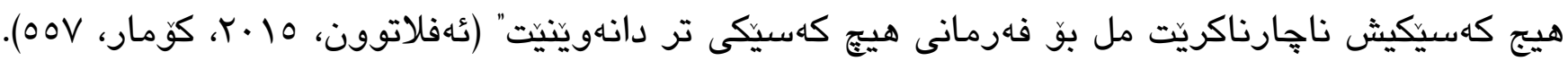

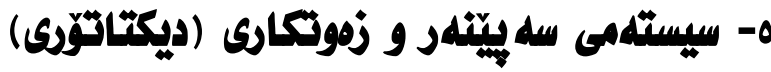

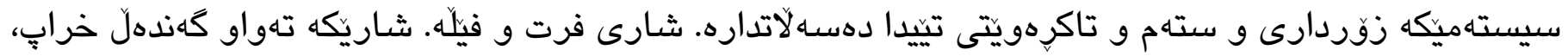
بهاتايهكى تر شارى ترس و تاوانه. سيستهمى زهوتكارى ثامازهيه بو ئهو سيستهمه حوكمرانييهى كه تييدا

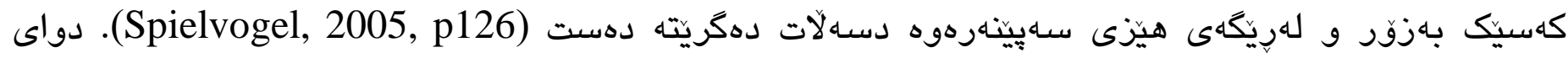

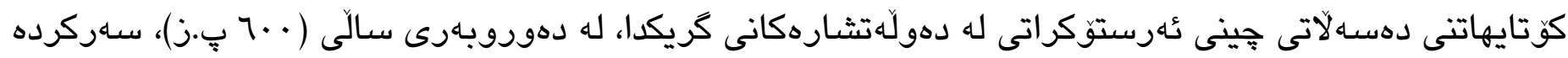

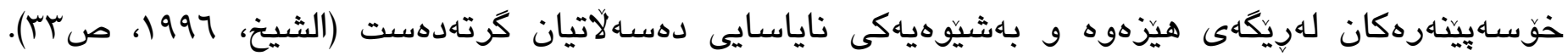

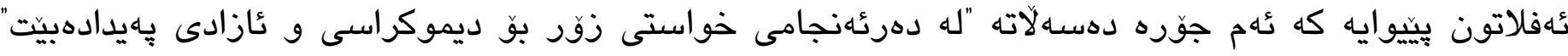
(Plato, The Republic, 562b-c)

دهريجيتيت بـرهو كويلهيى هـنكاودهنيت" (Plato, The Republic, 563e-564a).

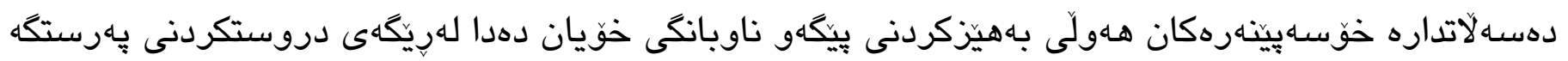

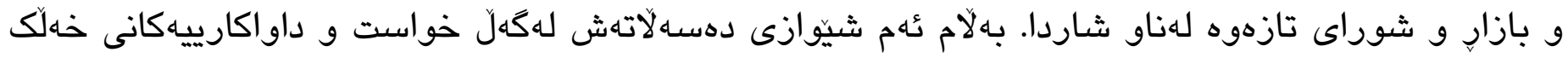

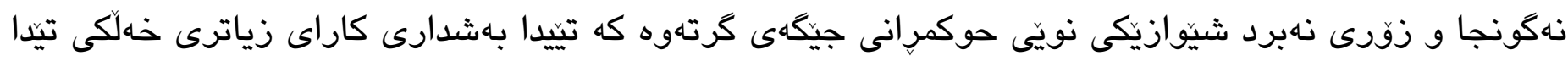

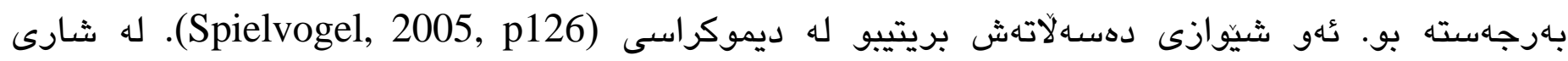

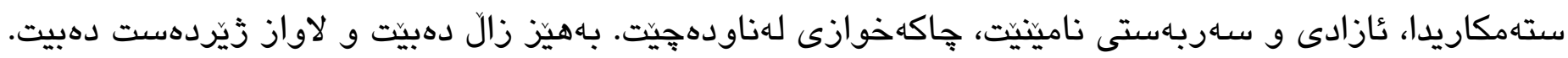

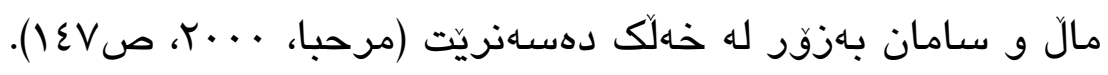

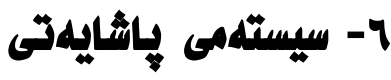

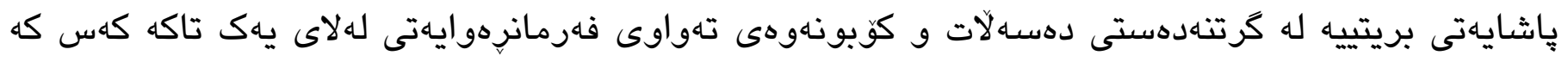

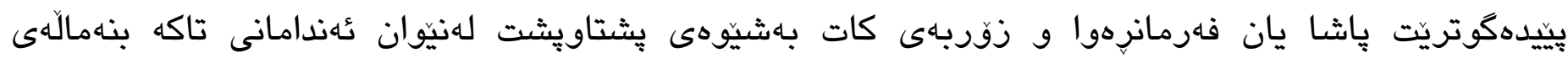

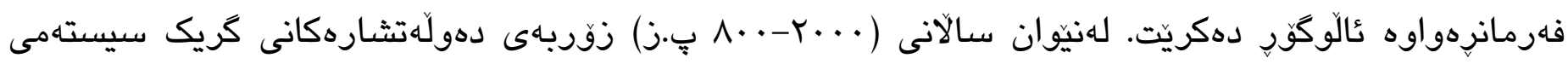




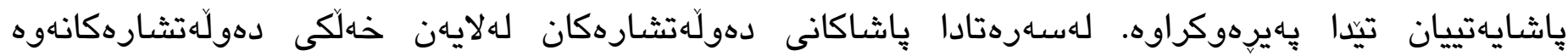

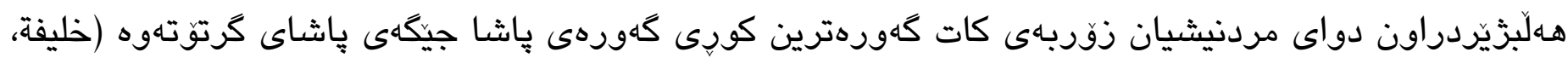
.)( 1949 ياشـاكانى كريك دهسهلآتهانيان جوّراوجوّربو. ياساكانيان دادهنا و وهك دادوهر ئيشيان دهكرد. بوّنه ئاينى و

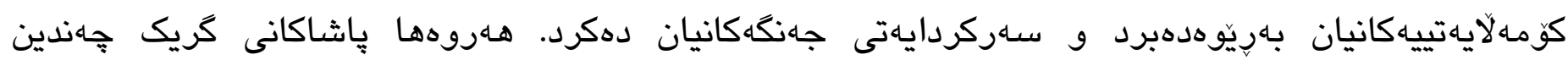

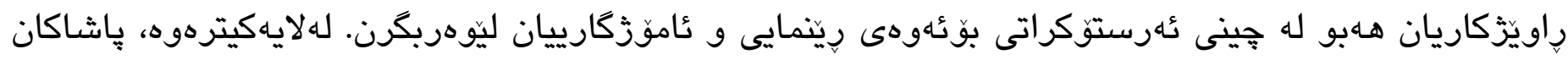

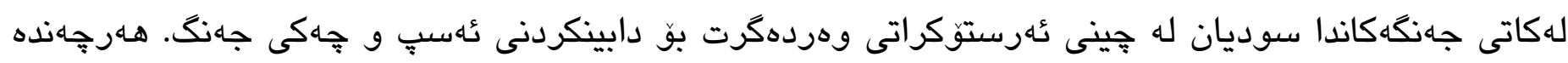

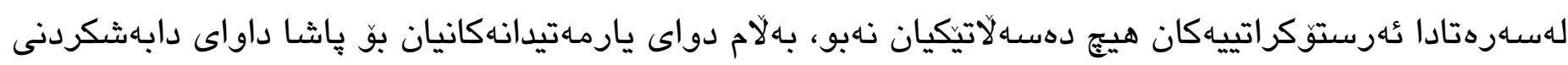

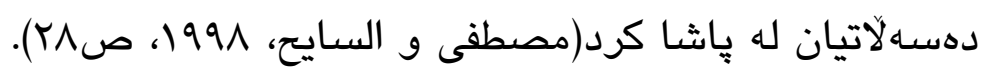

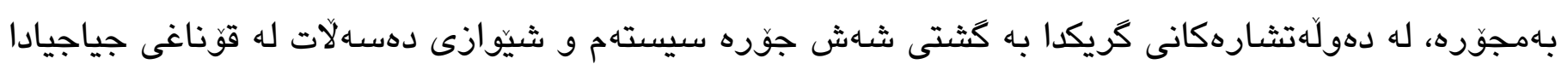

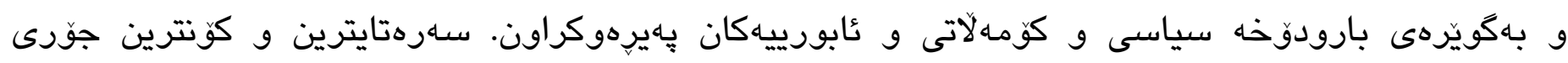

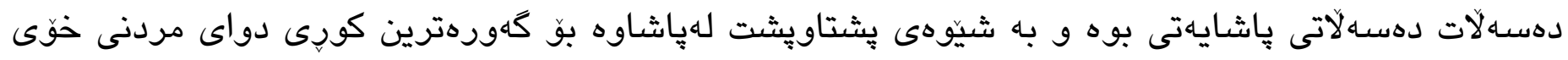

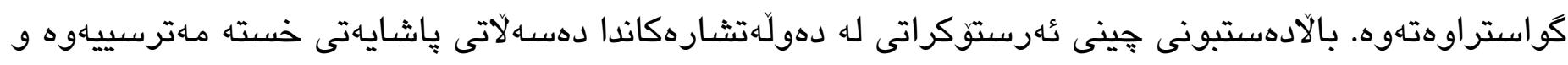

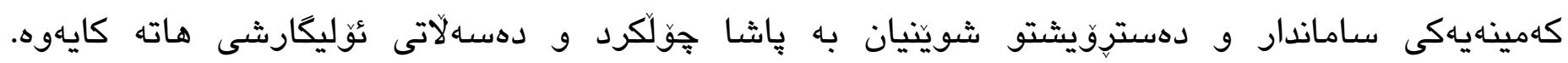

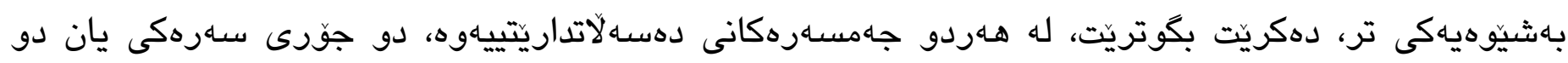

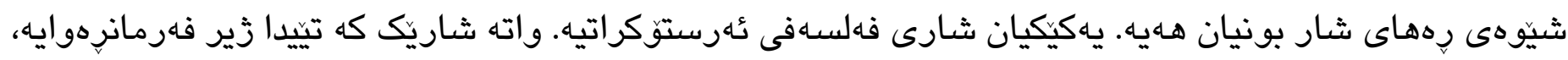

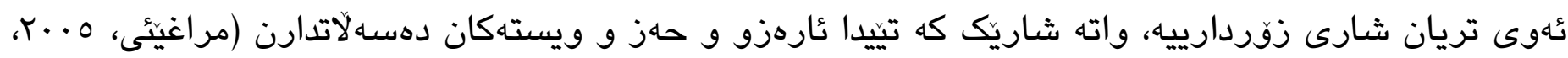

(IrTJ

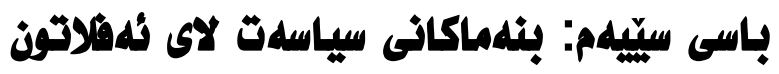

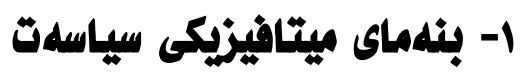

زاراوهى ميتافيزيك له (Meta ta Physika) ى كريكييهوه وهركيراوه كه بهماناى (ئهوديو سروشت) ديتّ. ئهم

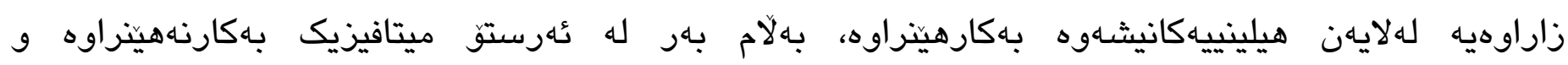

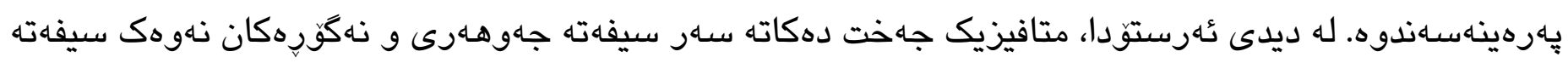

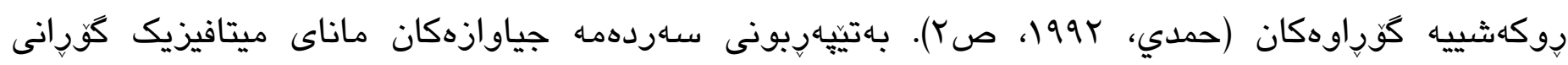

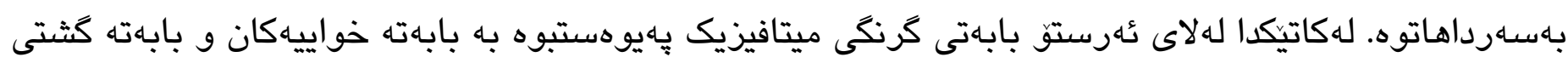
و بنهما نارونهان. بهلاّم له سـردهمى نويّدا له بابهتى بون و بابهتى زانين دهكوليتهوه. له بابهتى بوندا، لهوه

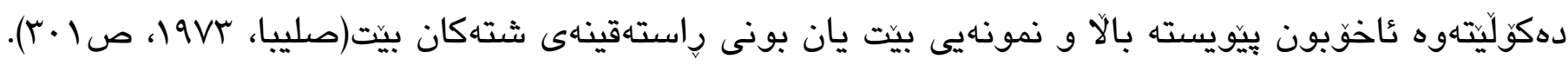
له جيهانى ميتافيزيكى ئهذلاتوندا، راستيتى جيهانى مادى رهتدهكريتّهوه و ئهم جيهانهى ئيستامان وهك تهنها لهبهركيراوهى جيهانى نهمر و راستهقينه وينّادهكيَت. بهم شيّوهيه عُهلاتون جهخت لهوه دهكاتهوه كه بهلايهنى 
كهماهوه دو جيهان بونى هـيه: جيهانى راستاهينه و جيهانى مادى. جيهانى مادى و ناراستهقينه ثئو جيهانهيه كه

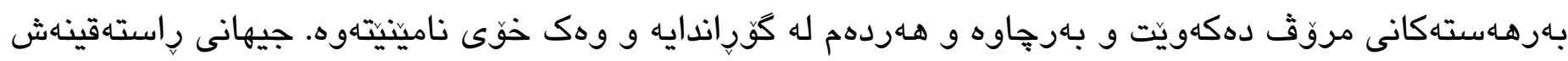

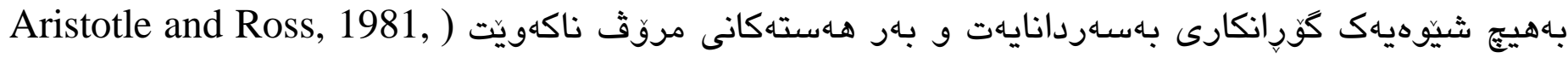
p152). به واتايهكى تر جيهانى ميتافيزيك تهواو جياوازه له جيهانى هـهتهكان. بهجوّريك ميتافيزيك جيهانيكى

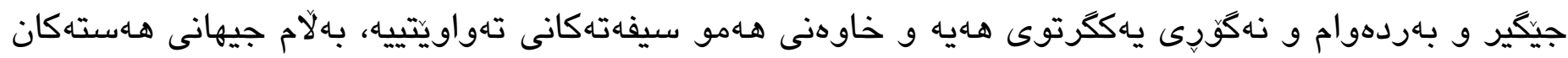
له كَّرانى بـردهوامدايه و رويهكى ناراست و لاسـايى كردنهوهى جيهانى ميتافيزيكه. عهقلى سروشتى ناتوانيت

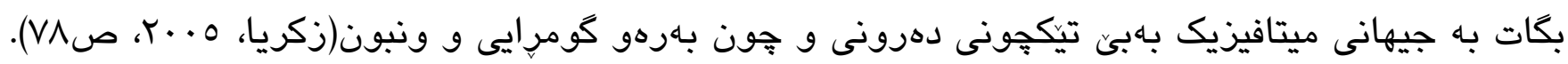
له ديدى ئهلاتوندا جيهانى راستاقينه بريتييه له جيهانى ديدى بالاّ يان جيهانى كَانى نهمر. ثُهلاتون يِيى وايه

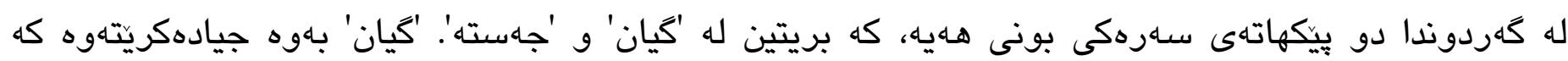

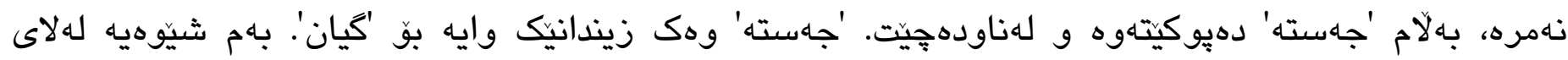

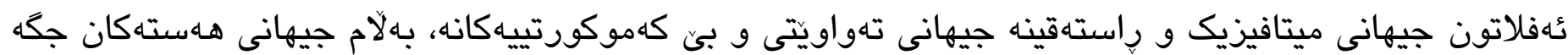

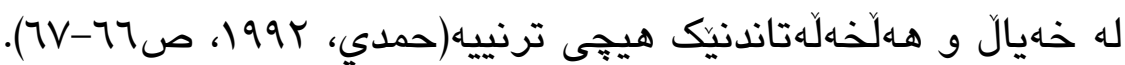

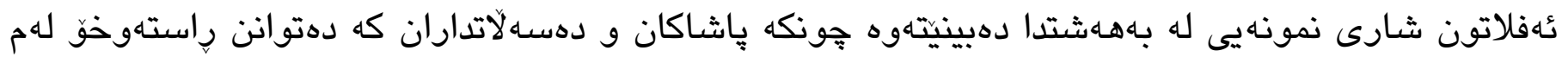

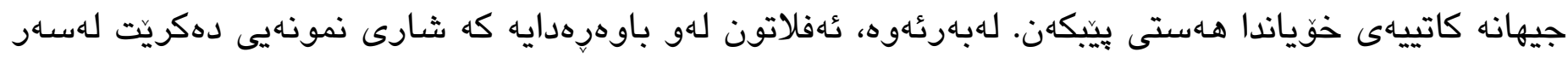
زهوى و لهم جيهانه كاتيهدا بهادى بهينتريّت للهلايهن شافهيلهسوفانهوه. ئهمه ئهوه دهكَهيهنيت كه شارى نمونهيى

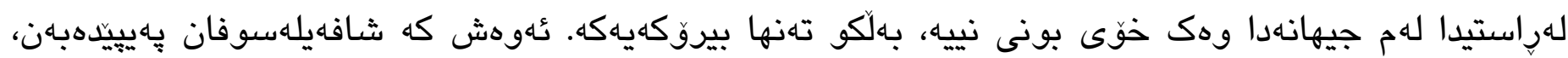

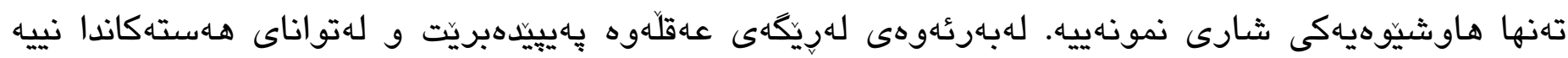

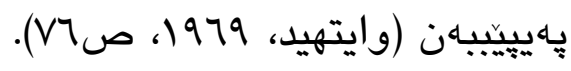

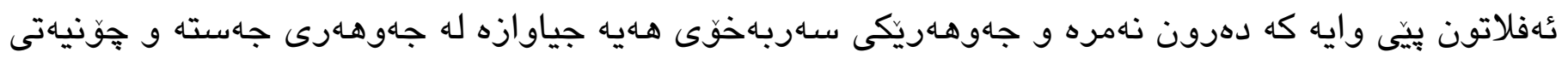

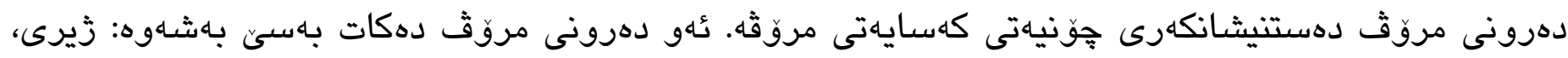
ئيراده و ئارهزو. ذيرى هاوتايه لهكَلْ رِّلّى فهرمانِرهواكان له شارى نمونهيدا و دهتوانيت وهك فهرمانرهواكان

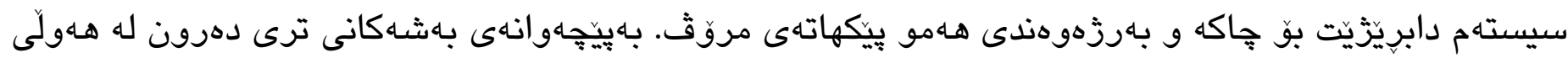
بهاديهينانى بـرزهوهندييهكانى خُوى نييه و تواناى تئوهى هـيه بوّ كهيشتن بهباشترين و بالآترين بهرزهوهندى و

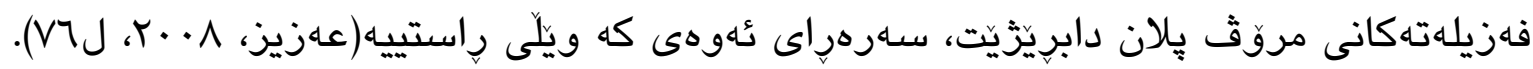

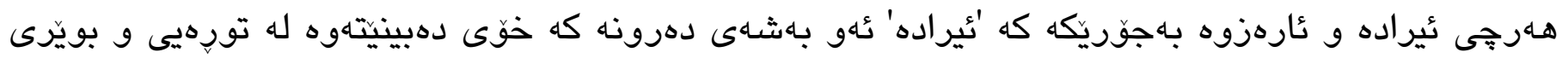

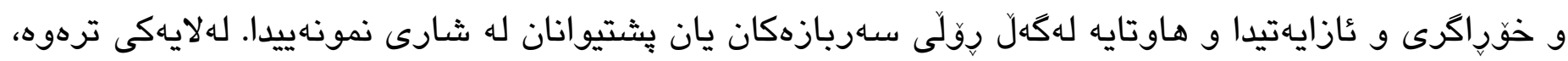

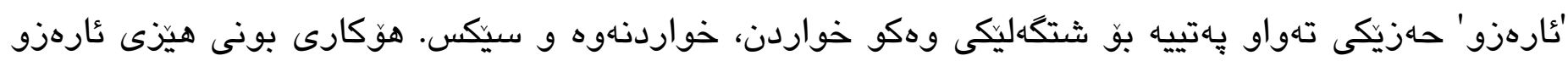

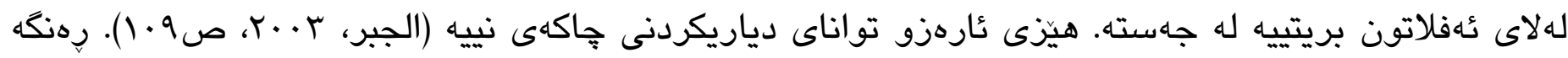

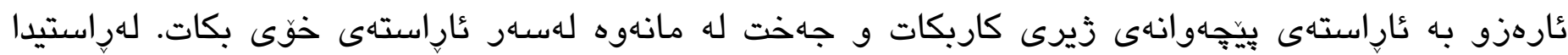




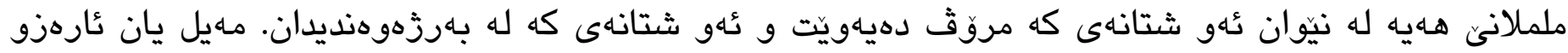

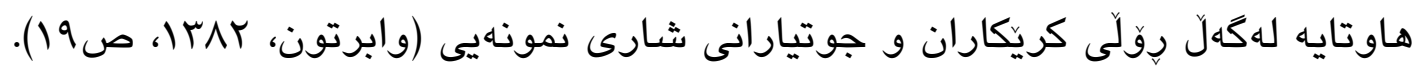

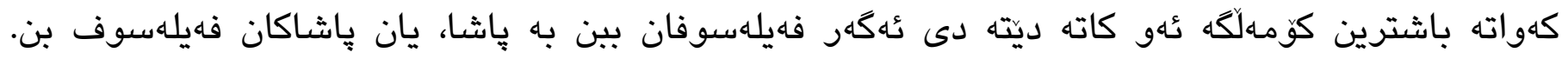
فهيلهسوف شهايدا و ئهويندارى زانينه. ئهويندار تهواوى ئهوينهكهى خوّش دهويت، فهيلهسوف ئهويندارى تهواوى زانينه و خوازيارى رِاستييه. لهبهرئهوه، تهنها فهيلهوفان دهتوانن داديهروهرى و ناداديهروهرى له يهك

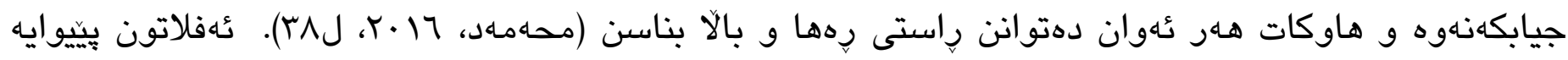

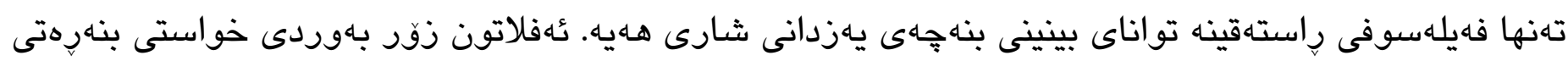
سياسهات دهستنيشان دهكات. واته سـروهرى ثـا فهيلهسوف ثُهوه دهخوازيّت كه بهتهواوى بنهبرى كهندهلّى

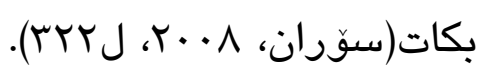

\section{r- بلهيومثلى ناكار و سياسلةت}

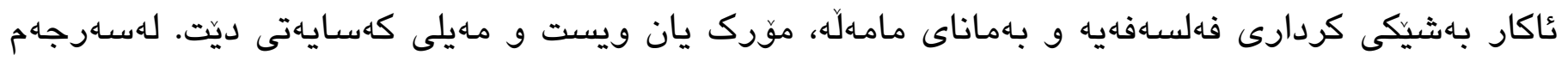

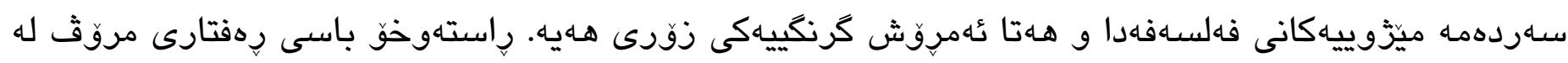

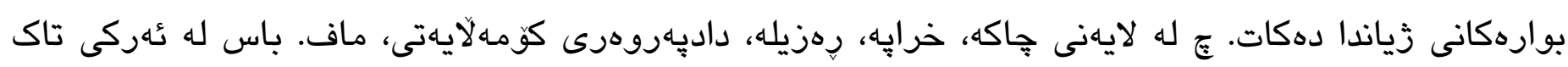

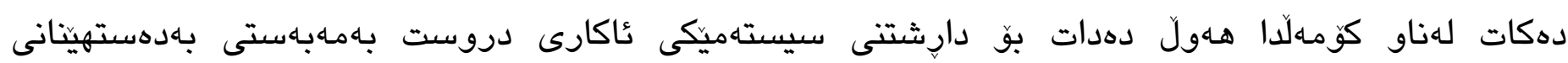

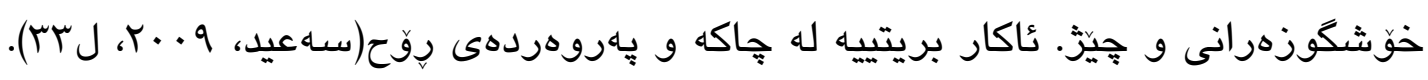

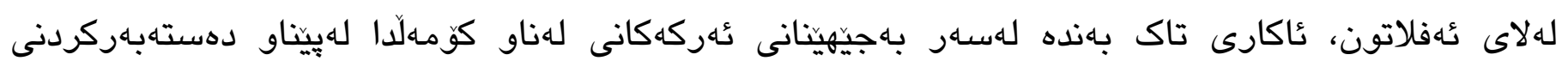

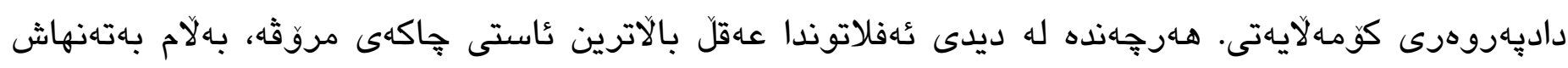

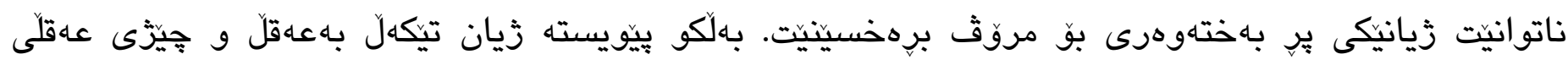

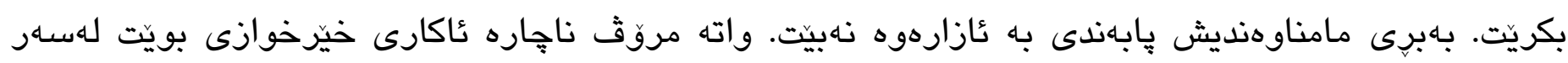

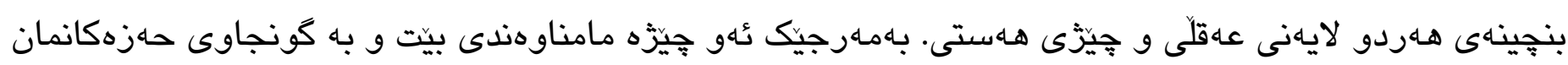

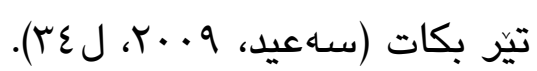

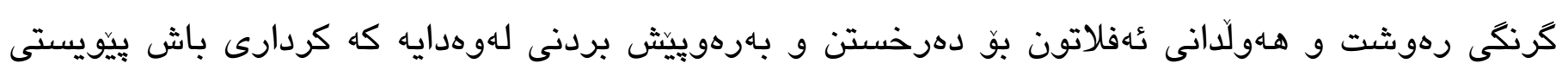

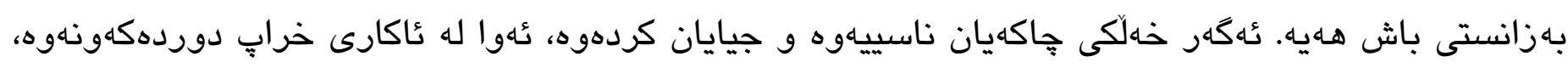

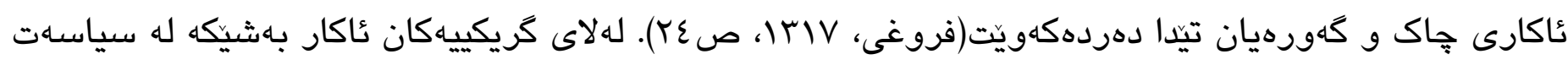

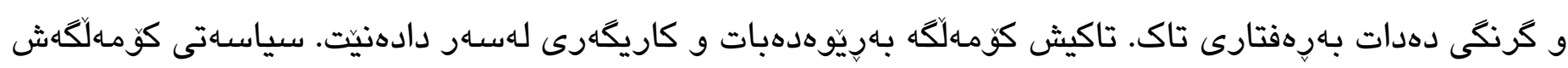

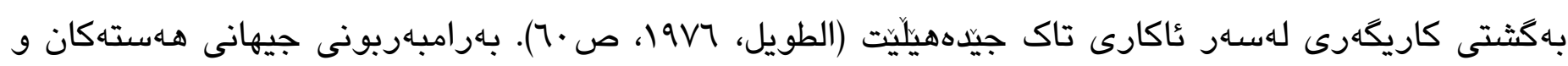
جيهانى ذيرى يان نيّوان ماده و شيّوه بـرامبهربونه له ناكاردا. بـجوّريّك كه مادهبوه به بناماى هـمو شتيكى

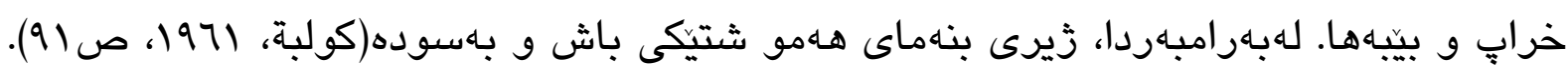

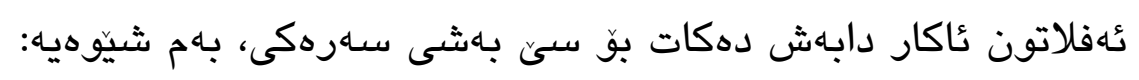


ا - كَهران بهدواى عاكاردا بهيلهى يهكهم كهرانه بهدواى جاكهدا.

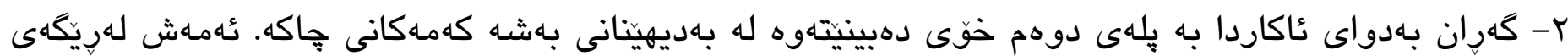
فهزيلهته بالآكانهوه لهلايهن تاكهوه بهديديّت.

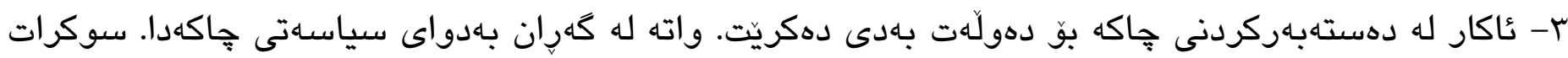

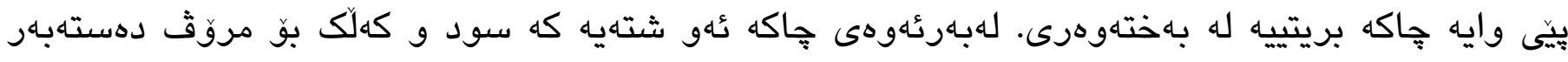
دهكات. ههروهها ئامانجى هامو كاريكى ئاكارى بريتييه له بهديهينانى بهختهوهرى. ئهفلاتونيش هاروهك

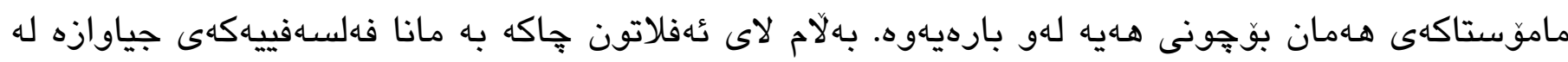

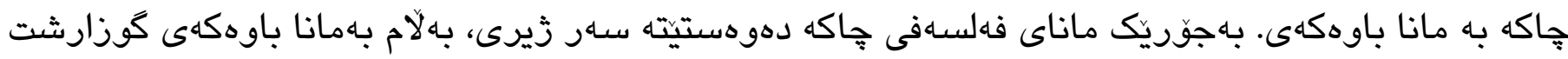

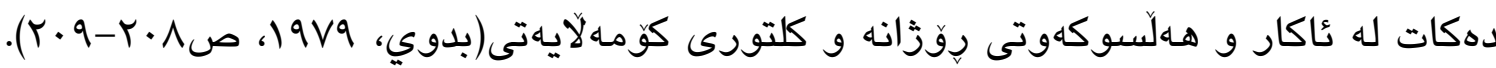

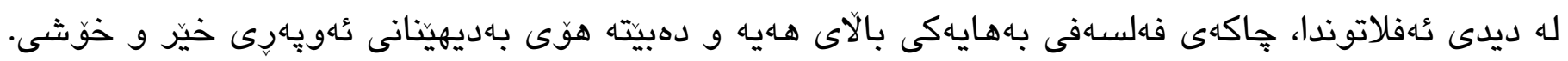

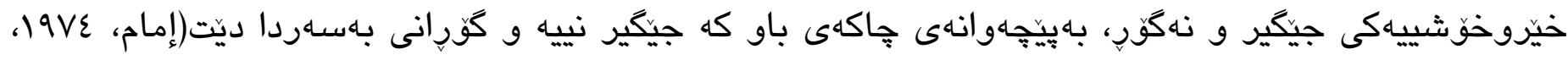

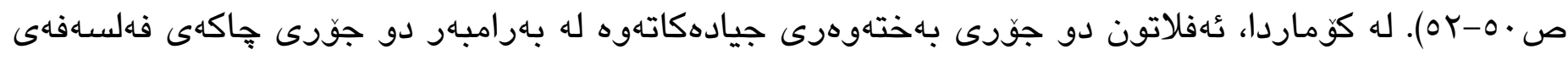

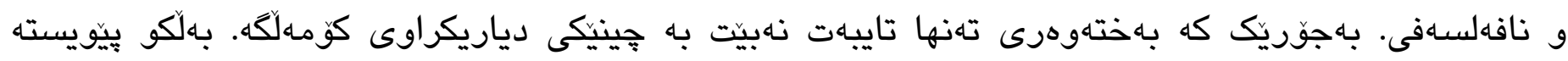

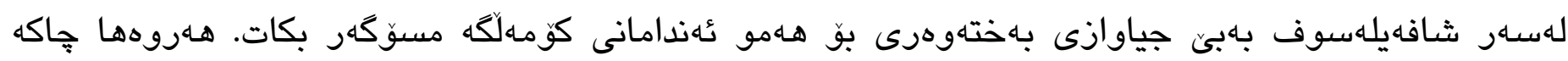

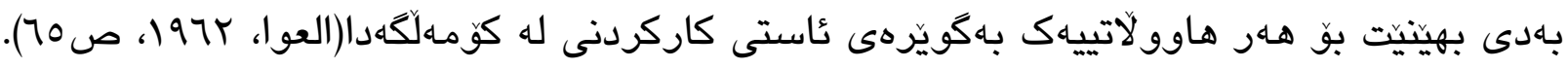

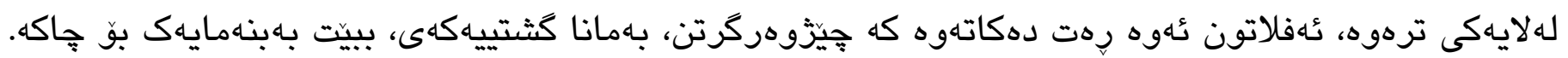

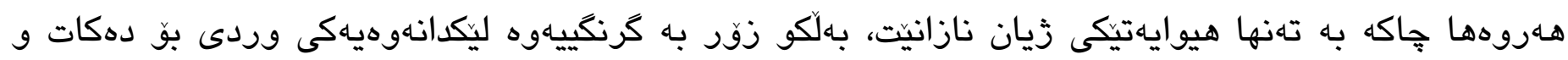

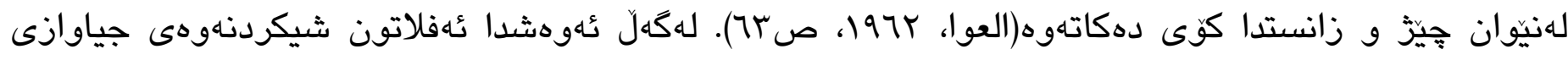

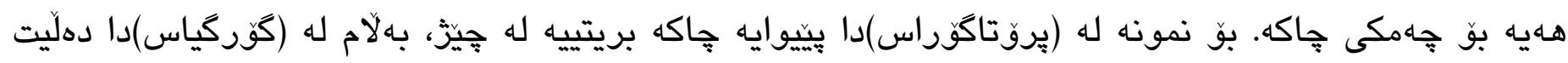

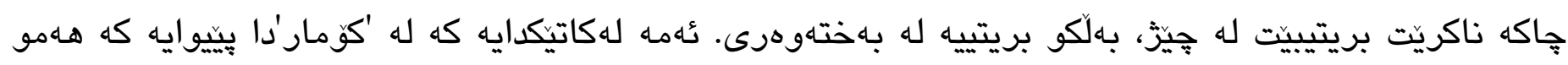

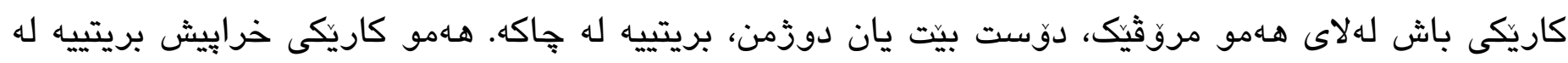

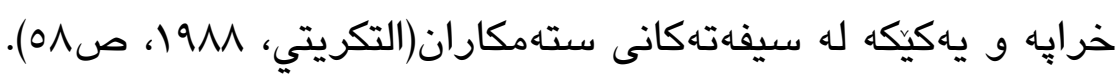

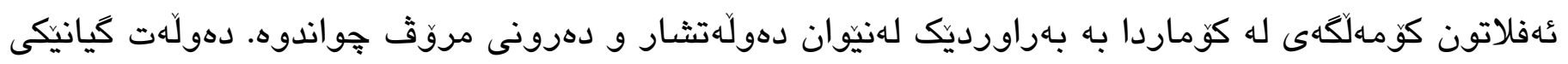

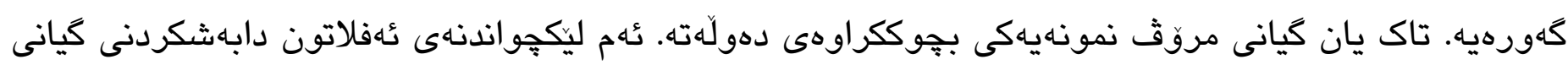

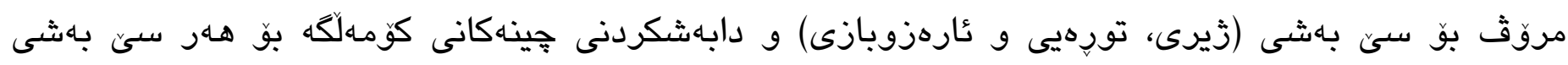

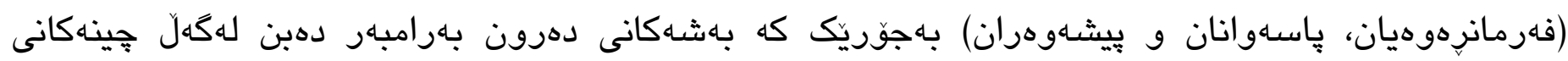

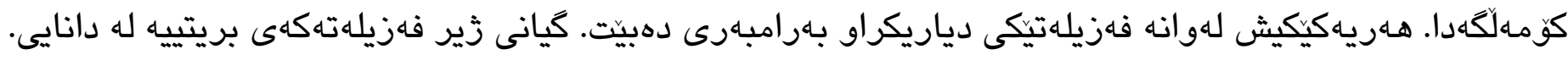

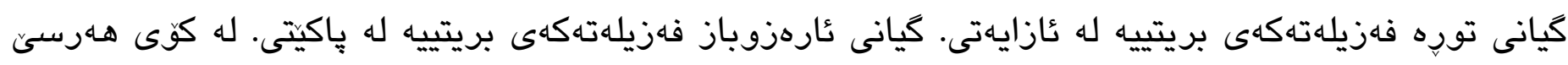

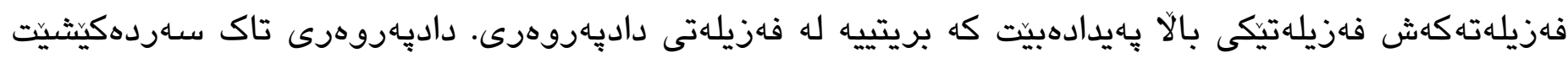




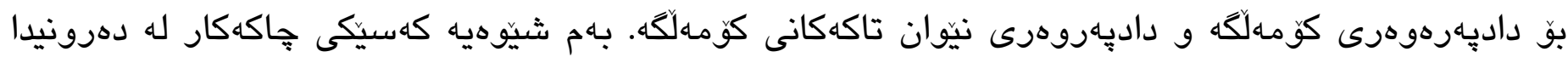

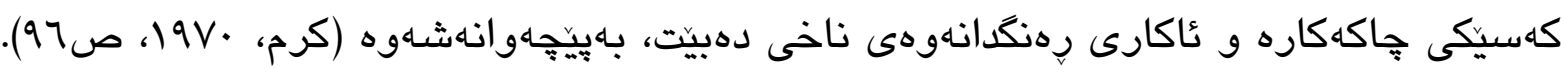

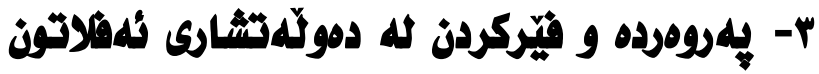

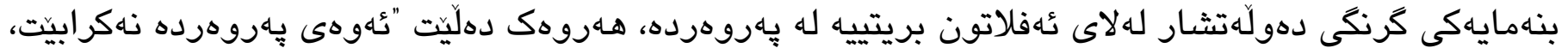

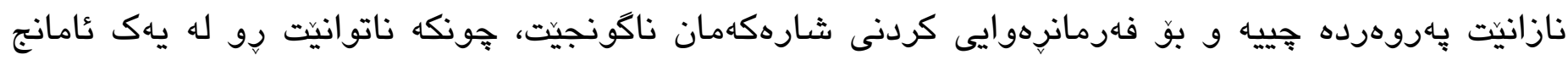

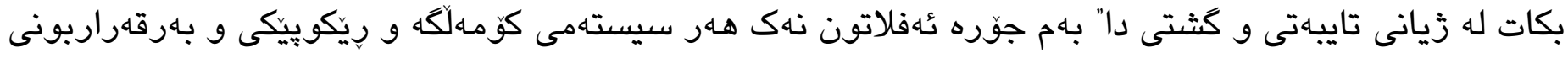

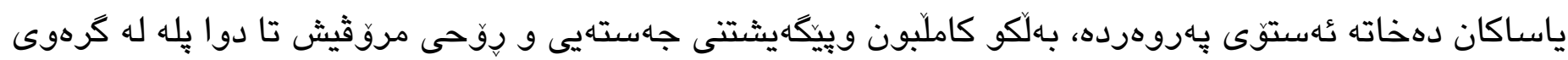

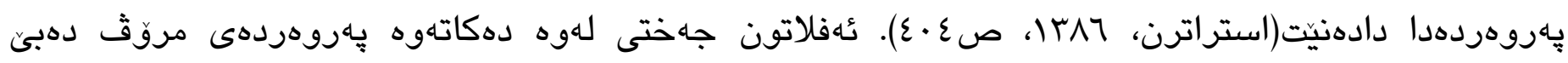

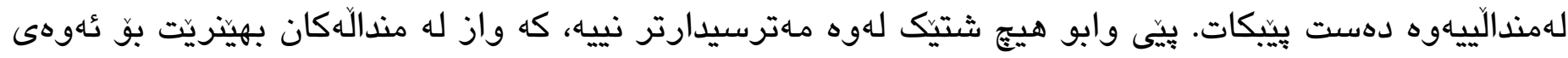

$$
\text { به هـهرماكى كاهورهبين (كويره، }
$$

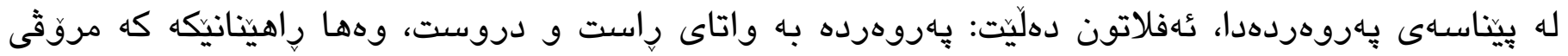
شـايسته و داديهروهر بينيته كايهوه. للم رِوهوه لهو باوهرهداين، پِروهرده بالآترين نيعماهتيكه، كه باشترين

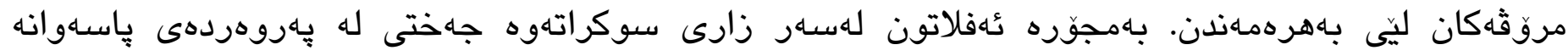

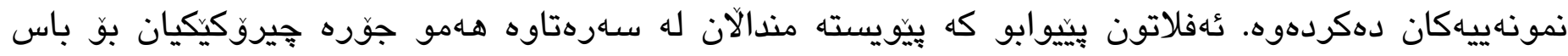

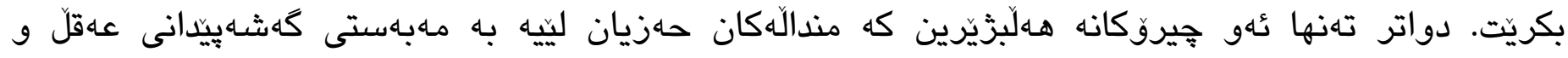

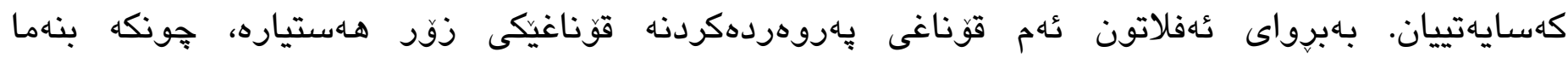

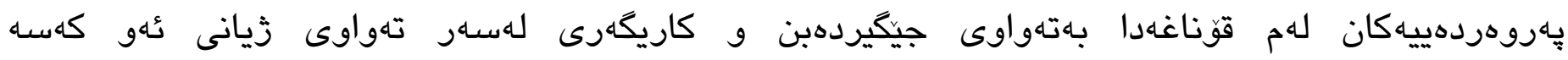

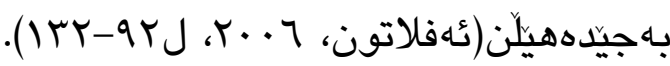

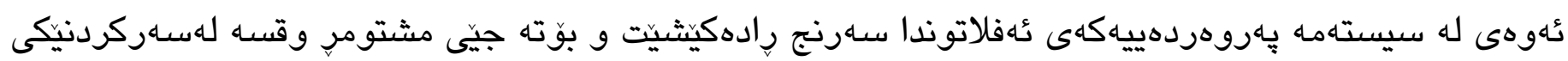
زوّر جهختكردنيهتى له سيستهمى كومهلآيهتى. واته دهبيت رِيّا بدريت باشترين دايك و باوكهكان زورترين

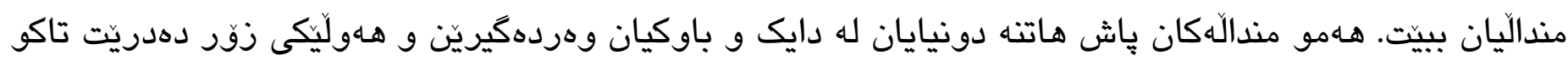
دايك و باوكهكان مندالهكانى خويان نهناسنهوه. ئهو مندالانهى كهم ئهندامن يان دايك و باوكيكى باشيان نييه له

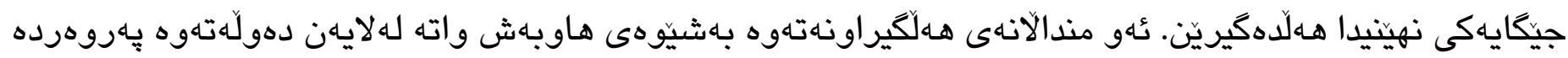

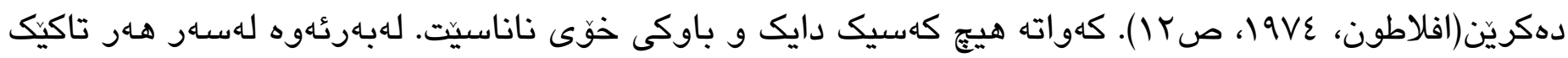
يِيّويسته ئهو يِياوانه بهاباوكى خُوى بزانيت، كه سالآنه دهتوانن بينه باوكى ئهو. لهبارهى دايك و خوشك و براوه

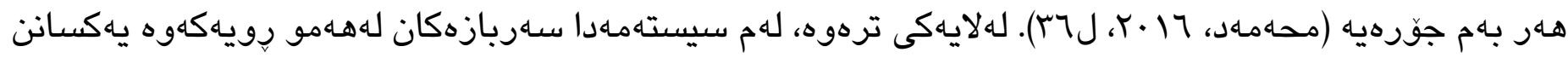

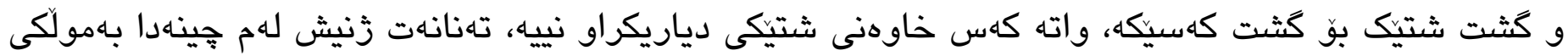

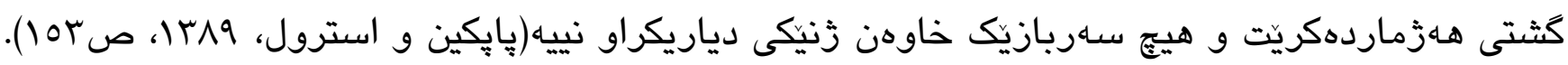
باهشيّوهيهكى كُشتى سيستهى يُروهردهى ئهلاتون دو لايهنى هـاهيه: 


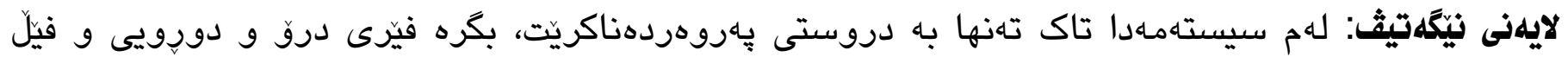
لهيهكتركردن و هـاهت به بهريرسياريتّى نهكردن دهكريّت. هـر له مندالييهوه جِيروكى خواوهندهانيان بوّ باس

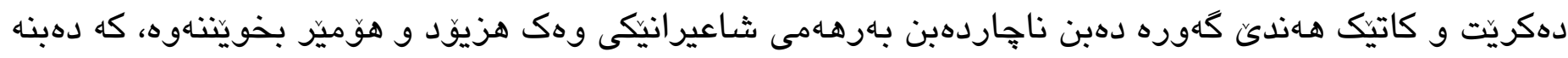

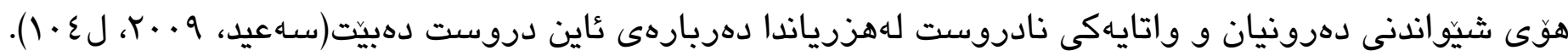

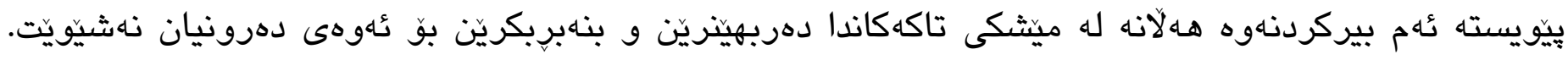
كهواته يهكهم هـهناو و بنهاما بوّ يهروهردهيهكى دروست جاكسازييه له بيروباوهره ئاينييهكان و بهديهينانى واتا

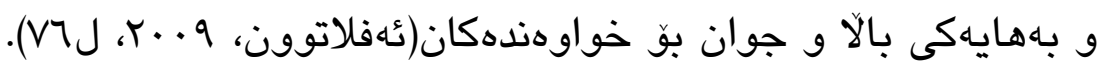

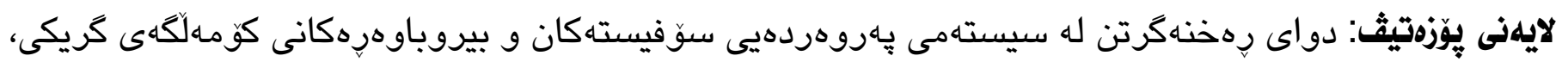

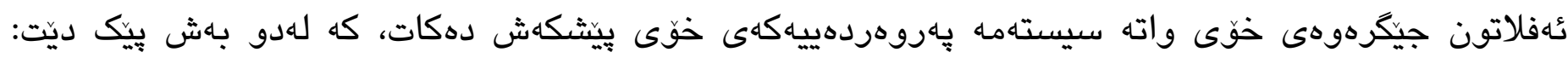
يهكهم: يهروهردهى روّحى: واته موسيقا. دوهم: يّروهردهى جهستهيى: واته وهرزش. يِّويسته ئهوه بكوتريّت، كه

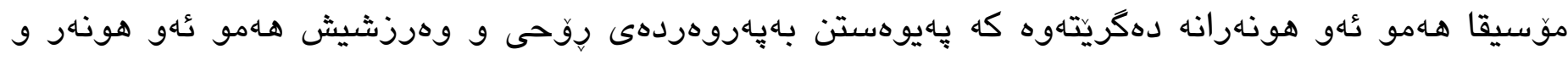

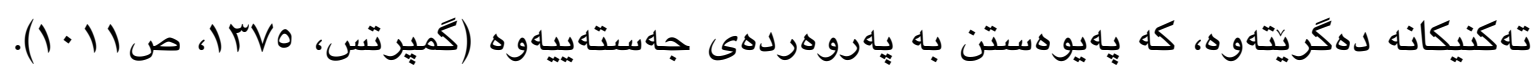

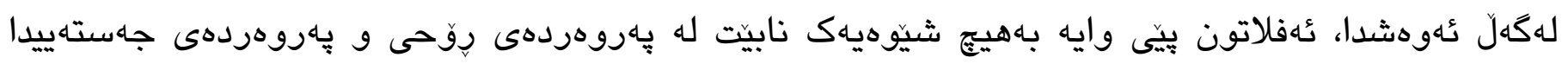
زيادهرهويبكريّت جهونكه "عَوانهى وهرزشى زوردهكهن درنده دهردهجن و ئهوانهى هوَنراوه و موّسيقاش دهخوينّن كهسانيكى زياد له يِيويست نهرم و نيانن. لهبهرئهوه، ئهلاتون دهلّيت "سادهيى له موّسيقا دهرون ذيرماهند دهكات

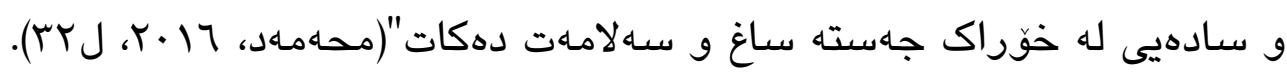

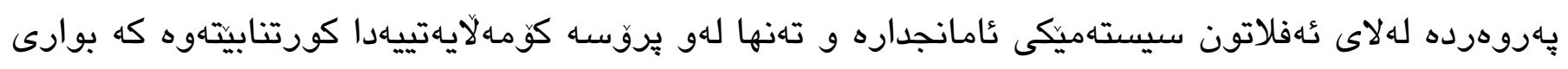

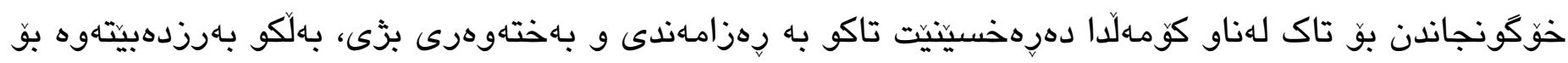

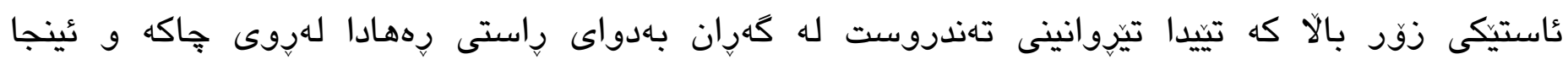

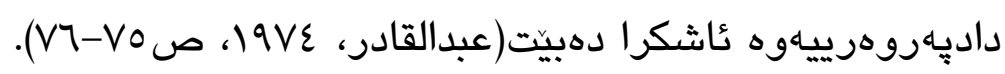

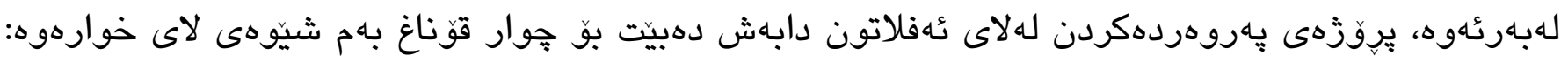

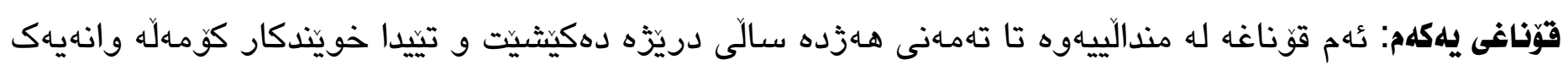
دهربارهى وهرزش و مؤسيقا و راهينان وهردهكريت. لهموسيقادا هوَنراوهى بهسود و جاك دهخوينريّت، كه

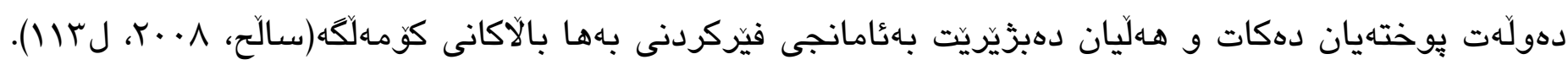

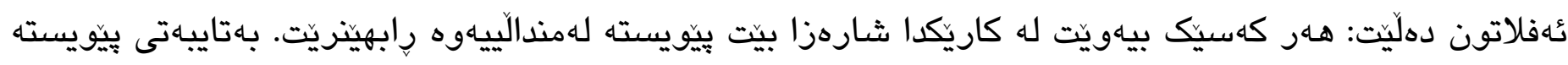

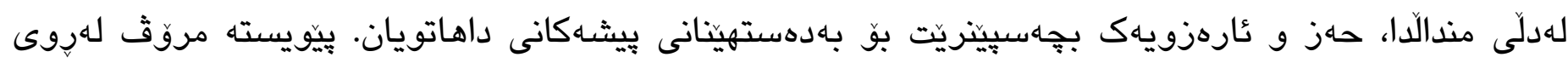

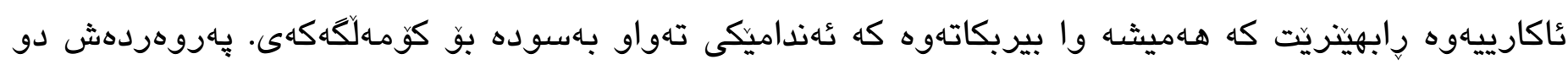

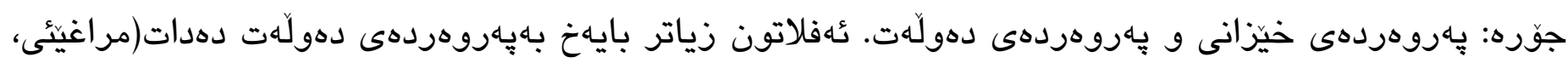




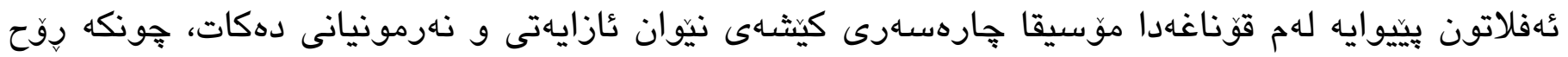

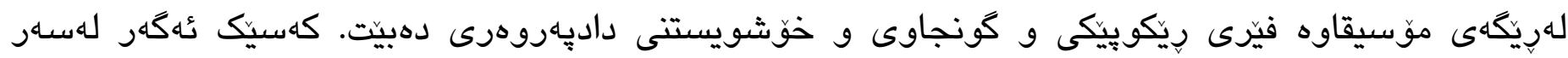

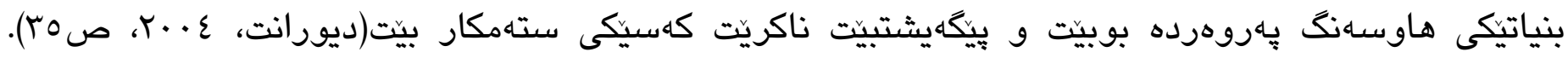

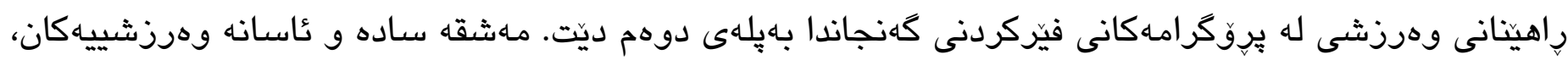

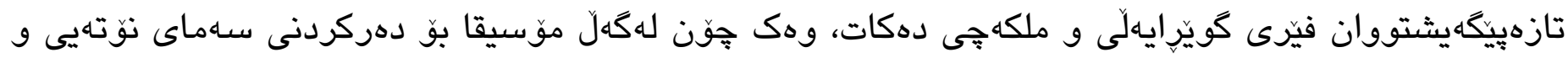

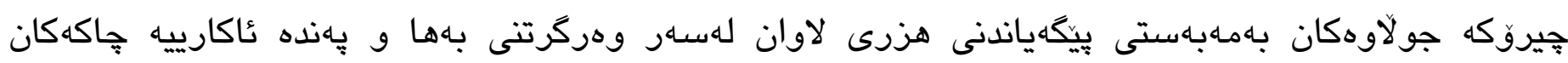

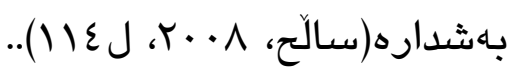

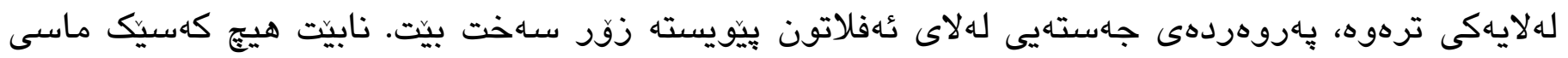

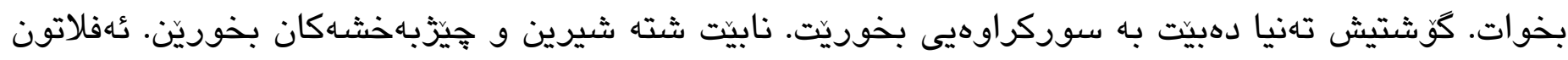

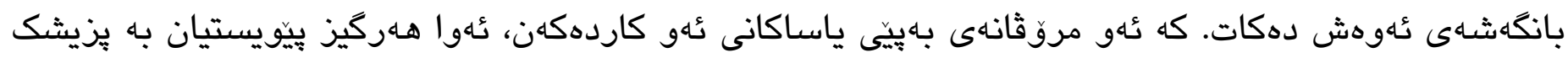

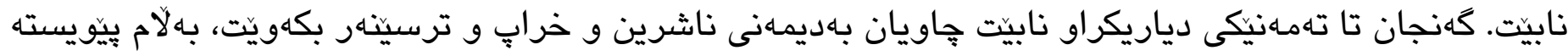

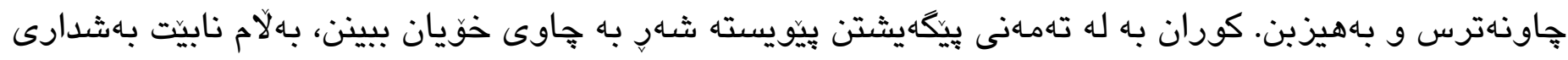

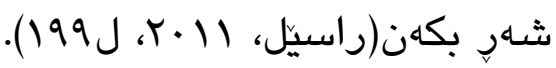

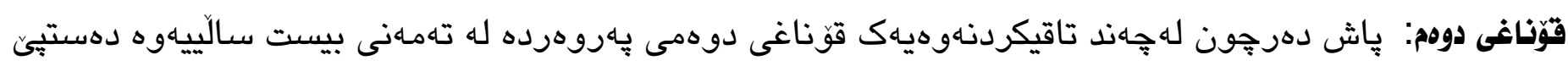

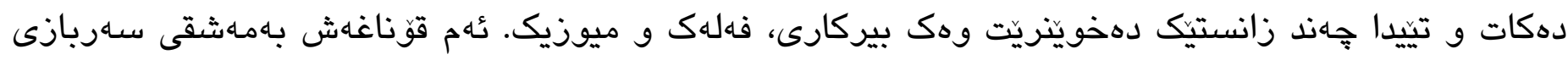

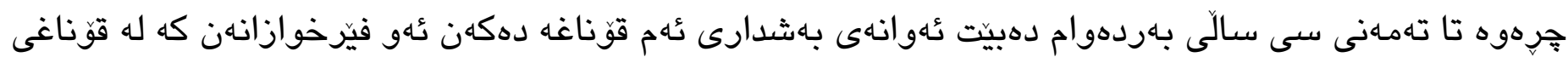

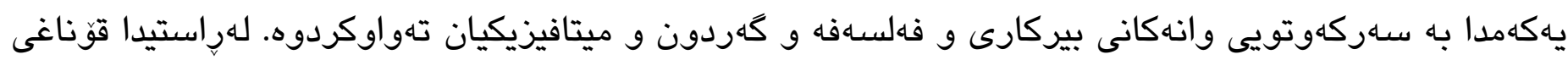

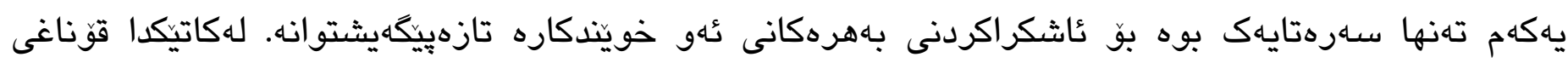

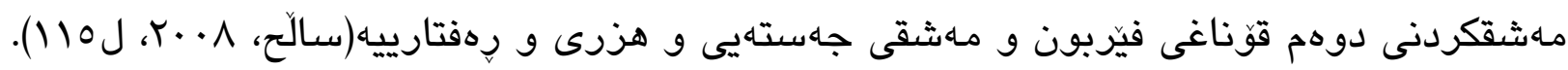

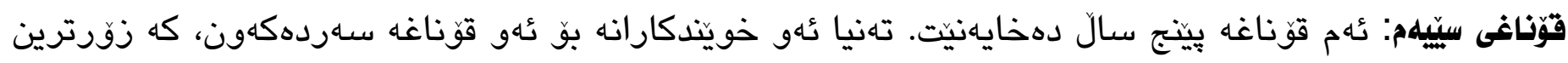

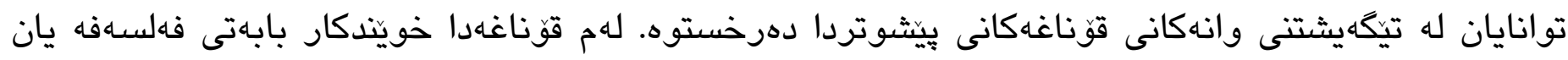

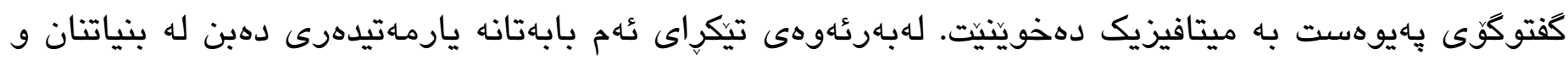

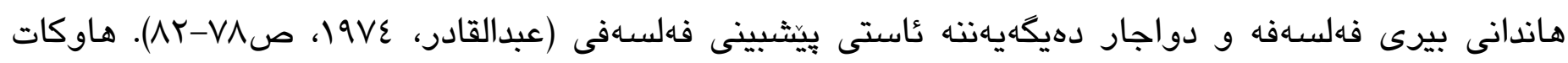

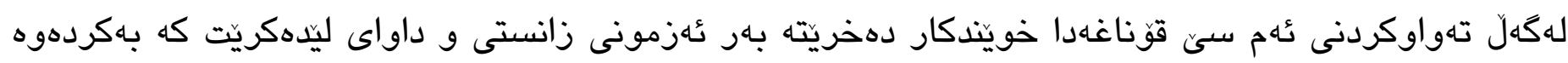

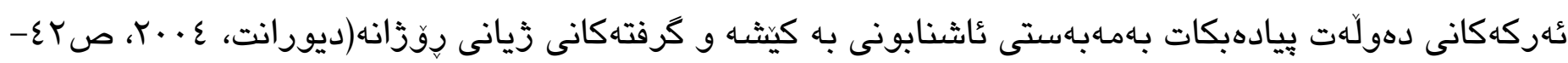

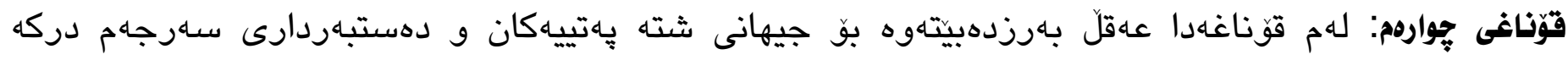

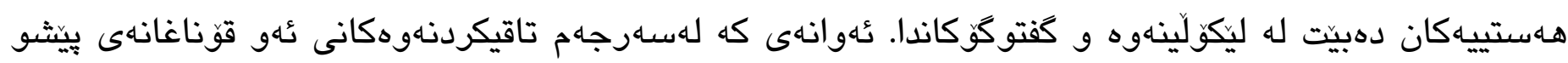

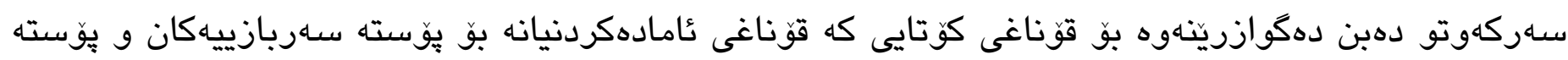




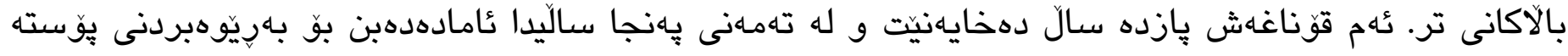

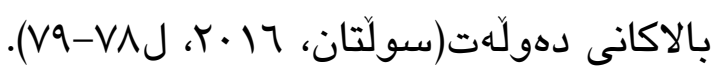

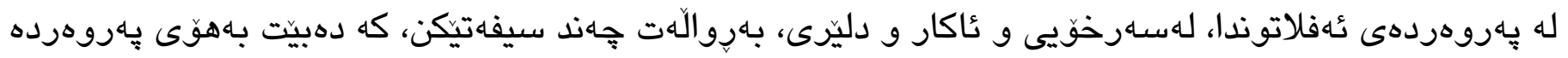

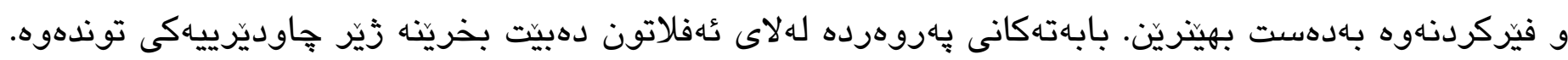

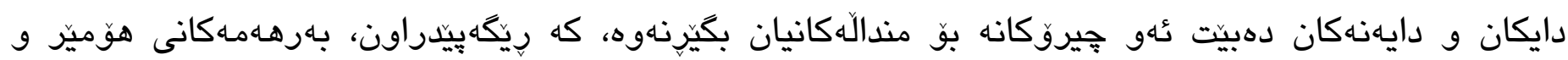

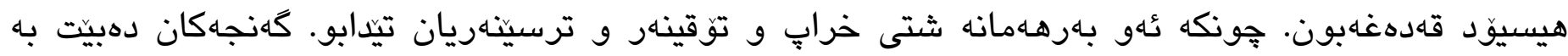

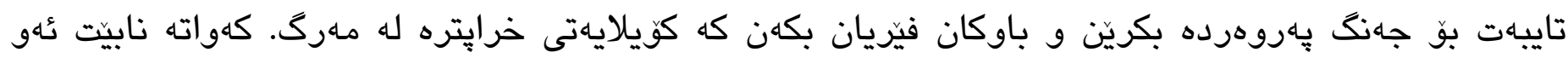

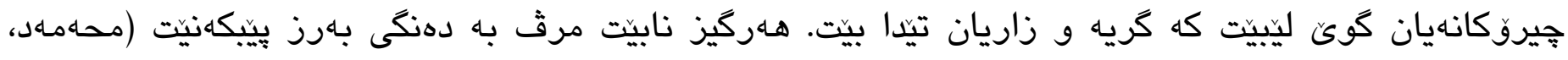
(r T.r...9

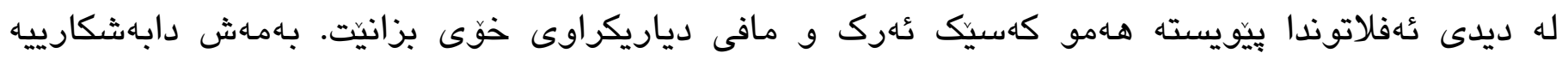

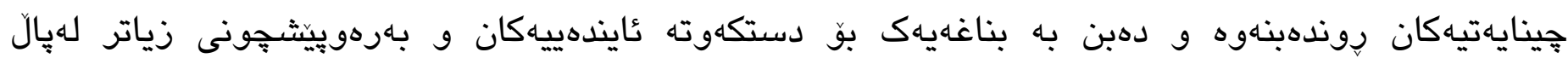

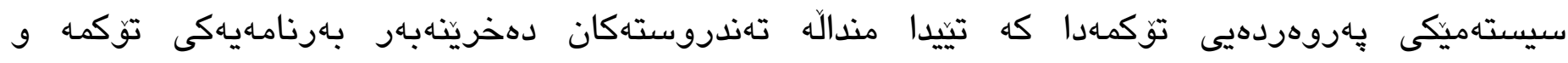

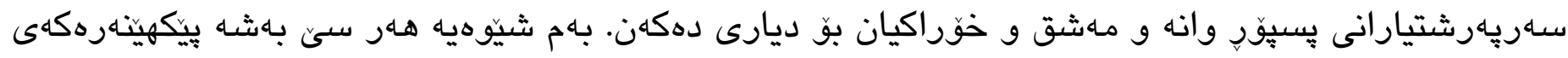

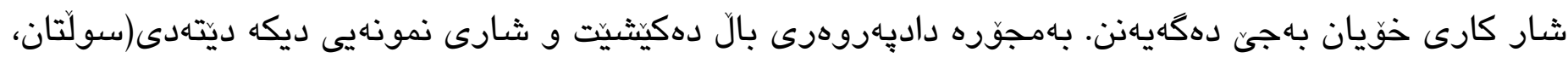
.(VN-VVJ، T. 17

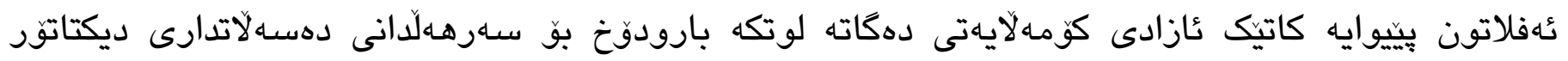

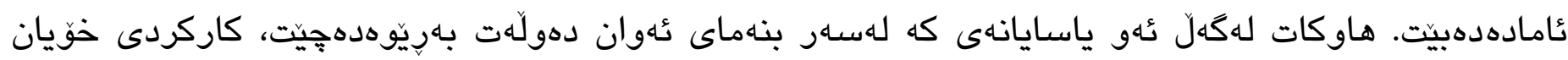
لهدهست دهدهن، دهسه لآتارى ديكتاتقور ياسا و ويستهكانى خوّى دادههينيتّ و ئازادى بيّسنور دهبيته هوَى ديلبون.

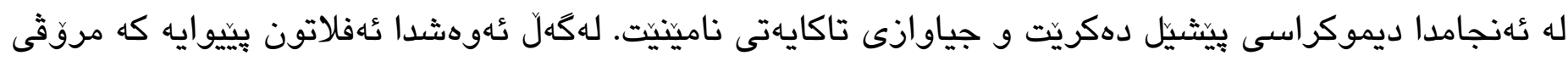

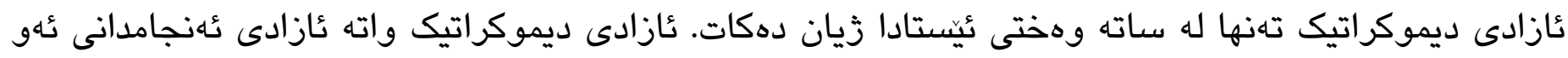

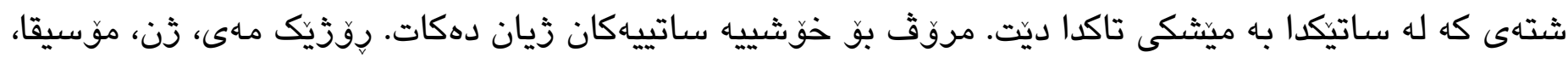

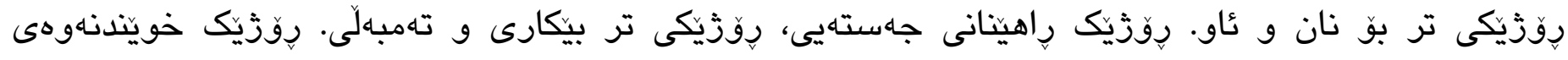

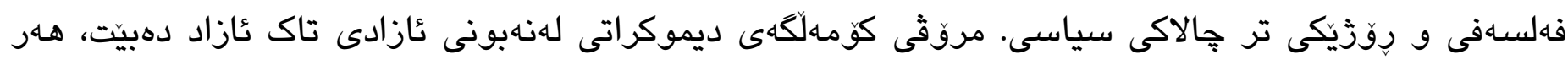

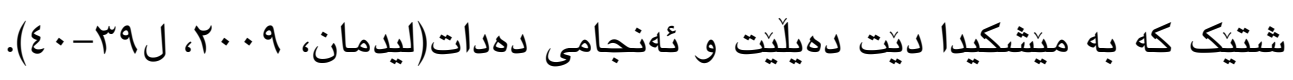

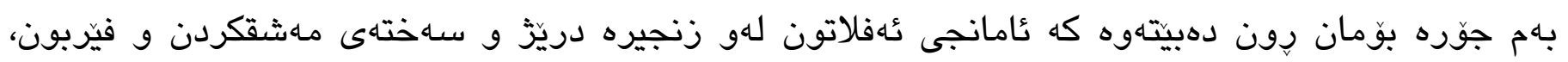

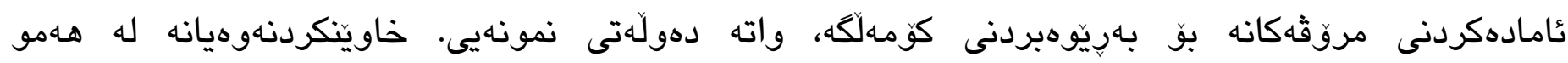

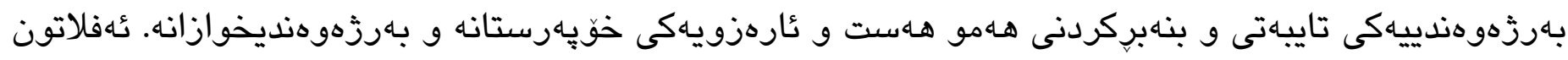

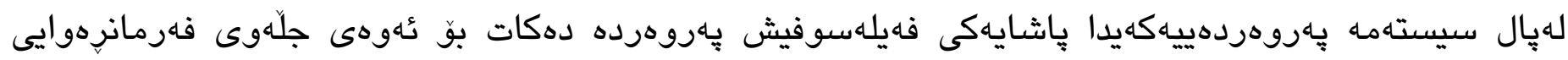

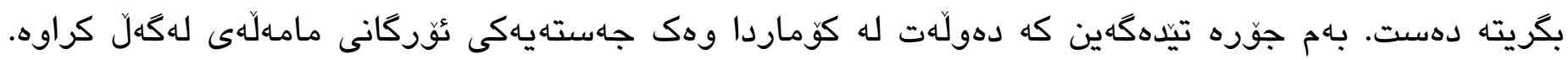




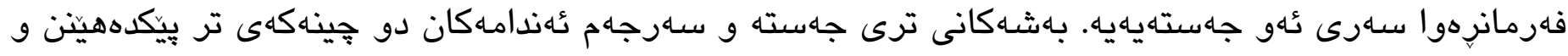

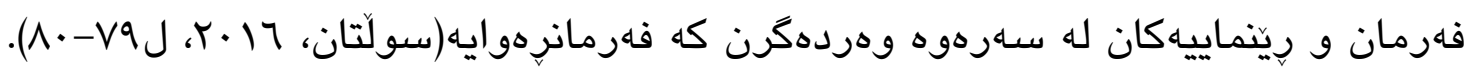

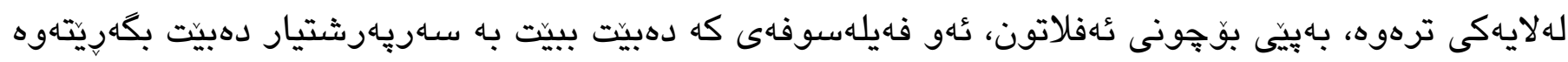
بوّ كُهالؤزياى ئهشكهوتهكه و له دهبيت خاوهنى داديهروهرى و ميهرهبانى و ييّت و خوازيارى فيّربونى زانست و خاوهن بيريّكى بههيز و

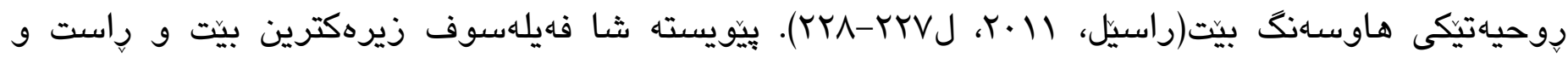

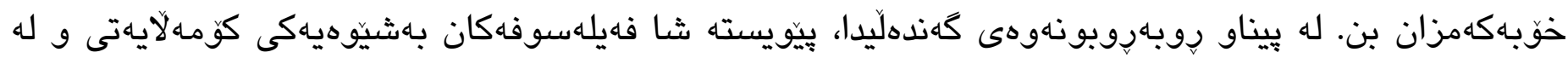

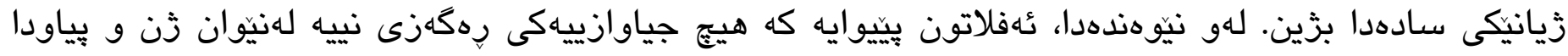

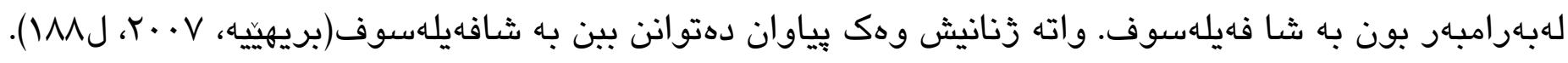

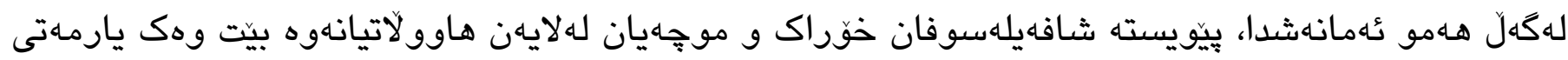

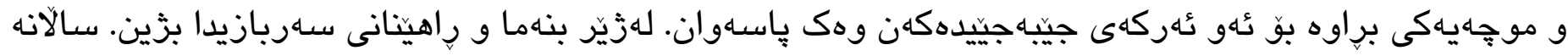

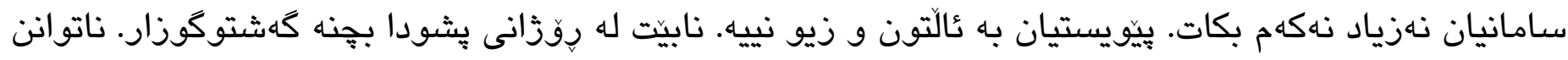

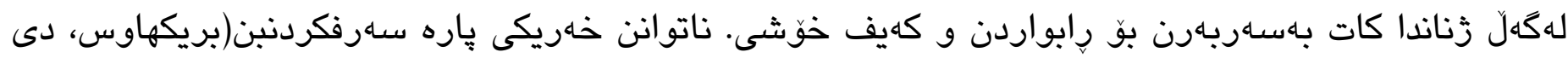

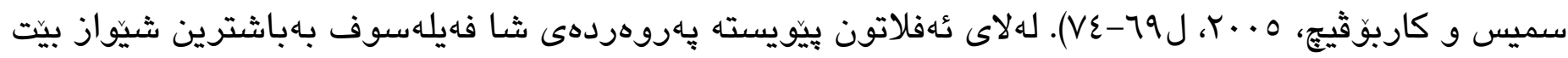

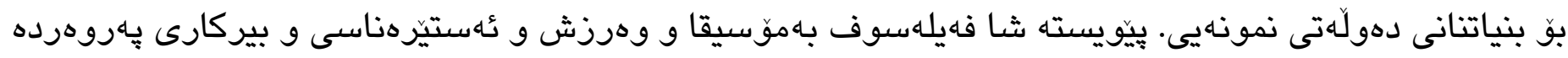

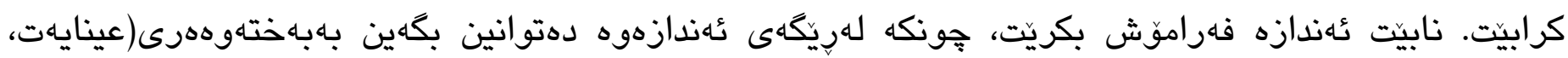

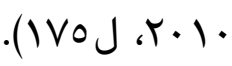

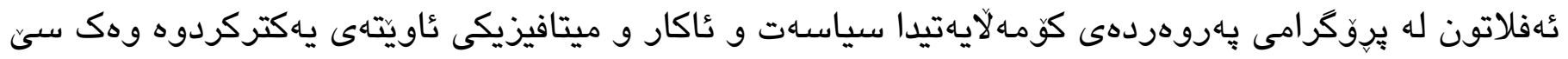

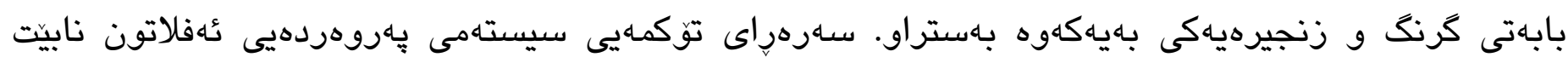

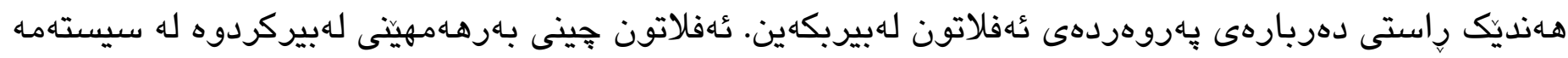

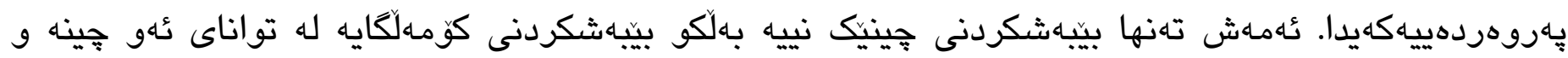

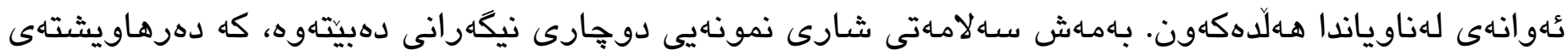

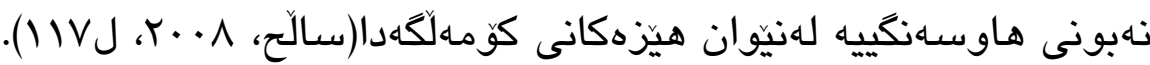

\section{ألهذجام:}

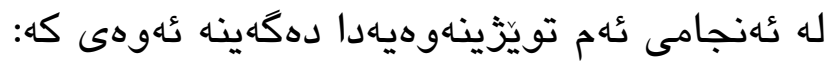

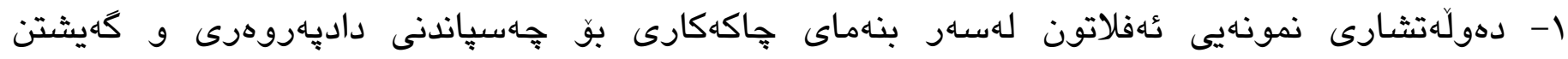

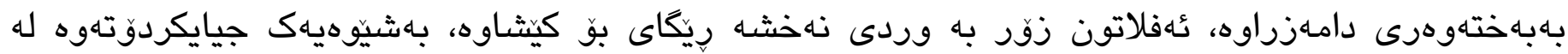

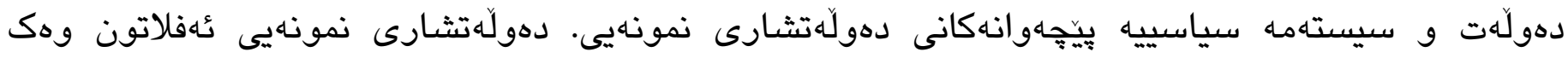
جهستهيهكى يهكگرتو وايه سهارجهم تئندامهكانى بهيهكهوه كاردهكهن بوّ بهدهستهينانى داديهروهرى و و 


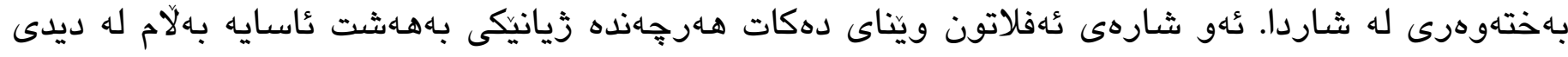
كئهلاتوندا هينانهكايهى لهسهر دهستى شـافهيلهوف ئهتهم نييه، بهتايبهت كاتيك تاكهكانى كومـالكَه لهسهر بناماى بهرزهوهندى هاوبهشدا و لهزيزر سايهى سيستهيكى سياسى توكمهدا كويبنهوه.

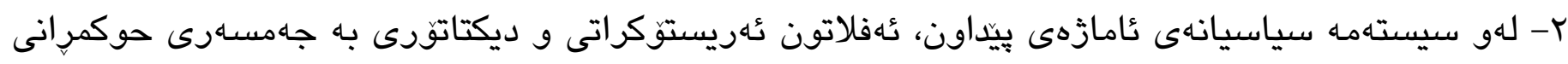

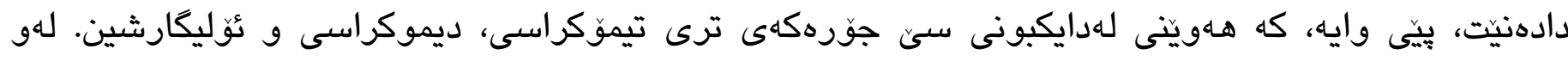
نيّوهندهشدا، كُهريستوكراتى باشترين جوّرى سيستهمى سياسييه له دهولَهتشاردا، جونكه لهلايهن فهيلهسوفانهوه

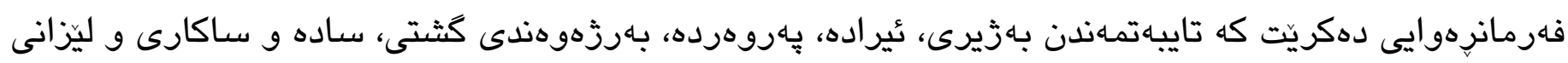

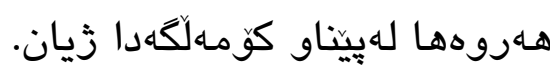

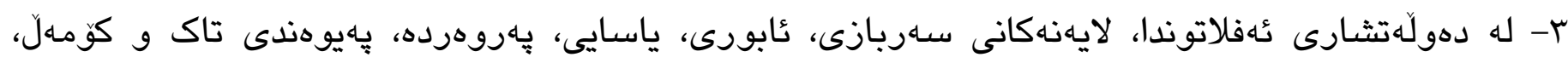

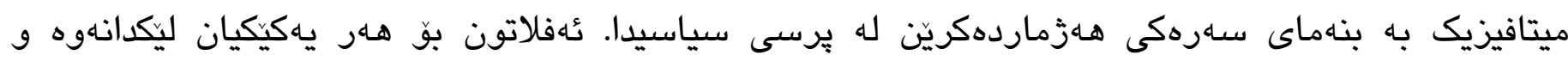

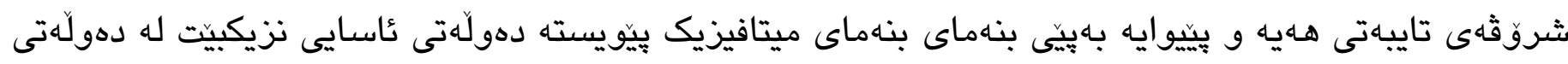

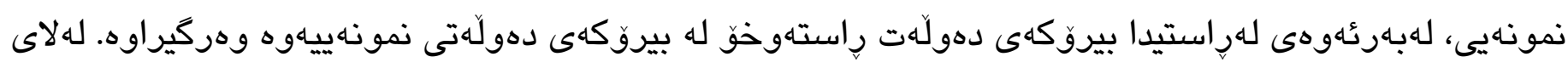

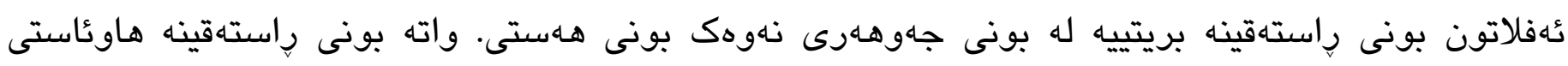

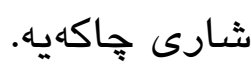

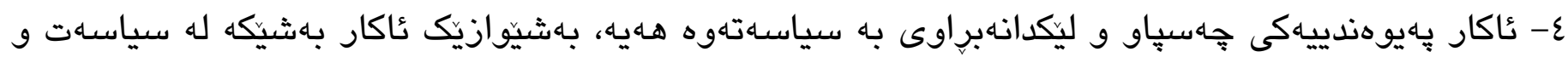

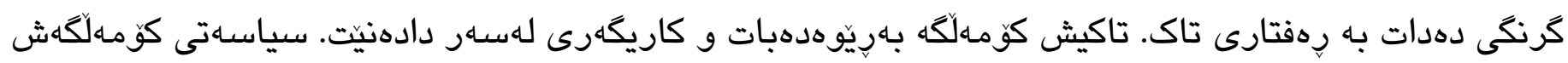

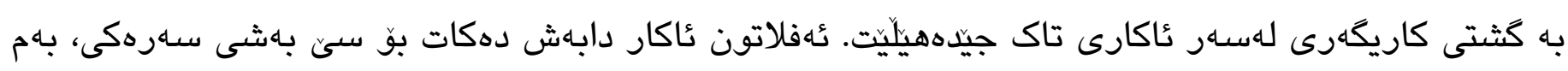

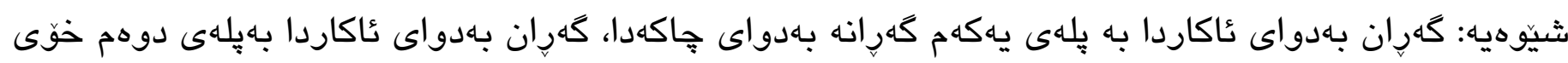

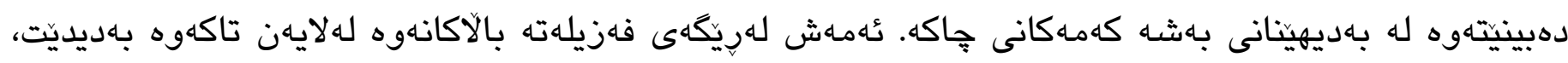

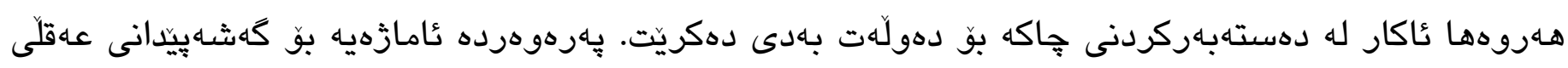

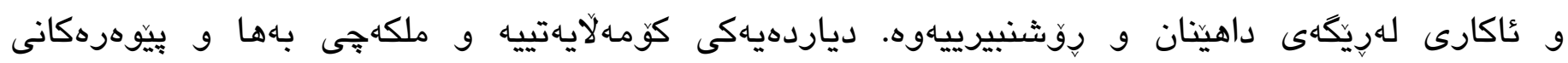
كاهشاسـاهندن و بـرهويِيش جونه.

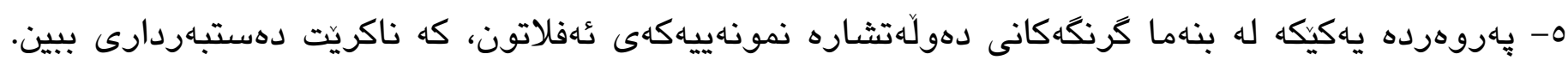

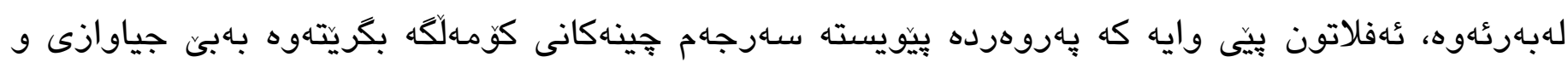

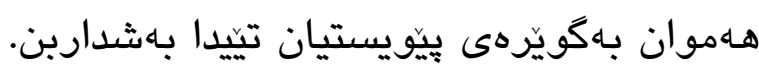

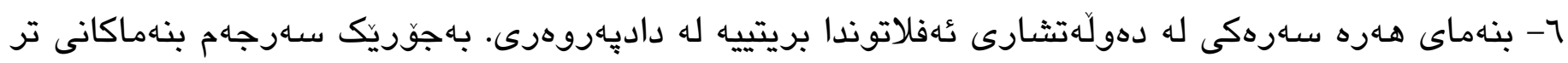

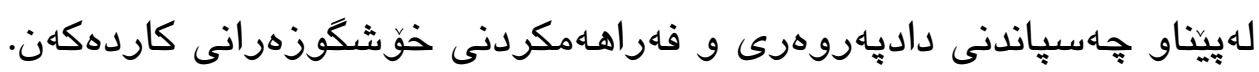




\title{
The Principles of The City-State in Plato's View
}

\section{Muslim Hassan Mohammed}

Department of Philosophy, College of Humanitarian Sciences, University of Raparin, Rania, Kurdistan Region, Iraq.

E-mail: Dr.muslimhasan2004@uor.edu.krd

\section{Zryan Hamza Aziz}

Department of Philosophy, College of Humanitarian Sciences, University of Raparin, Rania, Kurdistan Region, Iraq.

E-mail: Zryan.hamzaaziz@uor.edu.krd

\begin{abstract}
:
Plato's thoughts, as great Greek philosopher, are still counted as one of the best references in terms of political philosophy and are in practice in the world of politics. Plato owns a utopian state based on the foundation of justice and virtue. Plato's state, ruled by philosopher-kings, is characterized by having particular thoughts about the system of education.

Politics is vitally important within Plato's philosophy. It is regarded as means of planning his utopian city. Plato believes that political systems can be classified, in accordance to their ruling type, into aristocracy, timocracy, oligarchy, democracy, monarchy and dictatorship. Among them, Plato believes that aristocracy is the best since it's practiced by a philosopherking.

Plato in his ideal state refers to metaphysics as an important basic of his utopian city. Plato's view is that the ideal state can only be cherished in the life of hereafter, though those in power may be able to find some sort of the ideal life in this world. The philosopher-kings, on the other hand, are able to practice such an ideal life in this world. In Plato's view, any sort of change happening in the world from the perfection towards the imperfection and weakness. This is due to the unstable feature of the world that never stays constantly. Only God is characterized by stableness and mortality.

Plato thinks that 'ethics' is one of the practical fields of philosophy which shows the will of any human being that depends on performing the duty of individuals in the society to establish social justice. Plato states that education refers to the right preparation of human beings to suit the world of justice. He sees the education as the highest virtue. Plato repeats that all the social city-state classes have to get the proper education formed in certain phases based on the age of the citizens.
\end{abstract}

Keywords: City State, Authority, Philosopher-King, Metaphysics, Education. 


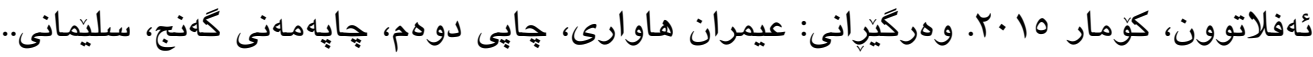

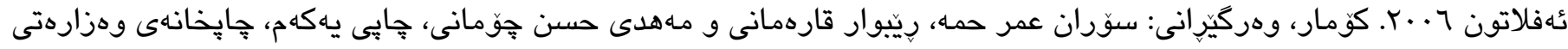

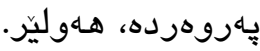

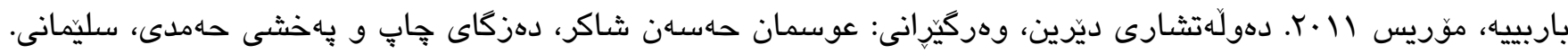

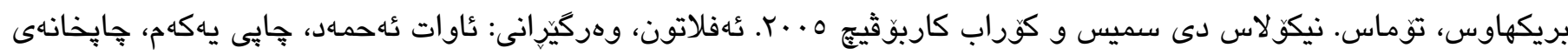
سيما، سليمانى.

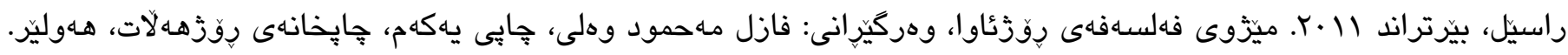

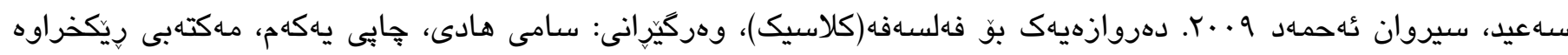
ديموكراتيهكانى ى،ن،ك، سليّمانى.

سالح، غانم محهمهد ^..r. بيرى سياسى كون و ناوهراست، وهركيّرانى: سهلام كهريم على، جايى دوهم، جايخانهى هيّمن، سكايدسادق.

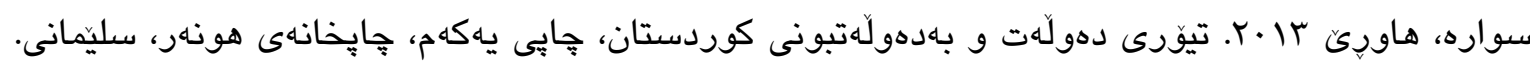

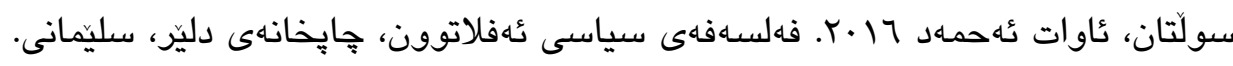

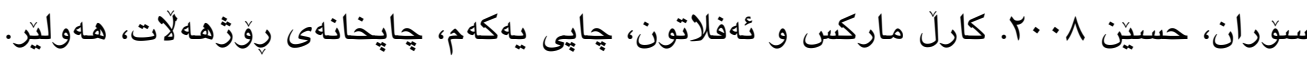

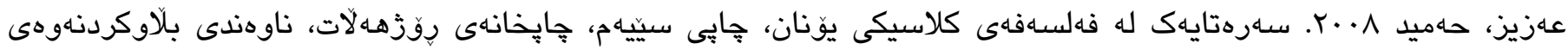
ئاويَر، هـوليَّ.

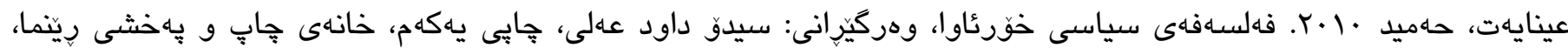
سلينمانى.

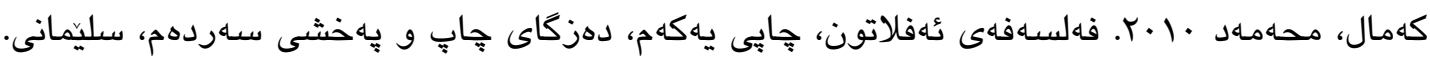

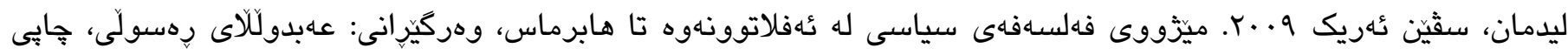
ياككهم، جايخانهى جوارجرا، سليّمانى.

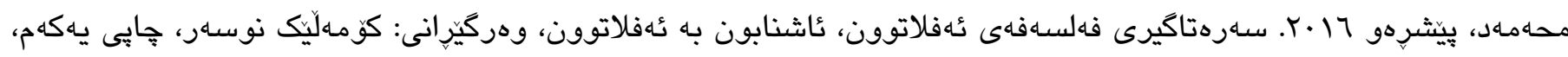
دهزكاى ئايديا بو فكر و ليكولِينهوه، جإيخانهى دليّر، سليّمانى. 


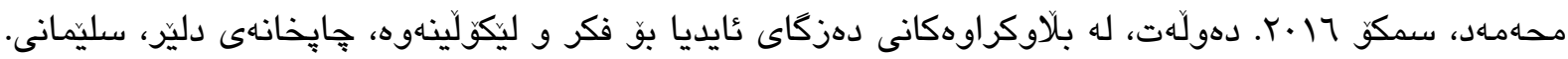

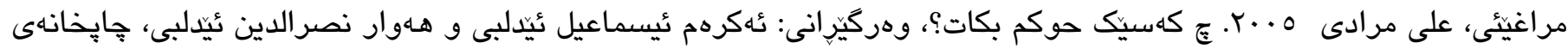
زانكوى سـه لاحهدين، هـوليّر.

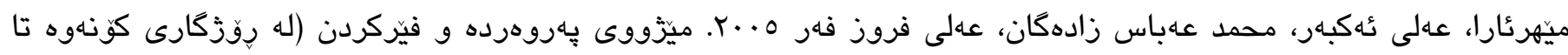

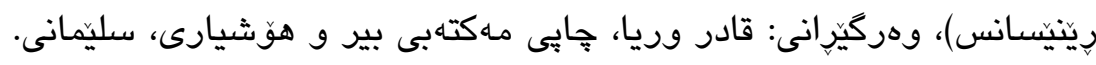

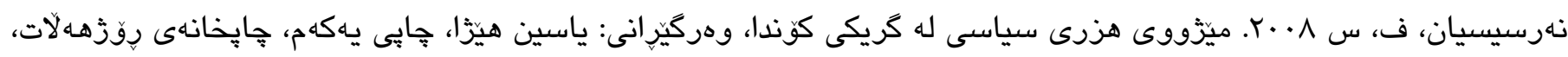
هـاهوليزر.

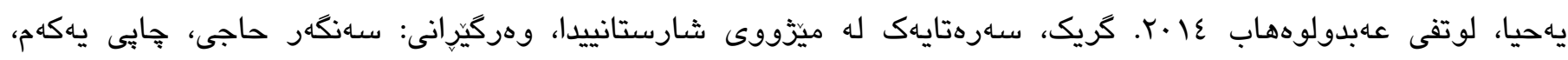

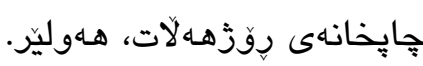
افلاطون ع19 19. فيدون، ترجمة: على سامى النشار و عباس الشربينى، طَ، دار المعارف، القاهرة. إمام، عبدالفتاح امام عV19 ـ محاضرات في الفلسفة و الأخلاق، دار الثقافة للطباعة و النشر، القاهرة. الأهواني، احمد فؤاد ال197ـ افلاطون سلسلة نوابغ الفكر الغربي، ط؟، دار المعارف، القاهرة. التكريتي، ناجي 191 ا. الفلسفة الاخلاقية الافلاتونية عند المفكري الاسلامي، ط؟، دار الشؤن الثقافية العامة 'افاق عربية'، جامعة كاليفورنيا، الولايات المتحدة الامريكية.

$$
\text { الجبر، محمد r . . r. الاخلاق في الفلسفة اليونانية، طا ، دار الينابيع، دمشق. }
$$

السيد، محمود V . . r. التأريخ اليوناني و الروماني، ط ا ، مؤسسة شباب الجامعة، الأسكندرية. الطويل، توفيق 1977 فلسفة الاخلاق نشأتها و تطورها، دار الهضية العربية، بدون مكان. العوا، عادل r 197.المذاهب الأخلاقية عرض و نقد، جا، طץ، جامعة دمشق، دمشق.

الناصري، سيد احمد علي 1977 ـ الإغريق، تأريخهم و حضارتهم من حضارة كريت حتى قيام امبراطورية اسكندر الأكبر، طץ، دار الهضة العربية، القاهرة. بدوي، عبدالرحمن 19v9 ـ افلاطون، وكالة المطبوعات، الكويت، القلم، بيروت. توشار، جان إ191. تأريخ الفكر السياسي ، جا ، ت: علي معتلد، طا ، الدار العالمية للطباعة و النشر و التوزيع، بيروت. حسين، عاصم احمد 1991 ـ المدخل الم تاريخ و حضارة الاغريق، ط ا ، مؤسسة الأسراء للنشر و التوزيع، القاهرة. حمدي، فاتنة جميل r 199 ـ الميتافيزيقا، بحث مقدم للتفرغ العلمي، جامعة بغداد، كليية الآداب، بغداد. خليفة، حسن 19 19. تاريخ النظريات السياسية و تطورها، طا ، المطبعة الحديثة، القاهرة. 
زكريا، فؤاد 0 . . r. دراسة جمهورية افلاطون، ط ا، ج ا ، دار الوفاء للدنيا الطباعة و النشر - الاسكندرية.

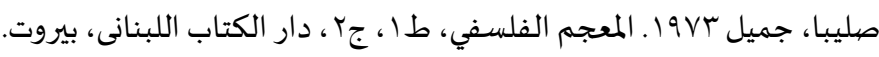
عبدالقادر، علي احمد ع 19 ا ـ مقدمة في النظرية السياسـة، مطبعة الكيلاني، القاهرة. عكاشة، على ، د. شحادة الناطور، د. جميل بيضون ـ 199 ـ اليونان و الرومان، ط ا ، دار الأمل للنشر و التوزيع، اربد، ،ع. فهمي، محمود 1999 . تأريخ اليونان، تقديم: الدكتور محمد زينهم محمد عزب، ط ا ، مكتبة و مطبعة الغد، القاهرة. كرم، يوسف . 19v. تاريخ الفلسفة اليونانية، مكتب دراسات الفلسفية، طه، دار المحرر الأدبي، مصر. كولبة، ارفك الجا9 ـ المدخل الى الفلسفة، نقله الى العربية و علق عليه ابو العلا العفيفي. لجنة التأليف و الترجمة و النشر، طب، القاهرة. مرحبا، محمد عبد الرحمن . . . r. من الفلسفة اليونانية الى الفلسفة الاسلامية، ط ا ، عويدات للنشر و الطباعة، بيروت. مصطفى، ممدوح درويش و السايح، ابراهيم 1991. مقدمة في تأريخ الحضيارة الرومانية و اليونانية، طا ، المكتب الجامعي الحديث، الإسكندرية. وايتهيد، الفريد نورث: مغامرات الأفكار (عرض فلسفي رائع للأفكار و الحضارات)، ت: انيس زكي حسن، مراجعة: محمود الأمين، عبدالرحمن خالد القيسي، مكتبة الحياة، طץ ، بالإشتراك مؤسسة فرانكلين للطباعة و النشر، بيروت - نيويورك. استراترن، بِل 1/1 ا اشنايى با افلاطون، ترجمة: مسعود عليا، جابٍ ششم، نشر مركز، تهران.

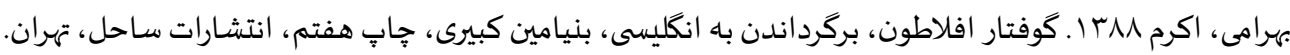
بورمان، كارل 0Vا I . افلاطون، ترجمة: محمد حسن لطفى، جاب اول، انتشارات طرح نو، تهران.

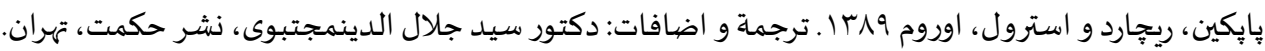

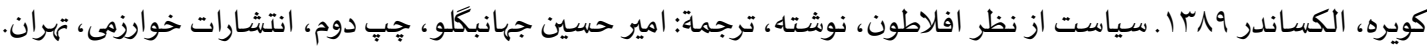
كميرتس، تئودور YYO I ـ متفكران يونان، ترجماة: محمد حسن لطفى، خوارزمى، ج ا-Y تهران.

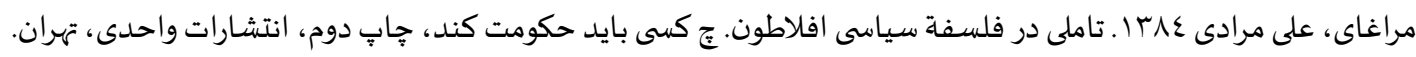

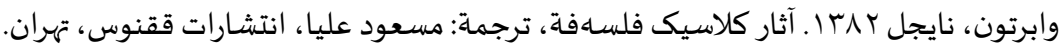

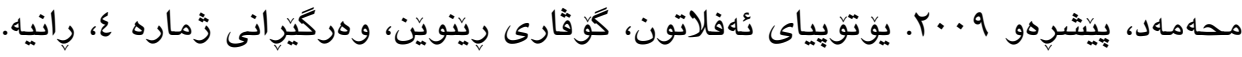


Aristotle, \& Ross, W. D. 1981. Aristotle's Metaphysics, $18^{\text {th }}$ ed, Oxford, Clarendon Press.

Barker, Ernest 1960. Greek Political Theory, Methuenand, Co, Ltd, London.

Bloom, Allan 1968. The Republic of Plato. New York, Basic Books.

Burnyeat, M. F. 1997. Culture and Society in Plato's Republic, The Tanner Lectures on Human Values, Harvard university, MA, The USA.

Cary, M. and Haaroff, T.J 1961. Life and Thought in the Greek and Roman World, New York.

Ferrari, G.R.F 2000. (ed.), Griffith, Tom (trans.). Plato. The Republic, Cambridge, Cambridge University Press.

Finley, M. I. 1966. The Ancient Greeks, $1^{\text {st }}$ ed, Pelican ed. The USA.

Hugh, Benson 1992. Socrates and the beginning of moral philosophy, Oxford university Press, New York.

Kemerling G. 2011. Plato, The State and the soul, The Philosophy pages, available from: http://www.philosophypages.com/hy/2h.htm Accessed [Dec 30, 2019].

Pomeroy Sarah B., et al (2005) A Brief History of Ancient Greece: Politics, Society, and Culture, New York, Oxford University Press, Inc.

Reeve, C.D.C 2004. Plato. The Republic, Indianapolis, Hackett.

Shorey, Paul. Plato, 1937. Republic (2 vols. Loeb, 137-). This translation includes an introduction and notes. Spielvogel, Jackson J 2005. Ancient Civilizations, Discovering Our Past, McGraw Hill/Glencoe; Student edition, Ohio, the USA. 